A NATUREZA FotográficA dA ARTE 
UNIVERSIDADE DE SÃO PAULO

ESCOLA DE COMUNICAÇÕES E ARTES

PROGRAMA DE PÓS-GRADUAÇÃO EM ARTES VISUAIS

\section{A Natureza Fotográfica dA ARTE}

Catalogação na Publicação
Serviço de Biblioteca e Documentação
Escola de Comunicações e Artes da Universidade de São Paulo
Feliciano, André
A Natureza Fotográfica da Arte / André Feliciano. - São Paulo:
d.m.
Feliciano, 2013. 150 p. : il.
Dissertação (mestrado) -- Escola de Comunicações e Artes /
Universidade de São Paulo.
Orientador: Ramiro, Mario.
1. Arte 2. Fotografia 3. Teoria de Arte 4. Natureza
I. Título. II. Ramiro, Mario.

André Feliciano

Dissertação apresentada ao Programa de Pós-Graduação em Artes Visuais da Escola de Comunicações e Artes da Universidade de São Paulo, como exigência parcial para obtenção do Título de Mestre em Artes. Área de Concentração Poéticas Visuais, sob orientação do Prof. Dr. Mario Ramiro. 
BANCA EXAMINADORA

São Paulo, 
Agradeço

Malraux, Dubois, Flusser, Ramiro, Allessandrini, Feliciano, Mencio, Chaimovich, Sanmartin, Brandão, Monachesi, e amigos. 
Neste texto apresento um modo de perceber o ambiente da arte sob o ponto de vista da filosofia da fotografia. Inicialmente, elaboro a noção de uma natureza fotográfica da arte utilizando como base os pensamentos de Malraux, Dubois e Flusser. Em seguida, ao relacionar os três autores, desenvolvo a ideia de uma sistema de funcionamento para a arte baseado na própria fotografia. Para finalizar, utilizo meu trabalho visual como ponto de partida para cultivar a filosofia da fotografia e essa natureza da arte específica.

Palavras-chave: Arte, Fotografia, Teoria da Arte, Natureza.

\section{ABSTRACT}

In this text I present a way of perceiving the art environment from the point of view of the philosophy of photography. Initially, I elaborate a notion of an photographic art nature based on the thoughts of Malraux, Dubois and Flusser. Then, I relate these three authors to develop the idea of an art system based on photography itself. Finally, I use my visual work as a starting point to cultivate the philosophy of photography and the nature of this particular art.

Key words: Art, Photography, Art Theory, Nature. 


\section{Parte 1: Pesquisa Teórica}

Introdução

A Relação da Arte com a Natureza não é a Natureza-da-Arte

A Natureza Fotográfica da Arte: Passado

A Natureza Fotográfica da Arte: Presente

A Natureza Fotográfica da Arte: Futuro

O Sistema Fotográfico da Arte.

Conclusão

\section{Parte 2: Reflexão sobre a Produção Artística}

Introdução

A Fotografia sem o Aparelho Fotográfico

A Fotografia sem a Imagem Técnica

A Fotografia sem o Ato de Fotografar

A Filosofia da Fotografia

A Fotografia como Cultura

A Fotografia como Escrita

Conclusão 
Parte 1: Pesquisa Teórica 
Em nosso entorno podemos reconhecer vários tipos de natureza, cada uma com suas devidas particularidades: a natureza da matemática, a natureza da filosofia, a natureza dos seres vivos, etc. Decidi cultivar a natureza da arte.

Para me comprometer com esta tarefa um tanto complicada deixei de ser artista e inventei uma nova profissão: jardineiro de arte, cujo objetivo é, e não poderia ser outro, cultivar a natureza da arte. Como não há nenhum manual de conduta para esse trabalho, desde 2006, quando oficialmente me tornei jardineiro ${ }^{5}$, busco definir, na tentativa e na intuição, formas de agir. Refleti: no ambiente de arte existem várias profissões, tal como historiador, crítico, artista e jardineiro. Cada uma delas possui uma relação particular em relação ao tempo da arte. O historiador estuda o passado da arte, o crítico utiliza os conceitos estabelecidos durante a história para analisar o presente da arte, o artista produz a contemporaneidade da arte e o jardineiro cultiva algo que apenas tomará forma no

\footnotetext{
5. Depois de minha aprovação na banca de graduação como Bacharel em Educação Artística (2006) na FAAP meu orientador, Felipe Chaimovich, falou: "André, agora você é oficialmente um jardineiro."
} 
futuro. Nesse sentido, estabeleci que o meu campo de atuação não é a atualidade, pois não trabalho para problematizar a contemporaneidade com o faria um artista, mas cultivo algo que vai ser elaborado junto do passar do tempo.

Então, para dar início a esse trabalho a longo prazo, me pergunto: o que cultivo? Existe uma naturez̧a da arte cultivável? Há como determinar o que ela ê? Para meu trabalho ser bem sucedido, antes de qualquer coisa, é indiscutivelmente necessário determinar e particularizar a natureza com a qual vou trabalhar. Desse modo, neste texto apresento uma noção específica de natureza da arte construída a partir da relação entre três livros: "O Museu Imaginário" de André Malraux ${ }^{6}$ (1965/2000), “O Ato Fotográfico” de Philippe Dubois" (1990/1993), e "A Filosofia da Caixa Preta, Estudos para uma Futura Filosofia da Fotografia" de Vilém Flusser ${ }^{8}$ $(1983 / 1985)$.

Dessa forma, vou elaborar uma noção de natureza da arte específica baseada nas características da fotografia, que nomeei no presente texto de "natureza fotográfica da arte". Malraux servirá de base para teorizar o passado dessa natureza, Dubois o presente e Flusser o futuro. Uma vez determinada a natureza que brota nesse terreno, poderei, então, começar a cultivá-la.

6. MALRAUX, André. O Museu Imaginário. Lisboa: Edições 70, [1965] 2000.

7. DUBOIS, Philippe. O Ato Fotográfico. Campinas: Papirus, [1990] 1993.

8. FLUSSER, Vilém. A Filosofia da Caixa Preta: Estudos para uma Futura Filosofia da Fotografia. São Paulo: Hucitec, [1983] 1985.
A Relação da Arte com a Natureza

NÃo É A NATUREZA-DA-ARTE

De um modo geral, de acordo com a introdução do livro "A Natureza" de Maurice Meleau-Ponty ${ }^{5}$, a palavra natureza em grego deriva de um verbo que faz alusão ao vegetal; já a palavra latina deriva de nascor, nascer, viver. Existe natureza por toda parte onde há vida. É o nosso solo, o que nos sustenta, o primordial não-construído. Geralmente não está ligada ao discurso e ao pensamento elaborado, pois seu sentido se dá a partir de dentro, de seu interior, "naturalmente" e não “acidentalmente". Pode-se pensar que a natureza gera e alimenta sua própria vida de forma independente.

Assim, se existe uma natureza da arte, qualquer que seja sua forma, esta deverá estar presente e ativa em toda sua história, desde o passado até o futuro, como algo primordial de onde as obras de arte se alimentam e retiram seu sentido. Será que é possível encontrar esse algo "em comum" em uma história da arte cheia de mudanças e períodos completamente distintos entre si?

O primeiro passo para se pensar a natureza da arte pode ser o de relembrar a extensa história existente entre a arte e a nature-

5. MERLEAU-PONTY, Maurice. A Naturęa. São Paulo: Martins Fontes, 2006. 
za. Mesmo que o objetivo do presente texto não seja estudar os modos de representação da natureza pela arte, ou as diferentes noções de natureza encontradas nas obras ao longo da história pois, diferentemente, procuramos por uma "essência da arte" -, podemos começar por aí.

No decorrer da história, a relação da arte com a natureza ocorreu de modo um tanto complexo, pois encontramos diferentes noções de "natureza" em diferentes períodos da arte. $\mathrm{Na}$ Grécia antiga a natureza era habitada pelos Deuses, já na Florença Renascentista era mais racional, e no Romantismo mais selvagem e apaixonada. Em cada época da história se formou uma concepção de natureza diferente de acordo com a visão cultural em vigor. Diante disso, a princípio, não existe uma única concepção de natureza que perdurou igual durante toda história da arte, mas, pelo contrário, existiram noções de natureza que variaram junto com as transformações da própria arte. Michel Ribon $(1991)^{6}$ comenta isso muito bem:

A natureza tal como a percebem o homem e qualquer artista não está submetida a modelos culturais que, em ampla medida, a criação artística deixou atrás de si? Assim, na Grécia antiga, a natureza é concebida tanto como habitada pelos deuses, para lhe oferecer uma segunda morada, quanto como conjunto das realidades sensíveis que participam do mundo inteligível; na época clássica, a natureza é polida, a racional e a bela harmoniosa; mais tarde é a grande mãe provedora, a selvagem, a apaixonada e a veemente, com

6. RIBON, Michel. A Arte e A Natureza. Campinas: Papirus, 1991. suas sublimes tempestades românticas; enfim, ela se torna o conjunto das singularidades, bizarrices e convulsões que celebram os simbolistas e surrealistas. Nós apreendemos a natureza apenas através da ideias que dela formamos, que a história humana, por meio tanto da arte quanto da filosofia e da ciência, não cessa de elaborar e questionar. (p. 18)

Nessa mesma linha de pensamento, Ribon particulariza cada momento da história da relação da arte com a natureza. Poderíamos discutir sobre o belo artístico e o belo natural nas visões de Kant e Hegel, como também sobre a natureza romântica de Schelling e Friedrich. Poderíamos refletir sobre os vários estilos de mimese presente nos seus mais diversos modos de representação, assim como poderíamos pensar sobre a jardinagem e o paisagismo.

Surge a pergunta: será que a natureza da arte ou a "essência" da arte pode ser considerada como simplesmente a história das relações entre a arte e a natureza descrita por Ribon? Será que a natureza da arte pode ser apenas a história dos modos de representação e idealização do "objeto natureza" no campo da arte? Ou será ela algo mais primordial, algo presente na noção de arte da história inteira? Algo capaz de alimentar com sentido os princípios fundamentais da arte como um todo? A grande pergunta é: será que esse "algo" pode ser a fotografia?

A fotografia, quando foi inventada, inaugurou um novo modo de representação da natureza, mas principalmente modificou a noção da arte independentemente se a natureza é ou não representada. No decorrer deste texto vamos averiguar como a fotografia mo- 
dificou o modo de pensar a arte como um todo, incluindo seu passado, presente e futuro.
A Natureza Fotográfica da Arte: Passado

De acordo com André Malraux ${ }^{5}$, com a invenção da fotografia em meados do século XIX, o modo como percebemos a história da arte e o modo como entendemos as relação entre arte e natureza foram retroativamente modificadas, de maneira que, a partir de então, podemos considerar que um novo passado foi anacronicamente inventado. Surge uma pergunta importante: como a fotografia que apenas foi inventada em meados do século XIX pode ter influenciado a noção de arte de uma obra Renascentista do século XV? Ou, como uma escultura grega pode ter sofrido influência da fotografia inventada dois mil anos depois?

Como isso é possível? Como a fotografia que "apenas registra cenas do mundo" pode ter transformado de modo tão profundo a noção de arte da história toda, a ponto de modificá-la? Como que, a partir de então, os fundamentos da arte do passado incorporaram anacronicamente qualidades fotográficas? Como a fotografia se infiltrou desse modo tão intenso na arte? 
Quando a fotografia foi inventada, além de ser um novo meio de representação do mundo, proporcionou à arte um poderoso mecanismo de memória. Antes da fotografia, um entusiasta da arte precisava visitar pessoalmente um museu, percorrer todas as suas salas e se lembrar como podia das obras ali presentes. Ele precisava, caso quisesse conhecer mais as obras de artistas italianos, por exemplo, viajar até a Itália e tentar conhecer uma parcela delas. Caso não visitasse um certo museu em um certo país, nunca iria conhecer as obras ali presentes. Mesmo se esse entusiasta tivesse condições de viajar para muitos lugares, apenas iria conhecer algumas obras disponíveis nos museus abertos ao público. Devemos considerar também que o Louvre, por exemplo, definia um critério e organizava sua coleção de acordo com uma hierarquia baseada em uma tradição específica, deixando muitas obras de fora dessa seleção. Ou seja, esse entusiasta da arte vai apenas conhecer uma pequena parte das obras de arte, expostas hierarquicamente nos museus que pode visitar.

Hoje em dia, possuímos em nossas mãos livros com reproduções fotográficas de obras de arte e, num folhear, temos acesso à história inteira. Dispomos de, sem sair de casa, por vários meios diferentes, acesso a todas obras de arte já realizadas. Podemos ver desde obras expostas nos museus, até as obras excluídas deles. Criamos, nesse conjunto de obras fotografadas, de acordo com Malraux (1965/2000), um museu imaginário que modifica para sempre o modo como nos relacionamos com a arte:
Hoje, um estudante dispõe da reprodução a cores da maior parte das obras magistrais, descobre muitas pinturas secundárias, as artes arcaicas, a escultura indiana, chinesa, japonesa e pré-colombiana das épocas mais antigas, uma parte da arte bizantina, os frescos românticos, as artes selvagens e populares. Em 1850 quantas estatuas se encontravam reproduzidas? [...] conhecia-se o Louvre (e algumas das suas dependências) que cada um recordava como podia; hoje, dispomos de mais obras significativas, capazes de colmatar as falhas da memória, do que as que um grande museu é capaz de conter. Na verdade, criou-se um Museu Imaginário, que vai aprofundar ao máximo o incompleto confronto imposto pelos verdadeiros museus: respondendo ao apelo por estes lançado, as artes plásticas inventaram a sua imprensa. (p. 14)

O autor refere que a fotografia, nesse sentido, não apenas modificou o mundo do presente ao ser um novo meio de representação, mas também mudou nossa relação com o mundo do passado. Como dito anteriormente, até o século XIX nem todos conheciam por inteiro o conjunto de obras de arte produzidas até o então; Baudelaire, por exemplo, o precursor da crítica de arte, nunca viajou à Itália e, portanto, nunca viu as obras dos museus italianos. Ele não conheceu as principais obras de Greco, Michelangelo, Masaccio, Piero della Francesca, Ticiano etc. De modo geral, as pessoas apenas conheciam algumas obras de arte, nunca todas.

Havia, por outro lado, as gravuras que mais "traduziam" e "interpretavam" as obras do que as "reproduziam", e serviam como referências para aqueles que não podiam ver a obra ao vivo. Entretanto, essas pequenas gravuras em preto e branco não mostra- 
vam nem a cor e nem a dimensão da obra, e ganhavam, por sua vez, deformações de acordo com o estilo do gravador. Hoje, em comparação, um estudante possui em mãos cópias fotográficas coloridas em boa resolução das maiorias das obras de arte de toda história. De que maneira o acesso a todas essas fotografias de reprodução nos afetou?

A primeira grande mudança em nossa percepção do passado com a invenção da fotografia foi a respeito do caráter ilusionista da arte. Até o século XIX a arte sempre esteve ligada à representação da natureza e à utilização mimética de suas formas. Por muito tempo, a pintura manteve seu poder devido à sua capacidade de criação do irreal ou do ilusório. A arte era elaborada para o prazer da imaginação e, cada pintor com seu estilo próprio, elaborava uma ficção de que o público tanto gostava. Com a invenção da fotografia, entretanto, devido sua à capacidade de criar "mecanicamente" uma ilusão de mimese da natureza, pelos olhos da nova modernidade, o caráter ilusório da arte não ofereceu mais desafios e perdeu sua importância. Desse modo, toda arte do passado baseada na capacidade de criar ilusões deixou de ter astúcia e, mesmo pinturas com estilos totalmente diferentes e até mesmo rivais, foram "pasteurizados" e passaram a pertencer a um mesmo grupo. Tanto uma pintura clássica quanto uma pintura barroca, por exemplo, deixaram de ter diferenças nesse plano e tornaram-se apenas uma arte caracterizada pela representação e pela ilusão.

Com a perda de importância do caráter ilusório da arte, na passagem do passado tradicional para a arte moderna, o pintor deixa de mimetizar a natureza e substitui a arte da ilusão por uma arte autônoma e independente. As cores dos quadros impressionistas, por exemplo, se relacionam entre si e não mais com o mundo exterior, não são mais orientados pela imitação: a arte começa a se transformar em um "universo pictural autônomo, coerente e particular” (MALRAUX, 1965/2000, p. 61). Enfim, a relação da arte com a natureza se modifica para sempre e o artista agora não mais trabalha para elaborar uma ilusão da natureza, mas, de acordo com Malraux (1965/2000), trabalha em função da própria arte.

Ao mesmo tempo, a fotografia possibilita uma ótima reprodução das obras em livros. Os álbuns fotográficos de arte davam a conhecer uma profusão de obras de todas as épocas, de todos os estilos e de todos os lugares, em uma grande afloramento simultâneo de todas as obras da humanidade. Muitas obras que antes eram ignoradas pela história oficial e não eram expostas nos museus foram "ressuscitadas" e agora podiam existir lado a lado com as obras primas dos museus importantes. Desse modo, ocorreu uma reorganização de toda hierarquia da arte e uma mudança profunda no modo como avaliamos as obras.

Como exemplo desse novo modo de pensar a história da arte, apresento o famoso "Atlas Mnemosine" criado por Aby Walburg no começo do século XX. Seu objetivo era construir uma nova lógica da história a partir de reproduções de obras de arte. Essa nova lógica, no entanto, não obedecia mais a uma linearidade de acontecimentos ou a uma hierarquia de estilos, mas podia gerar relações inusitadas entre as obras de diferentes períodos devido às 
suas semelhanças visuais.

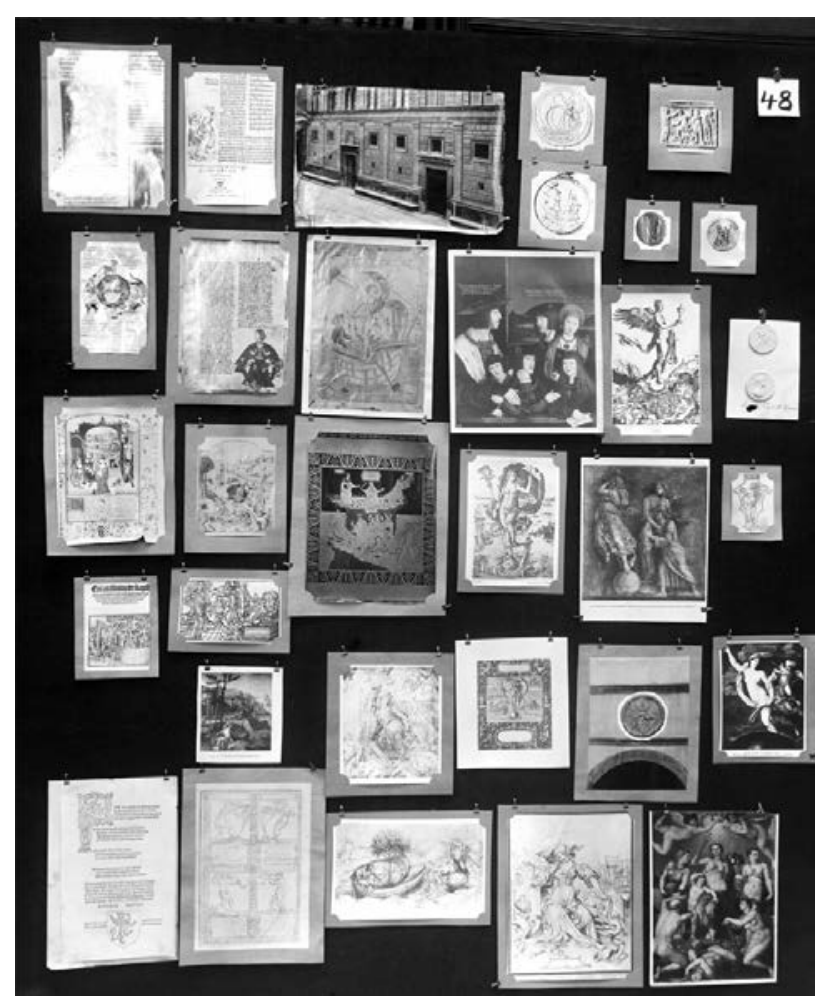

Figura 1: Fragmento do Atlas Mnemosine de Aby Warburg (1866 - 1929)

Nesse mesmo contexto, com a chegada dos álbuns de fotografia, a noção de obra prima mudou completamente. Entre os séculos XVI e XIX, de acordo com Malraux (1965/ 1990) a obra prima era um quadro que a imaginação não podia aperfeiçoar, era a obra melhor executada de um pintor de acordo com os parâmetros da época. No momento em que conseguimos conhecer de uma só vez, em um único álbum, todas as obras de um mesmo autor ou de uma mesma época, a obra prima deixa de ser avaliada isoladamente e passa a pertencer a um todo, sendo agora a obra mais significativa do inventor de um estilo, ou a obra mais representativa de uma escola inteira. As obras de arte passam a ser julgadas em blocos. O barroco, por exemplo, deixa de ser comparado com o clássico e deixa de ser voluptuoso, patético e desordenado para ganhar qualidades autônomas. O gótico, da mesma forma, foi ressignificado e passou a estar livre do julgamento renascentista. Desse modo, muitos estilos antigos antes ignorados agora tiveram uma segunda chance de apresentar suas qualidades de modo independente.

Ao mesmo tempo em que os álbuns de fotografia possibilitam essa reorganização na hierarquia e no modo como entendemos a história, também provocam um poderoso meio para a intelectualização da arte. Vamos entender por que.

Em primeiro lugar, as obras nesses álbuns de reprodução estão sujeitas à técnica da fotografia. Elas se transformam devido ao ângulo, à luz, ao enquadramento, à cor da fotografia e, de modo geral, adquirem qualidades visuais que antes não existiam. Nesse sentido, uma escultura pode ganhar dramaticidade se fotografada de certo ângulo, ou um detalhe de uma pintura pode ser fotografado isoladamente e ganhar destaque, ou um buda de 20 metros pode estar na mesma página e lado a lado de um pequeno amuleto, entre inúmeras possibilidades. De modo geral, as obras são transformadas em imagem fotográficas, redimensionadas para caberem dentro de um mesmo livro e, assim, homogeneizadas para 
estarem lado a lado, com um mesmo aspecto visual em livros de reproduções.

Assim, nesses livros, as obras fotografadas estão sujeitas às novas interpretações. Além de estarem planificadas em suas páginas e ingressarem no museu imaginário, podem ganhar um novo sentido. Uma pintura magistral que antes se encontrava em uma coleção particular na França e um afresco secundário de uma igreja espanhola agora podem estar na mesma página de um livro. O grande mosaico bizantino da igreja de São Marco em Veneza, Itália, pode estar lado a lado com um sarcófago egípcio feito centenas de anos antes. As obras de arte, nesse museu não-hierárquico, não mais possuem uma distância física e temporal entre si, e podem se aglomerar livremente.

Porém, quando as obras se deslocam de seu contexto inicial ao serem reproduzidas em livros, perdem sua função de origem. As pinturas da Capela Cistina, por exemplo, deixam para trás sua função religiosa e passam a ser apenas arte. As pinturas perdem suas molduras, as esculturas se desconectam de seu contexto, e as obras em geral perdem o motivo original pelo qual foram feitas. Ou seja, nesse deslocamento para o livro de reproduções, as obras deixam de ser objetos com uma função própria e passam a ser arte em um lugar fictício. Elas perdem sua presença para serem ideias, criações e conceitos em "um lugar imaginário que só existe por si”. (MALRAUX, 1965/2000, p. 225). Os álbuns de reprodução, assim, criam um mundo de arte intelectualizado e com um tipo próprio de emoção: a história da arte passa a ser um lugar de criações intelectuais.
Dessa forma, a fotografia influencia o modo como compreendemos toda a história, modifica a noção de arte anacronicamente e prepara o terreno para a elaboração de uma arte moderna desconectada da natureza e de uma arte contemporânea intelectualizada. De certo modo, a fotografia expandiu seu domínio tanto para o passado, anterior à sua invenção, quanto para o futuro, e abre caminho para substituir as ideias de Ribon sobre a transitoriedade da relação da arte com a natureza por um pensamento mais radical: a unicidade da fotografia como constituinte de uma natureza da arte geral.

Malraux (1965/2000), além de demonstrar com muito mérito a influência da fotografia na nossa noção de arte do passado, aponta a influência da fotografia na arte produzida desde de sua invenção. Quais foram as consequências do musen imaginário na nova arte moderna?

\begin{abstract}
Nenhuma foto da Vitória da Samotrácia nos emociona tanto quanto esta estátua (de resto isolada) que se ergue, como numa proa, ao cimo da escadaria do Louvre; mas quantas esculturas nos atingem menos do que as suas fotos, quantas nos foram reveladas por estas? A tal ponto que o museu começa a assemelhar-se ao museu imaginário: as estátuas cada vez menos agrupadas, cada vez mais bem iluminadas, e a Pietà Rondanini de Miguel Ângelo, no castelo Sforza (também ela isolada) parece - admiravelmente - esperar pelos fotógrafos. (MALRAUX, 1965/2000, p. 106)
\end{abstract}

O mundo físico começa a se assemelhar com o mundo imaginário criado pela fotografia. Os museus começam a isolar suas obras da mesma forma que uma estátua romana é isolada num álbum de fotografias, ou que um afresco é separado de todo seu entorno 
da igreja onde se encontra. Aos poucos, o lugar de exposição de obras de arte se transforma num "ambiente fotográfico" e as salas ganham uma boa iluminação, as paredes são pintadas de branco e cada vez mais há mais espaço vazio entre uma obra e outra em uma exposição. De certo modo, há uma necessidade de transportar o ambiente intelectualizado da história da arte fotografada para o espaço físico.

Essa diferença fica muito marcada ao visitar coleções reais antigas que não sofreram mudanças em suas salas de exposição, onde um quadro de Diego Velásquez está pendurado na parede forrada com um tecido estampado, do lado do relógio voluptuoso e sobre a cômoda de mármore, num lugar originalmente iluminado por velas - um ambiente totalmente confuso aos olhos de um espectador acostumado com as salas brancas de um museu. Enfim, podemos pensar que o cubo branco ${ }^{6}$ utilizado como modelo de sala expositiva na arte moderna e contemporâneas é a materialização de um espaço fotográfico criado pelo museu imaginário.

6. Referência ao livro: O'Doherty, Brian. Inside the White Cube: The Ideology of the Gallery Space. San Francisco: California University Press, 1999.

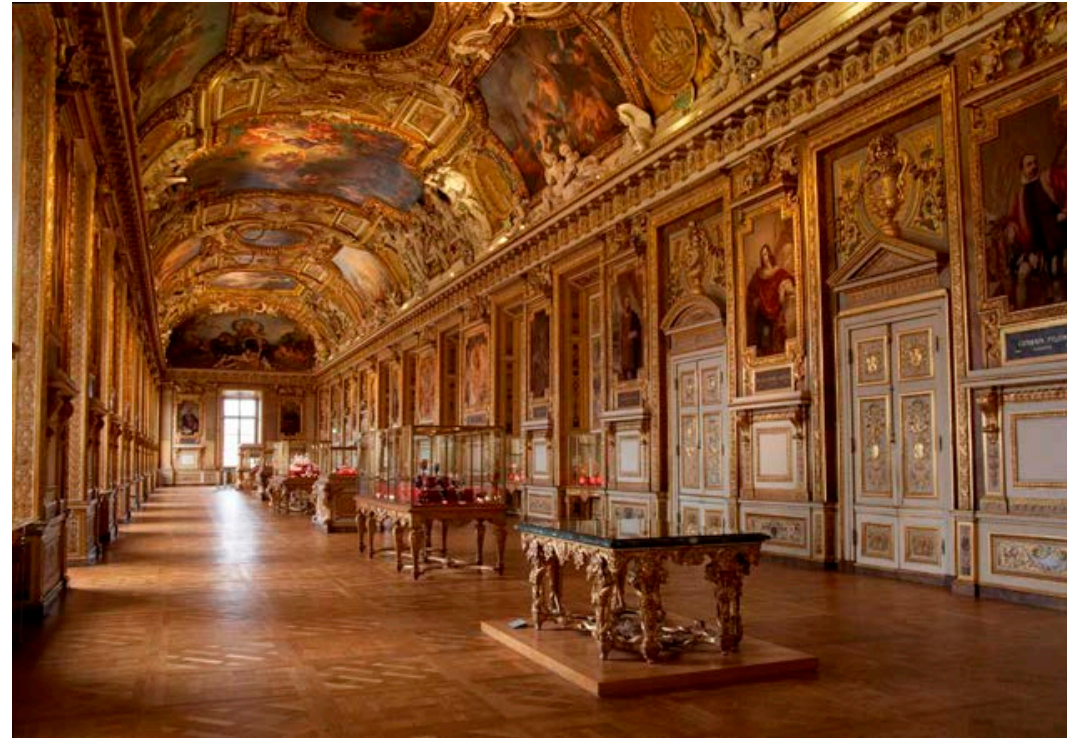

Figura 2: Interior da Galeria de arte Apollo (1781) do Louvre em Paris.

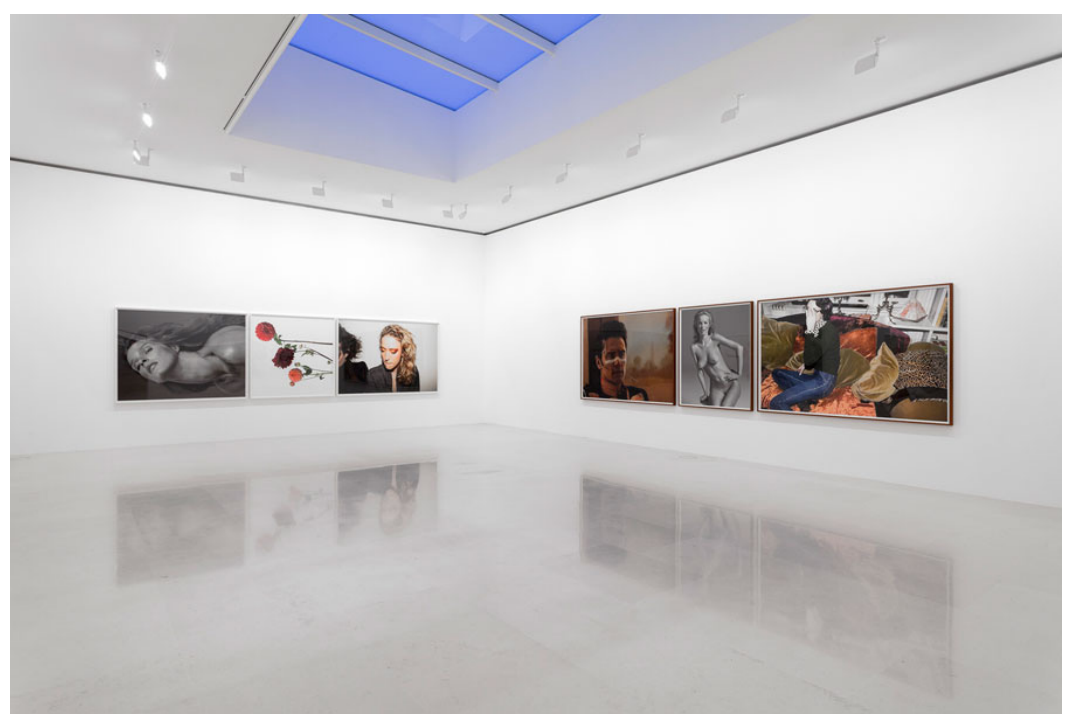

Figura 3: Interior da galeria de arte Gagossian (2013) em Paris; exposição de "INEZ \& VINOODH". 
Entretanto, não apenas o local de exposição incorporou características "fotográficas", mas também as obras de arte que vêm sendo criadas desde então. Não há citação mais exemplar do que a célebre frase de Walter Benjamin: “Tudo muda, se da fotografia como arte passa-se à arte como fotografia."'(citado por DUBOIS, $1990 / 1993$, p. 251) ${ }^{7}$ Como podemos confirmar isso? Como podemos averiguar se a fotografia está realmente presente na constituição da natureza da arte? Será que uma pintura abstrata é fotográfica? Será que um ready-made é fotográfico? Será que uma performance também é uma manifestação de "natureza fotográfica"? Se a história da arte se "transformou" contra sua própria vontade e incorporou qualidades fotográficas, será que a arte moderna e contemporânea conseguiram se desvincular dessa armadilha?

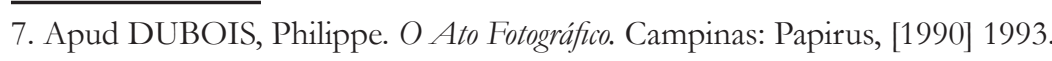
p. 251.
A Natureza Fotográfica da Arte: Presente

Philipe Dubois $(1990 / 1993)^{5}$ desenvolve uma análise semiótica da fotografia que pode ser muito útil para responder a essas questões e analisar a influência da fotografia no presente. Diferente de outros autores que estudam o significado interior da imagem fotográfica, seu livro discorre sobre o ato produtivo que define a fotografia e sua relação com seu exterior. Dessa forma, o autor ajuda a definir uma lógica específica da fotografia baseada em suas relações com o mundo. A partir de então, poderemos averiguar se essa lógica fotográfica também está presente na produção das obras de arte.

Para o autor, a fotografia, como qualquer meio de expressão, deve ser estudada de acordo com a "relação específica existente entre o referente externo e a mensagem produzida por esse meio" (DUBOIS, 1990/1993, p. 25). Nesse sentido, quando o mundo exterior é fotografado e é gerada uma imagem fotográfica, pode-se extrair dessa relação um dado importante sobre sua natureza. Dubois (1990/1993) nos apresenta uma análise histórica dessa relação que pode nos orientar para encontrar uma natureza para fotografia e, como mostrarei mais adiante, uma natureza para a arte.

5. DUBOIS, Philippe. O Ato Fotográfico. Campinas: Papirus, [1990] 1993. 
O discurso mais primário diz que a fotografia é como um espelho do real. Desde sua invenção no século XIX esse discurso já estava em vigor e, sendo contra ou a favor, não se discordava da capacidade de a fotografia imitar perfeitamente a realidade. Tão perfeita é a imagem, que se torna quase natural, fruto de um meio mecânico, sem a intervenção da mão e do gesto humano, portanto, como uma "não-arte". Deriva desse mesmo discurso a ideia de que a fotografia "libertou" os artistas da necessidade de representar o mundo para poderem caminhar em direção à abstração, uma vez que a fotografia já exercia a função de mimetizar.

Na continuidade, Dubois (1990/1993) explica que se elaborou um discurso em contrapartida ao discurso da mimese, considerando a fotografia como transformação do real. Ao invés de copiar a realidade, a fotografia a desconstrói e apenas é entendida através dos códigos vigentes, a partir da interpretação de quem a olha. Nesse momento, tornam se conscientes as modificações que a fotografia provoca em relação ao real, desde o enquadramento e o ângulo de visão até o tipo de impressão e cor da imagem. Nesse pensamento, a fotografia não passa de uma ficção, de um mecanismo controlado para criação de um efeito de perspectiva comum.

Em um terceiro momento, quase como uma dialética entre os dois momentos anteriores, a fotografia começa a ser pensada como um traço do real.

Algo de singular, que a diferencia dos outros meios de representação, subsiste apesar de tudo na imagem fotográfica: um sentimento de realidade incontornável do qual não conseguimos nos livrar apesar da consciência dos códigos que estão em jogo nela e que se combinam para sua elaboração. (DUBOIS, 1990/1993, p. 26).

Baseando-se nos estudos de Charles Sanders Peirce, para Dubois (1990/1993), nesse momento a fotografia poderia ser considerada um indice, ou seja, uma representação que carrega alguma conexão física com o real, mas não necessariamente realiza essa conexão pela aparência ou pelo significado, podendo ser uma conexão apenas pragmática.

Dubois irá se basear nesse terceiro momento para definir uma lógica específica para a fotografia. Ou seja, a fotografia é um índice do mundo e, além disso, um modo particular para se pensar esse mundo, uma verdadeira categoria epistêmica. Podemos, assim, nos relacionar "fotograficamente" com as situações e com os objetos à nossa volta mesmo se não estamos utilizando uma câmera fotográfica ou gerando imagens fotográficas. Podemos pensar fotograficamente sobre a natureza, sobre a nossa vida e sobre todas situações a que estamos submetidos. Em suas palavras:

[é necessário] colocar bem em evidência o fato de que a fotografia define uma verdadeira categoria epistêmica, irredutível e singular, uma nova forma não somente de representação, mas mais fundamentalmente ainda de pensamento, que nos introduz numa nova relação com os signos, o tempo, o espaço, o real, o sujeito, o ser e o fazer. (DUBOIS, 1990/1993, p. 94).

Essa afirmação é muito importante, pois nos oferece uma ferramenta teórica para analisar se essa lógica fotográfica está pre- 
sente no fazer artístico moderno e contemporâneo, mesmo em trabalhos que não utilizam a técnica fotográfica como meio. Além disso, em conjunto com as ideias de Malraux (1965/2000) sobre a "incorporação" das qualidade fotográficas pelo passado, podemos, então, supor que o modo de pensar fotográfico, atualmente e anacronicamente, constitui o terreno da natureza da arte como um todo, de onde brotam as obras de arte com suas devidas particularidades.

Dubois (1990/1993) deixa muito claro a estreita relação entre fotografia e arte, entre a epistemologia da fotografia e o fazer artístico. No entanto, para conseguirmos entender esse pensamento, deveremos primeiro conseguir nos desvincular da ideia de uma fotografia que 'copia a realidade' ainda muito instintiva, por uma fotografia que apenas 'teve uma conexão física com uma realidade que não é mais a mesma'. Ou seja, devemos nos esforçar para entender a fotografia como traço do real, o que lhe confere a condição de índice pragmático.

Dessa forma, podemos averiguar se a arte utiliza um modo de pensar fotográfico para se elaborar, e se se relaciona com o mundo da mesma forma que uma fotografia o faz. Ou seja, se a hipótese apresentada neste texto procede, a arte deve ser um índice do mundo assim como uma fotografia é. Ambas devem ser produto de uma mesma lógica, o que Dubois chama de "lógica do índice".

Lembraremos em primeiro lugar, de maneira muito geral, que todas essas práticas artísticas [de arte contemporânea], sem distinção, funcionam em seu princípio, no que as fundamenta, de acordo com uma lógica que também é exatamente a da fotografia: a lógica do indice. (DUBOIS, 1990/1993, p. 280).

O que seria a "lógica do índice"? Ou melhor, como podemos interpretar e compreender a frase acima? Talvez, da seguinte maneira: o índice é uma representação que carrega uma conexão física com o real, mas não necessariamente realiza essa conexão pela aparência ou pelo significado, podendo ser uma conexão apenas pragmática. Ou seja, se a arte contemporânea funciona de acordo com a lógica do índice, ela, portanto, mesmo sem ter alguma semelhança com o real ou mesmo gerando um significado totalmente diferente para esse real, depende de uma conexão física com ele para ter significado (o que Dubois chama de contiguidade referencial). Sem essa ligação pragmática com o real, a arte contemporânea perderia todo seu sentido.

A arte moderna, por sua vez, não coloca em prática a lógica do índice como faz a arte contemporânea. Por isso, não necessita de uma conexão pragmática com o mundo para ter sentido. Mas, diferentemente, a utiliza, como veremos mais adiante, no plano das ideias, para criar uma noção de arte específica baseada na fotografia.

No mundo, entretanto, de acordo com Dubois (1990/1993) existem vários tipos de índices. O que justifica a fotografia ser considerada um modo particular de pensamento (categoria epistêmica) é justamente sua particularidade como "índice fotográfico". Ou 
seja, o que faz da fotografia única, diferente de todos os outros meios, reside em seu modo exclusivo de se relacionar com o mundo. De acordo com Dubois (1990/1993), o índice fotográfico possui três características que o torna singular: ser ao mesmo tempo uma impressão separada, plana e luminosa/descontínua.

Assim, se queremos entender por que a arte funciona de acordo com a lógica do índice, devemos, antes, entender como o próprio índice fotográfico funciona.

De acordo com Dubois (1990/1993), o índice fotográfico é separado pois, apesar de manter uma conexão com seu referente, também possui uma distância física dele, espacial e temporal. Ou seja, a foto é gerada a partir de uma ligação com seu referente, porém, após seu ato, não mais se conecta no tempo e no espaço: aquele momento já passou e aquele objeto já não é mais o mesmo. Por exemplo, quando fotografamos uma pessoa pulando dentro de um lago, mesmo que a foto mostre essa pessoa parada no ar, ela, na realidade, já vai ter caído na água.

O índice fotográfico também é plano, achatado. No momento anterior ao ato fotográfico, a câmera pode ser ajustada para melhor adequar a transposição do mundo tridimensional à superfície emulsionada (ou ao sensor digital) plana da fotografia, controlando-se a abertura do diafragma, a focalização, entre outras regulagens. Entretanto, esse fotógrafo, diferente do pintor, por exemplo, gera a imagem em um ato global e único, no qual tudo é dado de uma só vez. O fotógrafo pode manipular a foto antes ou depois, mas seu ato constitutivo é plano, achatado e por inteiro.

O índice fotográfico também é luminoso/descontínuo ${ }^{6}$. No momento que o fotógrafo aperta o botão da câmera, a luz entra no aparelho como se fosse um lençol sendo suavemente colocado sobre a cama. Entretanto, no momento que esse plano homogêneo de luz encosta no material fotossensível do filme (atualmente um receptor digital), na tradução da luz em imagem, ocorre um distúrbio e todo plano de luz se transforma em pontos aleatórios e fractais que formarão uma imagem descontínua. O filme da fotografia é formado por grãos (e os sensores digitais por pixels) que constituem o corpo da imagem e, por serem pontos individuais, "não tem neles mesmo qualquer relação formal com a 'imagem', com a representação analógica dos objetos, com as figuras, a cena, o espetáculo que finalmente será reconhecido por aquele que olha a foto." (DUBOIS, 1990/1993, p. 100).

A seguir, vamos averiguar se essas três características estão presentes e constituem os fundamentos principais da arte moderna e contemporânea. No entanto, devemos procurar essas características na arte lembrando que não estamos analisando as obras em si, mas estamos em busca de seus fundamentos. Nesse sentido, não precisamos analisar as obras individualmente, mas podemos, ao invés, agrupá-las de acordo com suas semelhanças e pensá-las em blocos, como se todas estivessem dentro do museu imaginário pro-

6. No presente texto chamarei apenas de 'descontínuo'. 
posto por Malraux. Se conseguirmos identificar nos fundamentos da arte a lógica do índice fotográfico, teremos, então, mais um forte indício de suas equivalências.

A primeira forma clara de uso da lógica do índice fotográfico na arte ocorreu no impressionismo, no qual o objetivo era representar a luz como se fosse um traço dos objetos, e não mais o objeto em si, assim como um índice fotográfico que, através da luz, capta um traço dos objetos fotografados e não o objeto em si. A arte moderna como um todo, incluindo o impressionismo, o cubismo e as pinturas monocromáticas, para citar apenas alguns, se alimentou de um modo de pensar fotográfico e, com ele, elaborou nova noção de arte. Rosalind Krauss $(2002)^{7}$ diz:

O que a fotografia havia revelado a Degas e Monet era a distância existente entre percepção e realidade. Considerando-se excluídos do agenciamento intrínseco da natureza, percebida como alheia, distante e absorvida na sua própria contemplação, ambos transformaram a unidade decorrente de sua introspeção em solução substitutiva. (p. 74)

De fato, não podemos perceber a lógica do indice em uma análise do fazer de uma pintura moderna. Artistas como Degas ou Monet não estavam interessados em usá-la no ato produtivo de suas obras. Mas, no entanto, utilizaram o modo de pensar fotográfico para elaborar, no plano das ideias, um modo de pensar a arte como algo separado da natureza. Ao mesmo tempo em que a

7. KRAUSS, Rosalind. O Fotográfico. Barcelona: Editorial Gustavo Gili, 2002. fotografia é um índice direto da natureza, ela pode ser impressa e levada para outro lugar - posso ver a foto de uma floresta dentro da minha casa. A fotografia também tem a capacidade de "separar" a natureza fotografada de sua origem real. A arte moderna se fundamentou nisso.

De modo geral, no ponto de vista da semiótica, podemos pensar que as obras de arte modernas podem ser consideradas como um índice plano, separado e descontínuo em relação à natureza, assim como o índice fotográfico. Que obra de arte moderna não buscou ser plana, trocou a ilusão da perspectiva por um espaço de duas dimensões? Que obra de arte moderna não buscou uma desconexão física com a natureza e, assim, sua autonomia enquanto arte? Que obra de arte moderna não dependia do espectador para gerar o seu sentido uma vez que não pré-determinavam o modo com as pessoas iriam interpretá-la? O desenvolvimento da arte moderna marcou o início de uma nova relação com a natureza: o artista deixou de representá-la e passou a "pensá-la fotograficamente": passou a imaginá-la como índice plano, separado e descontínuo.

A utilização, a esse respeito, da noção perciana [de índice] inscreve-se de fato num projeto global, do qual uma das linhas de fundo repousa na ideia de uma passagem da categoria de ícone à de índice, passagem considerada não apenas um marco histórico da modernidade, mas também, mais geralmente, como um deslocamento teórico, onde uma estética (clássica) da mimese, da analogia e da semelhança (a ordem da metáfora) cederia espaço a uma estética do traço, do contato, da contiguidade referencial (a ordem dametonímia). (DUBOIS, 1990/1993, p. 113) 


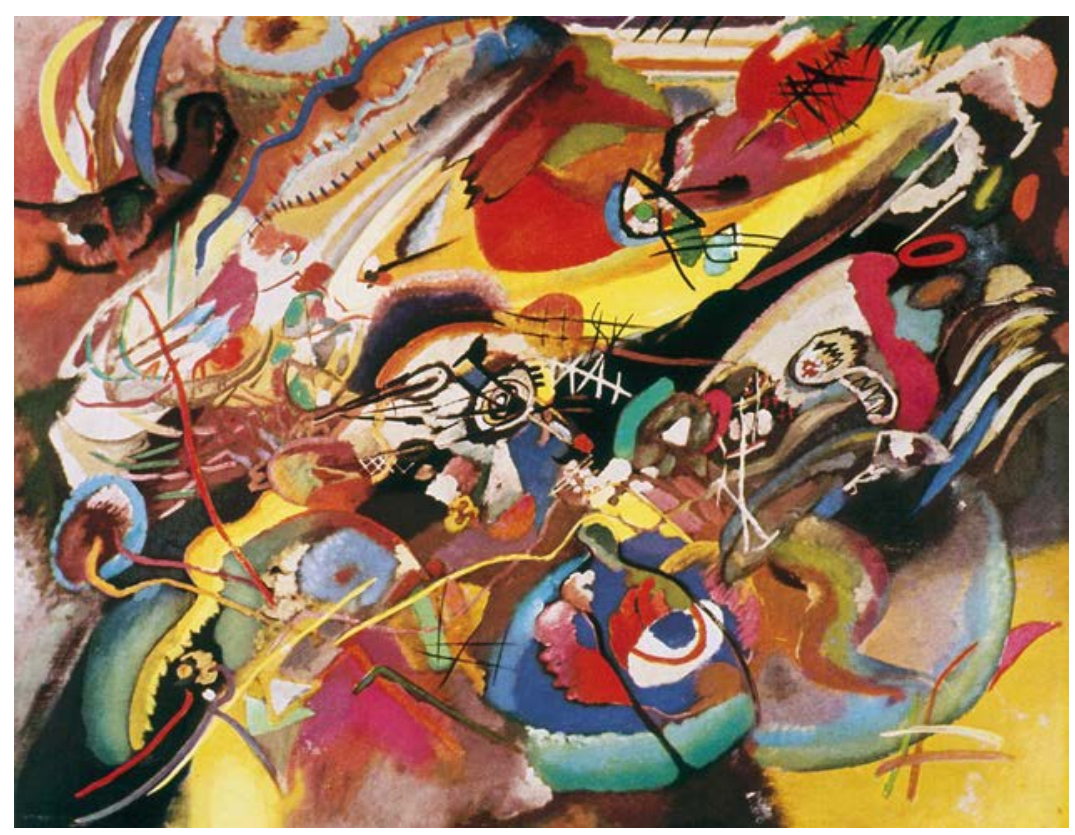

Figura 4: Obra "Skecth for Composition VII" (1913) de Wassily Kandinsky

Se analisarmos a arte moderna como um bloco podemos perceber que o uso desse pensar fotográfico resultou no desenvolvimento de uma noção de arte abstrata (ou não-figurativa) no campo da arte. Uma obra plana, autônoma e aberta é essencialmente uma obra abstrata. De certo modo, as primeiras obras de arte modernas, como por exemplo, as pinturas impressionistas, eram só um pouco abstratas e as últimas, como por exemplo, as pinturas monocromáticas eram totalmente abstratas. Mas, por que podemos considerar que essa noção de arte teve origem na fotografia e não em outro lugar?
A relação da arte com a fotografia é muito complexa. Em primeiro lugar, já está comprovado a influência direta das imagens fotográficas na produção da arte moderna, como a influência da fotografia aérea no suprematismo ${ }^{8}$, o uso de imagens astronômicas por Van Gogh para elaboração de seus céus estrelados, a utilização das cronofotografias de Marey como inspiração do cubismo analítico, do nú descendo a escada de Duchamp, e mais tarde, do futurismo, entre inúmeros outros casos. Porém, o que nos interessa aqui não é a influência da imagem fotográfica na elaboração de obras de arte, mas a influência da epistemologia da fotografia na construção de uma noção de arte moderna. Em outras palavras, nos interessa pensar por que a abstração moderna é, enfim, de um modo de pensar basicamente fotográfico?

A abstração sempre existiu no campo da arte. Qualquer pintura tradicional, como um mural clássico ou um quadro barroco, por exemplo, é uma representação do mundo e não o próprio mundo, criada a partir da capacidade humana de abstrair. Por que, então, a arte moderna irá representar a abstração em si ao invés de utilizá-la para criar uma imagem que representa o mundo? Por que a arte moderna irá, assim, dar autonomia à abstração em relação à representação do mundo e, consequentemente, irá dar autonomia à própria arte?

Não é coincidência que o início da arte moderna foi simultâneo

8. Sobre esse assunto, ver: DUBOIS, Philippe. O Ato Fotográfico. Campinas: Papirus, [1990] 1993. p. 258. 
à invenção da fotografia (em meados do século XIX). O discurso hegemônico diz que a fotografia "libertou" os pintores do dever de representar a natureza, uma vez que ela já realizava isso mecanicamente com perfeição. Picasso, em 1939, diz:

Quando você vê tudo o que é possível exprimir através da fotografia, descobre tudo o que não pode ficar por mais tempo no horizonte da representação pictural. Por que o artista continuaria a tratar de sujeitos que podem ser obtidos com tanta precisão pela objetiva de um aparelho de fotografia? Seria absurdo, não é? A fotografia chega no momento de libertar de qualquer anedota, de qualquer literatura e até do sujeito. Em todo caso, um certo aspecto do sujeito hoje depende do campo da fotografia. (apud DUBOIS, 1990/1993, p. 31)

A fotografia pode ter sim libertado o pintor de seu dever de representar a natureza, mas, ao mesmo tempo, o trouxe para dentro de seu domínio. O que não se percebe, geralmente, é que a mesma lógica fotográfica utilizada para oferecer essa liberdade aos artistas será utilizada na elaboração da noção de arte vigente.

Quando um pintor exclama em voz alta: “eu não preciso mais representar a natureza porque a fotografia me deu essa liberdade". Pensa em voz baixa: "mas agora, o que faço com essa liberdade toda"? A história nos mostrou que os artistas buscaram, como resposta a essa questão, evidenciar os seus próprios mecanismos de funcionamento como parte significativa da obra. Buscavam evidenciar a cor da pintura através da própria cor. Mostravam a matéria da pintura através da própria tinta. Por que essa noção de arte distanciada da natureza, autônoma, abstrata e metalinguística se fundamenta em um modo de pensar exclusivamente fotográfico?

Ao olhar uma fotografia de uma paisagem, por exemplo, somos induzidos a pensar que vemos a própria paisagem. Olhamos a fotografia de uma pessoa e achamos, mesmo que por um breve momento, que vemos a própria pessoa. A fotografia, em sua condição de índice pragmático, nos obriga a pensar o mundo como metalinguagem. Ou seja, o mundo, na fotografia, faz referência a si-mesmo. Dubois (1990/1993) diz:

Existe portanto, entre a fotografia e as várias práticas que serão evocadas aqui, essa primeira relação, essa comparação primária, e ao mesmo tempo fundamental, de princípio, essa epistemé comum chamada 'o indice', isto é, a impossibilidade de pensar o produto artístico sem nele inscrever também (e sobretudo) o processo do qual é resultado. (p. 280)

Nesse sentido, a fotografia oferece à arte um modo metalinguístico de pensar a realidade do mundo. Mas, como também busca por sua autonomia em relação à natureza, acaba por isolar e evidenciar esse pensamento metalinguístico como solução formal. A fotografia não apenas liberou os artistas da necessidade de representação, mas principalmente mostrou um novo caminho a seguir.

Devemos lembrar que a fotografia é a única linguagem criada a partir de uma conexão física com o mundo ${ }^{9}$ e, para ser entendida, torna a metalinguagem uma forma obrigatória de pensamento.

9. Sobre esse assunto, ver: BARTHES, Roland. A Câmera Clara. Rio de Janeiro, Nova Fronteira, 1984 
Nesse sentido, os artistas deixaram de representar a natureza para criar uma arte baseada num modo fotográfico de pensar: a arte se refere à própria arte da mesma forma que uma foto de uma pessoa se refere à própria pessoa. A lógica utilizada é a mesma. Não há outra linguagem que ofereça essa forma metalinguística de pensar e, ao mesmo tempo, propoe uma separação e autonômia em relação à natureza. Não há outra origem para essa conjuntura da arte moderna.

Podemos concluir que a fotografia oferece liberdade aos artistas da necessidade de representação da natureza, mas ao mesmo tempo, os atrai para dentro de seu domínio: os artistas modernos começam a utilizar a fotografia como uma nova natureza para seus trabalhos.

E os artistas contemporâneos? Conseguiram sair do domínio da fotografia? Sobre isso, Rosalind Krauss ${ }^{10}$ diz:

A noção atual de pluralismo estilístico - um dos clichês mais resistentes da crítica americana moribunda - deve ser substituída por um modo de descrição mais eficaz da arte do presente: uma descrição que explique o determinismo histórico que nela atua. Para isso, abri uma nova rubrica: a arte do índice, um termo que seria possível substituir por um outro: o fotográfico. (apud DUBOIS, 1990/1993, p. 109)

Se a arte moderna elaborou, no plano das ideias, uma noção foto-

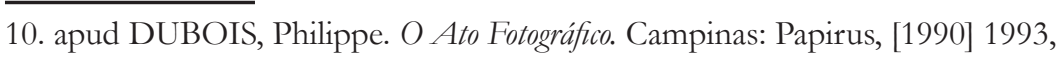
p. 109. gráfica de arte, a arte contemporânea irá colocá-la em prática. Se, na arte moderna, a lógica do índice (e a metalinguagem daí resultante) influenciou diretamente o modo de pensar a arte, na arte contemporânea, influenciará diretamente o modo de agir. Ou seja, ela será incorporada ao próprio fazer artístico e presente na própria constituição do objeto.

Duchamp - que pode servir de modelo e referência para toda arte contemporânea - apesar de em muitos casos não ter praticado a fotografia diretamente, toda sua obra "pode ser considerada como uma reflexão da problemática do traço, de depósito, do contato, da proximidade, da inscrição referencial por intermédio de figuras sempre pragmáticas" (DUBOIS, 1990/1993, p. 113). Ou seja, toda sua obra se apoia em uma problemática fotográfica ${ }^{11}$.

O ready-made, obra chave do pensamento de Duchamp e do fazer artístico contemporâneo, utiliza claramente a lógica do índice fotográfico em sua constituição. Ele pode ser considerado, na prática, como um índice plano, separado e descontínuo.

Em primeiro lugar, o fazer artístico do ready-made é constituído como um ato único, instantâneo e plano. Rosalind Krauss diz: "O ready-made concebido como instantâneo se transforma assim no traço de um acontecimento particular.” (KRAUSS, 2002, p. 84) ${ }^{12}$.

11. Sobre esse assunto ver: KRAUSS, Rosalind. O Fotográfico. Barcelona: Editorial Gustavo Gili, 2002. Capítulo II, subcapítulo "Marcel Duchamp e o Campo Imaginário".

12. KRAUSS, Rosalind. O Fotográfico. Barcelona: Editorial Gustavo Gili, 2002. 
Assim como um fotógrafo, Duchamp, com um único gesto, pode criar um indice do mundo. Ou seja, cria uma representação que carrega uma conexão física com o real, mas não necessariamente realiza essa conexão pela aparência ou pelo significado, podendo ser uma conexão apenas pragmática. O urinol de Duchamp, nesse sentido, apenas carrega uma conexão pragmática com sua origem: ele não tem mais a mesma aparência, não tem mais o mesmo significado, deixou de ser objeto, foi deslocado, sofreu uma mudança de posição, ganhou novo nome, perdeu sua função original e, como índice, é apenas arte.

O ready-made, nesse sentido, se constitui através do ato da separação. Da mesma forma que uma fotografia é um índice fisicamente e espacialmente separado do mundo, o ready-made se constitui e apenas ganha sentido após uma separação temporal e espacial (e conceitual) com sua origem mundana. A mesma lógica presente na prática da fotografia, está presente na prática do ready-made.

Ao mesmo tempo, o ready-made perde seu significado original de objeto sanitário e se torna um objeto com significação aberta. Da mesma forma que um índice fotográfico é descontínuo, o significado do ready-made é indefinido e necessita de uma interpretação exterior para existir. O objeto artístico, nessa situação proposta por Duchamp, passa a ser um objeto intelectual.

Nesse momento o presente texto se torna mais complexo: essa intelectualização dos objetos da arte não é exatamente a consequência do museu imaginário (criado pela fotografia) em nossa visão de arte do passado? Malraux afirma que o "museu imaginário se baseia na metamorfose da presença das obras que contém. (...) Orienta a transformação dos verdadeiros museus por uma intelectualização sem precedentes da arte." (MALRAUX, 1965/2000, p. 216). Não é exatamente isso que Duchamp formaliza em seus ready-mades? Quando ele transforma um objeto comum em um objeto intelectualizado da arte, ao mesmo tempo, também transforma na prática o próprio museu em um espaço intelectualizado. Nesse sentido, podemos falar que Duchamp, em seu fazer artístico, está assimilando o museu imaginário e o transformando em realidade.

A fotografia influencia a arte de várias maneiras e por vários lados, de modo que a visão intelectualizada da arte do passado oferece base para a realização de uma arte intelectualizada no presente. Desse modo, podemos pensar que a história da arte e o presente da arte começam a compartilhar de uma natureza em comum proveniente da fotografia.

Quando Picasso diz que a fotografia apenas liberta os artistas da necessidade de representar a natureza, não percebe que a fotografia, na realidade, inventou um outro passado para a arte que antes não existia. A representação renascentista, barroca, clássica, medieval, etc. nunca foram representações com características fotográficas: nenhuma delas se constitui como um índice pragmático ou carrega uma contiguidade referencial daquilo representado. As pinturas tradicionais nunca foram índices do mundo, pois são apenas representações simbólicas. Se a arte moderna rompeu com a tradição, não foi por que a fotografia ofereceu liberdade da neces- 
sidade de representar a natureza, pois a natureza antes nunca foi representada fotograficamente! Se a arte moderna rompeu com a tradição, foi por que a modificou anacronicamente. A fotografia, pelo contrário do que se diz, se estabelece como uma natureza em comum entre a arte tradicional e a arte moderna.

Duchamp pode ser o grande exemplo da presença do modo de agir fotográfico na arte. Mas, de modo geral, em toda arte contemporânea, podemos encontrar inúmeros casos. Da mesma forma que a arte moderna, se analisada como um bloco, buscou o desenvolvimento da abstração, a arte contemporânea, vista como um todo, buscou uma relação pragmática com o mundo para ter sentido. O artista contemporâneo baseia sua prática na lógica do índice, na contiguidade referencial e em atitudes pragmáticas provenientes da epistemologia da fotografia. Afinal, o nome "arte contemporânea" teria algum sentido sem essa ligação direta e "fotográfica" do fazer artístico com o mundo?

Dubois (1990/1993) ressalta que há os artistas que utilizam a fotografia devido à sua característica de marca física, traço, clichê, pois suas obras necessitam de uma ligação pragmática com o mundo para terem sentido, como Andy Warhol, David Hockney, Cristian Boltanski, até aqueles que, mesmo sem operar com a fotografia, cercam seus trabalhos por questões tipicamente indiciarias, como as impressões de corpo de Yves Klein ou Antony Gormely (entre muitos), o jogo de traços de Denis Oppenhein ou Claes Oldenburg, os cortes nos prédios abandonados de Gordon Matta-Clark, etc. E os parangolés de Hélio Oiticica, por exemplo, também se fundamentam na lógica do índice?

A performance (ou a experiência pictórica do parangolé, por exemplo), são um tipo de arte do corpo sentida no corpo e, após seu término, deixam de existir no tempo e no espaço. Nesse sentido, são práticas que elaboram seu sentido devido a essa ligação pragmática com o momento e o lugar onde aconteceram. Uma pessoa que dança usando um parangolé não pode transmitir essa experiência para outra: se você quer saber como é usar um parangolé, você precisa usá-lo de fato.

A prática da performance, nesse sentido, também retira seus fundamentos em um modo de pensar fotográfico. Da mesma forma que um acontecimento fotografado deixa de existir na realidade depois que a foto foi feita (Henri Cartier-Bresson tem apenas uma chance para fotografar os meninos brincando naquela rua daquela maneira), a performance, depois de realizada, deixa de existir. Podemos pensar que ela se comporta fotograficamente: só pode acontecer naquele lugar e naquele momento. Sem essa relação pragmática ou de contiguidade referencial com o lugar, com o momento (e com o corpo), a performance não faz sentido.

Podemos pensar, por outro lado, que a performance pode ser fotografada ou filmada e, assim, existir no tempo e no espaço. Entretanto, mesmo assim, a lógica do índice continua, mas agora "ao quadrado": a foto se torna o índice de uma performance que, por si só, se fundamenta na lógica do índice. Em alguns casos, o registro da fotografia pode até assumir o lugar da própria performance, 
como exemplificado na teoria dos non-sites de Robert Smithson ou como em todas performances realizadas sem a presença de público, apenas para os fotógrafos, chamadas fotos performativas.

De modo geral, podemos observar essa necessidade de ligação pragmática da arte com o lugar e momento que foi realizada no princípio fundamental da Land Art, das instalações artísticas no espaço arquitetônico, entre muitos outros tipos de arte "presenciais" e "espaciais".

As práticas conceituais, por sua vez, ao invés de usar o espaço artístico como lugar pragmático, tentam evidenciar o funcionamento interno da própria arte: "A contribuição da arte conceitual é provavelmente a reflexão sobre o significado da arte, e não sobre seu aspecto formal (...) Nós mal começamos a nos perguntar como arte absorve as ideias e de que forma estas contribuem para sua significação" (GOLDIN; KUSHER, apud CAUQUELIN, 2005, p. 105) ${ }^{13}$. Quando Joseph Kosuth expõe uma cadeira do lado da foto da cadeira e do texto descritivo dessa mesma cadeira está, assim, trazendo à superfície a relação entre fotografia, contiguidade referencial e intelectualização presente no campo da arte. De certa forma, a arte conceitual nos ajuda a entender como a epistemologia da fotografia está presente não apenas no fazer artístico, mas no próprio significado da arte.

13. apud CAUQUELIN, Anne. Arte Contemporânea: uma introdução. São Paulo, Martins Fontes: 2005. p. 105.
De acordo com Dubois (1990/1993), todas essas práticas de arte contemporânea "procedem diretamente da lógica indiciária [...], sempre fisicamente inscritas em situações referenciais determinadas e singulares, que admitem todo seu sentido nessa relação de contiguidade existencial com seu meio" (p. 114). Ou seja, sem a noção de contiguidade referencial a Land Art, a performance, as instalações no espaço, a arte conceitual e muitos outros tipos de arte não fazem o menor sentido: aquele trabalho foi elaborado para aquele lugar e para aquele momento, para entender aquela situação.

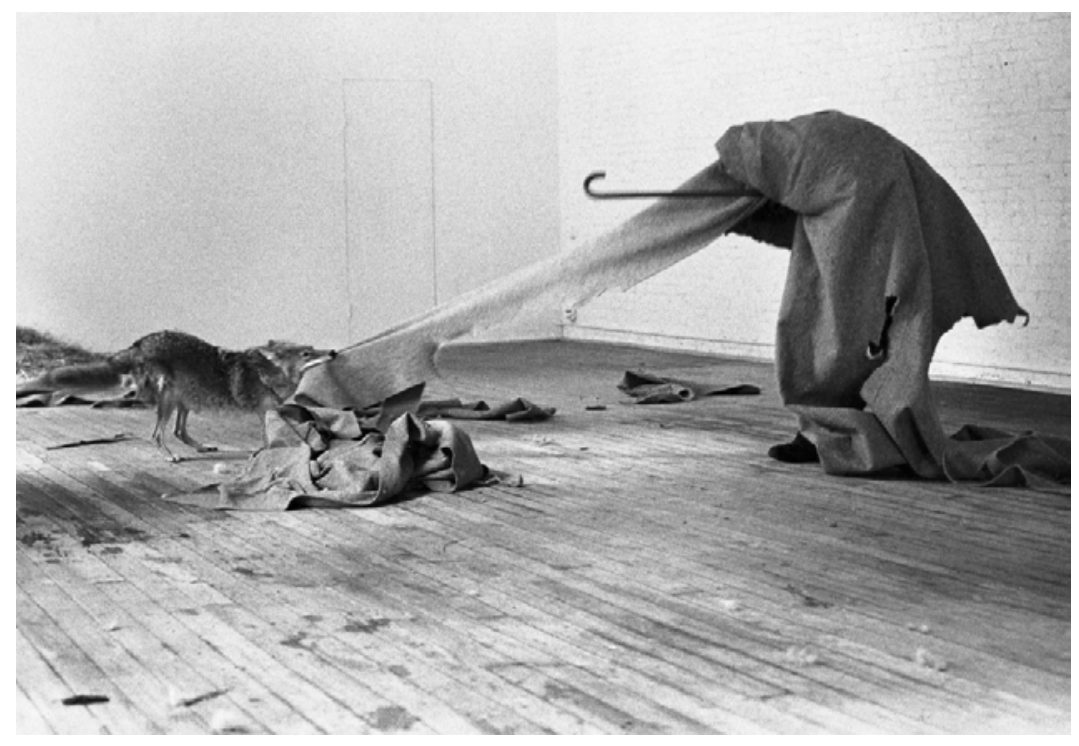

Figura 5: Performance "I Like America and America Likes Me" (1974) de Joseph Beuys.

Quanto mais a arte contemporânea se desenvolve, com a consolidação das instalações no espaço arquitetônico, com a difusão da arte conceitual, com o crescimento da prática da performance, 
quanto mais a arte contemporânea se dissemina, a lógica do índice fotográfico é utilizada de forma mais radical, a ponto de que a arte passa a existir apenas aqui e agora, para entender apenas a situação da atualidade, sem deixar rastros (a não ser rastros fotográficos), pois tudo é uma arte consumida, experimentada e vivenciada em uma circunstância pragmática determinada.

Vou citar quatro exemplos de obras realizadas no ano que este texto foi escrito (2013), mas poderia citar inúmeras! O primeiro, um trabalho de Paulo Nazaré: ele andou de chinelos de Belo horizonte até Nova York, para levar a sujeira do terceiro mundo no pés e deixá-las no rio Hudson. Esse trabalho só tem sentido pois ele efetuou essa caminhada de fato, durante meses, de modo pragmático, e realmente levou a sujeira nos pés (há fotos que comprovem isso). Essa "sujeira” não é simbólica, mas é, na termologia de Dubois (1990/1993), um exemplo de "contiguidade referencial" característico da epistemologia da fotografia e presente em trabalhos de arte fundamentados na lógica do indice. Paulo Nazaré é um dos artistas brasileiros que vai participar da Bienal de Veneza deste ano, uma das exposições mais importantes do mundo.

O segundo exemplo - que foi difícil de escolher entre tantos é a obra "Your Waste of Time" (2013) de Olafur Eliasson, exposta atualmente no MoMA PS1 - uns dos lugares de exposição de arte contemporânea mais importantes do mundo. Nessa obra, Eliasson expõe em uma sala climatizada grandes pedaços de gelo provenientes de uma geleira milenar da Islândia: se esses blocos de gelo não tivessem origem de fato nas geleiras, se não existissem como uma "contiguidade referencial" de outro lugar, se não se baseassem na pragmática da lógica do índice, essa obra não teria sentido. Não são gelos simbólicos, são gelos "fotográficos".

Como terceiro exemplo, cito Paul McCarthy. Em sua mais recente exposição em Nova York titulada "Live Cast" na galeria Hauser \& Wirth (2013) apresenta alguns bonecos de silicone realizados a partir do molde direto de uma modelo feminina, cuja reprodução inclui cabelos, manchas na pele e genitais fielmente reproduzidos. Além dessas peças funcionarem como um índice muito bem detalhado dessa pessoa em particular, no andar de cima, ele apresenta vídeos que mostram o processo da manufatura dessas peças e alguns dos moldes utilizados. De acordo com o pensamento de Dubois (1990/1993), a lógica dessa exposição como um todo utiliza a epistemologia do índice (e da fotografia) como parâmetro, pois se fundamenta na "impossibilidade de pensar o produto artístico sem nele inscrever também (e sobretudo) o processo do qual é resultado”. (p. 280). Há muitos artistas atuantes hoje que evidenciam o processo de manufatura da obra ou o processo da própria arte como parte significativa da obra.

Como último exemplo, cito Marina Abramovich. Ela recentemente anunciou a criação, em alguns anos, de um instituto que leva seu nome. De acordo com o vídeo institucional ${ }^{14}$, o visitante, ao chegar nesse lugar, sentará em uma cadeira, será aconchegado com

$\overline{\text { 14. Disponível em: }}<$ http://www.marinaabramovicinstitute.org/>. Acesso em: 07 jun. 2013. 
um cobertor e será levado para as salas de exposição totalmente introspectivas. A experiência de visitar esse instituto será baseada na impossibilidade de recriar essa vivência em outro lugar ou em outro tempo. Portanto, se baseia em uma relação pragmática com aquela situação específica e utiliza uma lógica do índice fotográfico altamente sofisticada.

Nesse sentido, a arte busca cada vez mais transportar elementos do mundo para o ambiente intelectualizado da arte, ou levar a prática artística para o próprio cotidiano. A arte e a vida passam a se misturar. No entanto, é a vida que se torna um gesto intelectualizado da arte, e não o contrário, pois a arte não se torna mundana. Nesse momento de intelectualização da vida, quando uma carta de amor se torna $\operatorname{arte}^{15}$, a lógica do índice, a contiguidade referencial e as atitudes pragmáticas características da epistemologia da fotografia se realizam completamente. Nas palavras de Dubois (1990/1993):

Como se, desde que a fotografia fez surgir no campo da arte uma nova relação da representação com o real, todo o trabalho dos artistas inovadores tivesse consistido (deliberadamente ou inconscientemente) numa espécie de corrida desenfreada rumo ao absoluto dessa lógica, rumo à ativação de um 'índice puro'. (p. 115)

Apesar da lógica indiciária ser tão clara e tão presente na noção de arte moderna e na prática de arte contemporânea, muitos não a

15. Como o trabalho "Take Care of Yourself" de Sofie Calle, apresentado na Bienal de Veneza de 2007. percebem pois, de certo modo, continuam a considerar (consciente ou inconscientemente) a fotografia como espelho do real e não percebem sua verdadeira influência.

Ainda hoje, no começo do século XXI, encontramos nos corredores das faculdades de ensino de artes o discurso de que a fotografia apenas liberou os artistas da necessidade de representação, e sua verdadeira influência na arte não está sendo levada em consideração. Será que não devemos abandonar esse discurso da "libertação da arte pela fotografia" de uma vez por todas e começar a considerar a arte moderna e contemporânea como dependentes e da natureza fotográfica? Cada artista cria sua própria obra, mas todos eles dependem da lógica da fotografia para que suas obras terem sentido. Mais uma vez, para concluir, nas palavras brilhantes de Dubois (1990/1993):

... [a obra de] Duchamp, por mais complexa e múltipla que seja, aparece bem, historicamente, como pedra de toque das relações entre fotografia e arte contemporânea, como lugar e o momento de reviravolta, em que se passa dessa ideia banal e tão frequentemente repetida segundo a qual a foto veio libertar a pintura de seus vínculos da representação 'icônica' a essa outra ideia, mais paradoxal e nova, segundo a qual a arte virá a partir de então extrair, das condições epistêmicas da fotografia, possibilidades singulares de renovação de seus processos criativos e de suas apostas estéticas principais. (p. 258).

Portanto, da forma apresentada acima, como jardineiro de arte, identifico a natureza onde estou inserido e que devo cultivar: uma natureza da arte formada tanto pela metamorfose provocada ana- 
cronicamente pela fotografia na arte do passado, através do museu imaginário, quanto pela influência substancial da lógica do índice fotográfico na arte recente. Nesse contexto, percebo conscientemente uma natureza da arte baseada na epistemologia da fotografia que se expandiu por toda história como uma planta rasteira e por todo presente como uma floresta. Enfim, apresento a natureza fotográfica da arte no qual estamos inseridos.
A Natureza Fotográfica da Arte: Futuro

A pergunta, então, não quer se calar: "por quanto tempo ainda iremos viver junto dessa natureza fotográfica da arte?” Se o passado de toda história foi "transformado" e adquiriu qualidades da fotografia, se toda arte do presente se desenvolveu de acordo com uma lógica fotográfica, conseguiremos sair no futuro desse "trilho fotográfico" que já está muito bem estabelecido?

A resposta para essa pergunta é: muito provavelmente não - ainda viveremos fotograficamente por muito tempo. De acordo com o filósofo Vilém Flusser ${ }^{5}$ não apenas a arte, mas a sociedade como um todo, incluindo os seus mecanismos de produção e funcionamento, utilizam o aparelho fotográfico como matriz.

O aparelho fotográfico pode servir de modelo para todos os aparelhos característicos da atualidade e do futuro imediato. Analisá-lo é método eficaz para captar o essencial de todos os aparelhos, desde os gigantescos (como os administrativos) até os minúsculos (como os chips), que se instalam por toda parte. Pode-se perfeitamente supor que todos os traços aparelhísticos já estão prefigurados

5. FLUSSER, Vilém. A Filosofia da Caixa Preta: Estudos para uma Futura Filosofia da Fotografia. São Paulo: Hucitec, [1983] 1985. 
no aparelho fotográfico, aparentemente tão inócuo e 'primitivo'. (FLUSSER, 1983/1985, p. 13)

Como isso pode acontecer?

Em primeiro lugar, devemos lembrar que a imagem fotográfica é uma imagem técnica e não uma imagem tradicional como a pintura. Ou seja, é uma imagem produzida por um aparelho. Esse tipo de imagem aparentemente é uma consequência direta do mundo; em uma fotografia de uma paisagem, parece que a paisagem se imprimiu diretamente ali, sem intermediários. Já em uma imagem tradicional, como uma pintura dessa mesma paisagem, por exemplo, é fácil perceber que se trata de uma imagem "indireta", pois fica claro que há um agente humano, o pintor, entre a imagem e o mundo. Entretanto, na fotografia vemos apenas o que entra (input) e o que sai (output) do aparelho e, dessa forma, não percebemos o que se passa em seu interior, em sua caixa preta. Flusser (1983/1985) se dedica a "branquear" essa caixa preta com a finalidade de revelar o seu funcionamento interno (e, consequentemente, de toda sociedade atual formada por aparelhos).

Nesse contexto, o aparelho fotográfico que produz essa imagem "direta”, não é, por sua vez, um instrumento para modificar o mundo como, por exemplo, uma enxada. O aparelho fotográfico funciona de acordo com um programa independente. Um fotógrafo, quando fotografa, não modifica o mundo lá fora, mas apenas tem interesse de usar o mundo para alimentar esse aparelho e seu programa de funcionamento. O fotógrafo, de acordo com Flusser
(1983/1985), trabalha em função do aparelho.

Ele diz isso porque as fotografias são realizações de algumas potencialidades do aparelho fotográfico e de seu programa e não "criações do fotógrafo". Este fotógrafo, por melhor e mais criativo que seja, nunca vai conseguir realizar todas as fotografias fotografáveis por seu aparelho. De certo modo, o aparelho fotográfico tem a potencialidade de gerar muito mais fotos do que o fotógrafo tem capacidade de realizá-las. Ou seja, o fotógrafo que crê estar escolhendo o que fotografar livremente, na realidade, só pode "fotografar o fotografável", só pode fotografar cenas e nunca processos. Só está atuando dentro dessa infinita potencialidade que o aparelho fotográfico e seu programa lhe oferecem.

O fotógrafo, em sua defesa, pode, antes de fotografar, recorrer a critérios alheios ao aparelho. Escolhe se vai fazer uma fotografia politicamente engajada, esteticamente bela, etc. Mas, independentemente do que escolher, terá que adequar a cena política ou a cena estética aos moldes da fotografia para depois fotografar. Ou seja, ele precisa antes transformar essas cenas em conceitos para depois poder apertar o botão (cria o conceito de aniversário para depois escolher o que fotografar; "registra" o momento mais representativo da ideia daquele momento - no caso, quando a vela é assoprada). E isso é muito perigoso, pois quando vemos uma fotografia e achamos que estamos vendo o mundo diretamente, na realidade estamos vendo conceitos do mundo, estamos vendo "textos" que significam cenas do mundo e não percebemos isso. Não percebemos o que ocorre dentro da caixa preta. 
Nesse sentido, não percebemos que, quando vemos imagens fotográficas ignoramos completamente o fato de essas imagens serem constituídas por textos e conceitos, e não de "imagens diretas do mundo". Isso fica claro quando apontamos o dedo para uma foto da praia falamos "estou aqui pulando onda" e não "essa foto é apenas um índice do meu pular de ondas na praia, pois, no momento, eu não pulo mais onda lá". Nesse "atalho" que fazemos para acreditar na fotografia, ignoramos que estamos vendo apenas um conceito desse pular na praia e eliminamos, nesse processo, todo o "texto" ali presente. Com isso, não deciframos a fotografia, não percebemos sua constituição conceitual e, assim, a vemos apenas como magia . Desse modo, trocamos o "pensamento linear" característico dos conceitos, dos textos e da história por uma "pensamento circular" característico das imagens cujo funcionamento é baseado no eterno retorno. Ou seja, posso ver a mesma fotografia inúmeras vezes e falar em todas elas no presente "estou aqui pulando onda", como se o tempo não tivesse passado, como se a história não mais existisse.

O tempo linear é característico da linguagem escrita e da consciência histórica, no qual os fatos acontecem e tornam-se história. Entretanto, na fotografia os fatos acontecem e, devido ao seu tempo circular, entram no ciclo do eterno retorno, e passam a se repetir eternamente. Quando agimos para a fotografia, queremos ser fotografados para "eternizar" o momento. Não mais pensamos

6. Como imagem. historicamente em uma linha que perpassa o passado, o presente e o futuro, mas já agimos considerando que o presente irá se repetir no futuro que, então será redundante. Entramos em um ciclo infinito e repetitivo. Nesse sentido, fotografamos não para criar história, mas para criar futuro.

Tudo, atualmente, tende para as imagens técnicas, são elas a memória eterna de todo empenho. Todo ato científico, artístico e político visa eternizar-se em imagem técnica, visa ser fotografado, filmado, videoteipado. Como a imagem técnica é a meta de todo ato, este deixa de ser histórico, passando a ser um ritual de magia. Gesto eternamente reconstituível segundo o programa. (FLUSSER, 1983/1985, p.12)

Nesse jogo há uma inversão: o mundo só passa a existir depois que foi fotografado, pois antes é só uma virtualidade ou uma possibilidade do aparelho fotográfico. Agimos para a fotografia. A praia só passa a existir depois que é fotografada. O aniversário do seu filho só se realiza nas fotografias. O casamento entre duas pessoas só se concretiza quando fotografado. Se não fotografamos um evento, ele deixa de existir. Se não fotografamos uma obra de arte ela não tem a chance de entrar para "história". E é exatamente assim que começa o controle do aparelho fotográfico sobre a vontade humana.

De acordo com Flusser (1983/1985): "O fotógrafo domina o aparelho, mas pela ignorância dos processos no interior da caixa preta, é por ele dominado" (p. 15). A realidade deixa de existir enquanto fenômeno livre e passa a ser uma mera consequência 
das potencialidades do aparelho, passa a ser uma consequência do "programa fotografia". Ou seja, de um lado há a intenção do fotógrafo e do outro a "intenção do aparelho": o fotógrafo quer fotografar cenas "novas" para criar "história" (que não passa de um futuro redundante), e o aparelho "quer" que um fotógrafo realize seu programa. Mas, como todas as fotos "novas" do fotógrafo estarão sempre contidas na potencialidade do aparelho, pois só é possível "fotografar o fotografável” de acordo com o programa oferecido, esse fotógrafo nada mais é do que um "funcionário" que executa algo pré-determinado.

Nesse sentido, o fotógrafo que pensa estar agindo livremente, está na realidade agindo de acordo com o "programa fotografia" e, sem liberdade, trabalha para dar corda nesse círculo vicioso entre fotografia e realidade. Alimentamos o aparelho para ele nos alimentar. Fotografamos para "gerar realidade" mas, ao mesmo tempo, criamos uma realidade baseada nas características da fotografia. Ou seja, criamos uma realidade fotográfica onde o pensamento linear da história é substituído por um pensamento circular redundante, automático e absurdo. Nas palavras de Flusser (1983/1985):

A hipótese aqui defendida é esta: a invenção do aparelho fotográfico é o ponto a partir do qual a existência humana vai abandonando a estrutura do deslizamento linear, próprio dos textos, para assumir a estrutura de saltear quântico, próprio dos aparelhos. O aparelho fotográfico, enquanto protótipo, é o patriarca de todos os aparelhos. Portanto, o aparelho fotográfico é a fonte da robotização da vida em todos os seus aspectos, desde os gestos exteriorizados ao mais íntimo dos pensamentos, desejos e sentimentos. (p. 36)
É por isso que somos "funcionários" do "programa fotografia", pois vivemos fotograficamente de acordo com suas possibilidades, e não vice-versa. Os aparelhos nos oferecem um modo de viver já definido.

A caixa preta que está no interior dos aparelhos é o local onde esse programa se executa. Entretanto, a caixa preta não está apenas no interior do aparelho fotográfico, está no interior de todos os aparelhos: industriais, publicitários, econômicos, políticos, administrativos, etc. Cada um funciona automaticamente e alimenta a caixa preta do outro; o aparelho fotográfico alimenta o aparelho do parque industrial, que alimenta o aparelho da economia, que alimenta o aparelho político, e assim por diante. Vivemos não mais na bistória, mas apenas como funcionários desse enorme conjunto de aparelhos que, de tão grande, ninguém mais controla; nossas "decisões" passam a ser funcionais, tomadas ao acaso com o simples objetivo de fazer o programa desses aparelhos funcionar (válido do caixa do banco até o presidente dos Estados Unidos). 
O Sistema Fotográfico da Arte

Nesse ponto do presente texto, os três autores, Malraux, Dubois e Flusser se encontram. De acordo com Malraux (1965/2000), o passado da história da arte foi transformado anacronicamente e adquiriu qualidades fotográficas. De acordo com Dubois (1990/1993) o presente da arte foi construído, consciente ou inconscientemente, a partir da epistemologia da fotografia. E agora, de acordo com Flusser (1983/1985), o futuro não apenas da arte, mas de toda vida, também será fotográfico, pois abandonamos o tempo linear característico da história a agora vivemos em um tempo circular e automático característico da fotografia: nossas ações são realizações de potencialidades já inscritas no aparelho, no qual estamos apenas realizando um programa que já está determinado e tende ao eterno retorno.

A única solução, na visão de Flusser (1983/1985), de conseguir sair desse "programa fotografia" já profundamente enraizado em nossa sociedade é o "branqueamento da caixa preta", tomar consciência desses programas e, consequentemente, desenvolver uma filosofia da fotografia para "se viver livremente num mundo programado por aparelhos". (p. 41)
Assim, me pergunto com muita curiosidade: se a arte moderna e contemporânea extraiu "das condições epistêmicas da fotografia, possibilidades singulares de renovação de seus processos criativos e de suas apostas estéticas principais" (DUBOIS, 1990/1993, p. 258), será que essa arte baseada na lógica da fotografia é apenas parte do "programa fotografia" descrito por Flusser e, assim, mera realização de uma das potencialidades de um universo fotográfico pré-determinado? Ou, sob um ponto de vista contrário, será a arte uma possibilidade de "branquear a caixa preta" e, assim, um modo de liberdade perante o "programa fotografia"? Será o artista um mero funcionário desse programa ou será o artista uma espécie de filósofo da fotografia?

De um lado, Dubois (1990/1993) afirma que a arte moderna e contemporânea retiraram das condições epistêmicas da fotografia as suas possibilidades de renovação e suas apostas estéticas principais. Ao mesmo tempo, realizam esse processo, sem necessariamente o uso do aparelho fotográfico, podendo este processo também se dar através da pintura, da escultura, etc. Será que, por isso, essa arte está desvinculada do "programa fotografia" e, assim, funciona com liberdade?

Por outro lado, Flusser (1983/1985) afirma que os aparelhos fotográficos são modelos de todos aparelhos, desde os gigantescos (como administrativos) até os minúsculos (como os ships). Nesse sentido, mesmo que a arte, muitas vezes, não utiliza o aparelho fotográfico para produzir suas obras, ainda assim, poderia estar inserida num "aparelho-arte", no qual agem sem liberdade em função 
de um programa pré-determinado.

Ou seja, ao analisar retroativamente a arte moderna e contemporânea, será que o artista ao utilizar a "lógica do índice" descrita por Dubois está sujeito ao "programa fotografia" descrito por Flusser? Será que a "lógica do índice" é sinônimo do "programa fotografia"? Se ambos puderem ser interpretados da mesma maneira, indicará que a arte é mera realização do "programa fotografia". Mas, se a "lógica do índice" funcionar de modo independente do "programa fotografia", isso indicará que os artistas podem ser considerados como filósofos da fotografia, pois "pensam fotograficamente" de modo livre, sem estarem presos a um programa. Vamos averiguar.

O "programa fotografia" basicamente funciona ao esconder o que acontece no seu interior. Ele tem sucesso, pois justamente aparenta não existir. Assim, não pode ser localizado e nem modificado. "Um sistema assim tão complexo é jamais penetrado totalmente e pode chamar-se caixa preta" (FLUSSER, 1983/1985, p. 15). Ele nos controla devido à sua capacidade de eliminar o pensamento linear e substituir por um pensamento circular, onde caímos no ciclo do eterno retorno. Já a "lógica do índice" usada como fundamento para a arte não se esconde, não tenta passar despercebida. Pelo contrário, os artistas evidenciam o processo de criação como principal significado da obra. Eles se esforçam para evidenciar o funcionamento da arte.

Van Gogh, por exemplo, deixa evidente que uma pintura é feita de pinceladas. Mondrian mostra a "superfície plana, a forma do suporte, as propriedades das tintas" (GREEMBERG, 2001, p. 102) 5 . Toda arte moderna, de um modo ou de outro, buscou evidenciar os mecanismos da arte como parte significativa da obra ${ }^{6}$. A arte contemporânea, por sua vez, não faz diferente. Duchamp e arte conceitual evidenciam o funcionamento da arte ${ }^{7}$, Chris Burden e muitos outros artistas que praticam a performance deixam claro que o artista faz parte da obra, Nelson Lerner juntamente com o grupo REX questionam o próprio funcionamento do mercado e do circuito da arte, entre inúmeros exemplos.

De modo geral, a arte, em todo seu percurso, não permanece no interior da caixa preta, não tenta esconder os seus mecanismos internos de funcionamento ou do sistema que está inserida, mas, ao invés, se esforça para deixa-los à mostra.

Portanto, a "lógica do índice" utilizada na arte moderna e contemporânea não é sinônimo do "programa fotografia" característico dos aparelhos, pois evidencia os processos pelo o qual são feitas,

\footnotetext{
5. GREEMBERG, Clement. Clement Greemberg e o debate crítico. Rio de Janeiro: Jorge Zahar ed., 2001.

6. Sobre esse assunto, ver: TASSINARI, Alberto. O Espaço Moderno. São Paulo: Cosac Naify, 2001.

7. Anne Cauquelin diz "portanto, assim como os jogos de linguagem de Wittgenstein esclarecem não a mensagem, mas o sistema da língua e seu uso, as proposições de Duchamp que acrescentam aos ready-mades (...) esclarecem não tanto os próprios objetos - cujo significado habitual tendem antes a obscurecer - e sim o funcionamento da arte.” In: CAUQUELIN, Anne. Arte contemporânea: uma introdução. São Paulo: Martins Fontes, 2005. p. 102.
} 
ao invés de tentar escondê-los. Ou seja, os artistas "pensam fotograficamente", mas não "agem programadamente".

Assim, só nos resta afirmar: os artistas modernos e contemporâneos podem ser considerados como praticantes da filosofia da fotografia no sentido flusseriano, mesmo que não tenham se dado conta disso. Eles utilizam a epistemologia da fotografia para alimentar seus fundamentos principais, mas de modo livre. Eles não estão sujeitos ao programa obscuro da caixa preta que esconde seus mecanismos de funcionamento, mas, ao invés, tentam branqueá-la, pois justamente geram significado para arte ao evidenciar as questões processuais que ali estão envolvidas.

Diante desses pressupostos, será que podemos considerar a arte moderna e a contemporânea como um lugar fértil para o desenvolvimento da filosofia da fotografia? Será esta a função obscu-

\section{ra da arte?}

Podemos ver uma pintura abstrata e ou uma performance e pensar: 'aqui podemos observar a fotografia em seu estado de liberdade, agindo conforme suas qualidades epistêmicas de forma autônoma, sem mais a necessidade de se relacionar com o programa vicioso da fotografia, portanto, de maneira livre, intrínseca e filosófica'. Assim, podemos considerar cada obra de arte como fonte para conhecer mais profundamente a natureza da fotografia e também como meio para que essa natureza se apresente crua, como ela realmente é.
Podemos apresentar esse pensamento de outro modo: quando vemos uma fotografia de uma flor, por exemplo, achamos involuntariamente que vemos a própria flor. Falamos "olha que flor bonita". Mas, se ao olhar a fotografia, só percebemos aquilo que está do outro lado da foto, se só percebemos os objetos que foram fotografados, ao mesmo tempo, não percebemos a fotografia em si, não percebemos os elementos que são necessários para criar essa "ilusão", não percebemos a epistemologia fotográfica envolvida nesse processo, não percebemos a "caixa preta" flusseriana, pois só percebemos a flor. Assim, onde podemos perceber todas essas outras coisas? Onde podemos perceber qual é a epistemologia da fotografia ou o que está dentro da "caixa preta"?

Proponho que podemos perceber todas essas outras coisas na arte, mesmo em obras que não utilizam a fotografia como meio. Pois, na arte, o modo de pensar fotográfico está presente, mas sem ser coagido pelo programa flusseriano do aparelho fotográfico, sem estar encoberto pela "ilusão" da fotografia, mas sim de forma pura, autônoma e livre. Ou seja, o artista quando consegue trazer à superfície mais um elemento do programa que está inserido, faz arte. Podemos dizer que antes do início da arte moderna o "programa-arte" era uma caixa preta. No decorrer do desenvolvimento da arte moderna e contemporânea, esse programa foi se branqueando e, hoje, já é um “cinza”. Cada artista, ao mostrar mais um elemento processual da arte, amplia nossa consciência sobre esse sistema, até que, em um dado momento, poderemos compreendê-lo por inteiro. 
Ligia Clark, por exemplo, quando cria seus bichos na década de 1960, no qual o espectador pode manusear a escultura e reconfigurá-la em diversas posições, pode ser interpretado, no ponto de vista da filosofia da fotografia, como um comentário sobre o mundo programado em que vivemos. Da mesma forma que na filosofia flusseriana os aparelhos fotográficos possuem virtualmente todas as fotos possíveis de serem fotografadas, os bichos de Ligia Clark funcionam de acordo com um programa pré-determinado, pois todas as posições possíveis da escultura já estão virtualmente contidas na obra. A obra de Ligia Clark nos mostra o que está latente dentro da caixa preta e, assim, nos oferece um exemplo visual que pode ser usado para entender mais sobre o prório funcionamento obscuro da fotografia.

Da mesma forma, o discurso sobre o minimalismo, por exemplo, também pode ser entendido como um discurso sobre o branqueamento da caixa preta da fotografia. Não é coincidência que tanto a fotografia quanto o minimalismo são particularizados por serem produtos elaborados sem a mão humana, fruto de uma indústria, cujo resultado pode ser reproduzido inúmeras vezes. A mecanicidade do minimalismo é um dos elementos do interior obscuro da caixa preta flusseriana. Ao pensar a história da arte moderna e contemporânea sob o ponto de vista da filosofia da fotografia, ela ganha um novo sentido. Ela deixa de ser uma história que busca apenas ampliar o território da arte e passa a ter uma função: revelar qual é a natureza da fotografia.

Nesse sentido, ao mesmo tempo que cada artista, cada um do seu jeito, evidencia o funcionamento do sistema que está inserido, sem perceber, oferece modos de visualizar qual é a natureza que está dentro da caixa preta fotográfica. Se a arte moderna e contemporânea for analisada sob o ponto de vista da filosofia flusseriana, será revelada muita coisa sobre a própria natureza da fotografia que ainda não sabemos ${ }^{8}$.

$\mathrm{Na}$ arte moderna, a epistemologia da fotografia está presente, no plano das ideias, na noção metalinguística e autônoma da arte. $\mathrm{Na}$ arte contemporânea, além disso, está presente no próprio fazer artístico, de modo que os artistas retiram da lógica do índice suas apostas mais inovadoras e o seus modos de agir. Durante o desenvolvimento da arte moderna e contemporânea, portanto, o pensamento sobre a fotografia, com o passar do tempo, se tornou mais amplo e complexo.

Podemos deduzir que a arte funciona dentro de um grande sistema fotográfico que se auto-alimenta e que, de certa forma, passa a funcionar como uma natureza independente. Não podemos esquecer que as obras de arte modernas e contemporâneas também foram fotografadas, também foram impressas em livros, dispostas em websites e, de maneira global, também ingressaram no museu imaginário proposto por Malraux.

8. Dubois desenvolveu a noção epistemológica da fotografia concomitantemente com o desenvolvimento da arte contemporânea. Foi ali que esse pensamento se revelou. 
Cria-se assim um sistema fotográfico de arte: quanto mais a arte utiliza a epistemologia da fotografia em seus fundamentos, mais facilmente se tornará parte do museu imaginário, mais servirá de referência para os novos artistas fazerem arte, criando um ciclo.

Ou seja, quando uma obra é fotografada, ela ingressa no museu imaginário, perde sua função de origem e se intelectualiza. Com isso, evidencia, dentre todas suas qualidades, aquelas com alguma relação com o modo de pensar fotográfico, pois estas podem ser transportadas para esse "museu formado por fotografias" sem perder conteúdo. Se em uma obra a lógica do índice está presente de forma tímida, no museu imaginário essa lógica vai ganhar destaque, pois se evidencia e se pontecializa ao ser reproduzida por uma linguagem de natureza indicial. A partir de então, essa obra transformada pelo museu imaginário passa a servir de referência para novos artistas que, por sua vez, terão suas obras fotografadas.

Diante desse cenário, os artistas podem criar obras totalmente contra a fotografia, "obras infotografáveis", como resposta a essa intelectualização presente no museu imaginário. Assim, criam uma pintura que evidencia a tinta de que é feita, uma performance que gera um sofrimento real, uma instalação que só pode ser vista naquele lugar e naquele momento, ou qualquer tipo de arte que "não pode ser vivenciada através de sua reprodução fotográfica" ${ }^{\prime 9}$. Mas que, na verdade, como dito anteriormente, se fundamenta em uma lógica do índice cada vez mais radical. Ou seja, quanto mais o artista tenta escapar da lógica da fotografia, mais afunda nela. Quanto mais tenta negar a fotografia, mais a fortalece.

E assim, nesse ciclo de vida e morte da fotografia, cria-se um sistema que se auto alimenta para formar uma natureza da arte cada vez mais fotográfica. Cada nova obra de arte utiliza, de um novo modo, a epistemologia da fotografia como fundamento e, simultaneamente, evidencia os processos ali envolvidos. Aos poucos, essa epistemologia da fotografia se torna mais complexa - pois o museu imaginário não aceita ideias repetidas. Ao poucos, o terreno da filosofia da fotografia se amplia e, consequentemente, se forma uma natureza fotográfica da arte cada vez mais presente.

Dito tudo isso, em síntese, apresento um outro modo de entender a arte moderna e contemporânea: lugar onde se manifesta liberdade para a prática da filosofia da fotografia por meio da expressão artística, no qual, simultaneamente, se realiza a natureza fotográfica da arte.

9. Como fica muito evidente nas performances de Tino Sehgal, vencedor do leão de ouro de melhor artista da bienal de Veneza de 2013, no qual o maior significado de sua obra não é a performance em si, mas o fato de não poderem ser fotografadas ou filmadas; só podem existir como memória daqueles que a presenciaram. 


\section{CONCLUSÃo}

Propomos, inicialmente, que a natureza da arte não é apenas a história das relações entre arte e natureza sugerido por Ribon. Mas, é algo mais primordial, que fundamenta a noção de arte de obras da história e do presente.

Em seguida, elaboramos a ideia de uma natureza fotográfica da arte baseada nos livros "O Museu Imaginário" de André Malraux e "O Ato Fotográfico" de Philippe Dubois. Malraux descreve como a fotografia influenciou de modo anacrônico a noção de arte do passado pois, adquiriu qualidade fotográficas e se tornou, principalmente, uma noção de arte intelectualizada. Dubois, por sua vez, comenta como a lógica do índice fotográfico influenciou o percurso da arte moderna e da arte contemporânea, de modo que extraíram seus principais fundamentos da epistemologia da fotografia.

Em seguida, utilizando como base os pensamentos de Vilém Flusser encontrados em seu livro "A Filosofia da Caixa Preta, Estudos para uma Futura Filosofia da Fotografia", problematizamos o futuro dessa natureza com qualidades fotográficas em que não só a arte está inserida, mas também a sociedade em geral.
Para finalizar, estabelecemos conexões entre o pensamento de Malraux, Dubois e Flusser, e delimitamos um novo campo de reflexão: considerar a arte moderna e contemporânea como manifestações da liberdade de se "pensar fotograficamente" e, portanto, lugar onde se praticou a filosofia da fotografia.

Desse modo, traçamos um panorama da real influência da fotografia na arte e na sociedade abrangendo, de certo modo, nossa história, presente e futuro como um todo. 
Parte 2: Reflexão sobre a Produção Artística 
Desde o início de minha trajetória no campo da prática artística, primeiramente de forma intuitiva e agora de forma teórica, tenho consciência da existência da natureza fotográfica da arte. Ao longo dessa segunda parte do texto, vou apresentar, em ordem cronológica, meus trabalhos realizados entre 2000 e 2013. Eles são frutos diretos dessa natureza em desenvolvimento.

Desde o início me encontro num lugar dominado pelo programa da fotografia e tento, gradativamente, me desvincular dele, esbranquiçar a caixa preta e encontrar liberdade dentro desse mundo absurdo. Ou seja, cultivo com o meu trabalho o campo da filosofia da fotografia.

Para tanto, apresento as etapas que realizei para me desvincular da técnica determinista da fotografia: inicialmente fotografei sem o aparelho fotográfico, em seguida sem a imagem técnica e, por último, sem o ato de fotografar.

Ao mesmo tempo, além de me afastar do programa da fotografia, tento me desvincular de sua lógica indiciária para desenvolver uma outra forma fotográfica de pensar, baseada, então, em seu caráter simbólico. Assim, pretendo gerar uma possibilidade para a 
fotografia significar relações de qualquer natureza, e não apenas aquelas com caraterísticas de índice pragmático e de contiguidade referencial. Ou seja, pretendo ampliar o domínio da liberdade e da filosofia da fotografia.

Nesse intuito, apresento algumas maneiras que encontrei para desenvolver uma epistemologia da fotografia baseada em seu caráter simbólico, e não mais em sua condição pragmática: pensar a fotografia como cultura e, para finalizar, fotografia como escrita.

Assim, na condição de jardineiro de arte, me proponho a cultivar a natureza fotográfica da arte com o objetivo de torná-la mais viva, livre e filosófica.
A Fotografia SEM O

Aparelho Fotográfico

(Análise da produção artística entre 2000 e 2002)

No verão de 2000 quando tinha 15 anos fui viajar para Maracajaú, perto de Natal, RN. Levei comigo uma Nikon F3 que era de meu pai. Por telefone, minha irmã me ensinou a operá-la e a controlar a luz de acordo com o fotômetro interno da câmera. E foi assim que comecei a fotografar.

De volta, já em São Paulo, ampliei essas fotos no tamanho 10x15 e montei meu primeiro álbum de fotos misturado com poesia. Desde esse primeiro momento, entendi a fotografia como algo maior do que um registro e mais poético do que um simples instante de mimese do mundo.

Fiz mais algumas "viagens fotográficas", como também fotografei meus amigos na escola. Mas foi em casa, por uma vontade extrema de experimentação, que desenvolvi meus trabalhos mais interessantes. Inicialmente, inventei algumas técnicas de múltipla exposição no mesmo negativo (uma vez que a Nikon F3 permite esse recurso) e fotografei detalhes da minha cozinha e dos objetos de forma que estes se transformavam em abstração. 


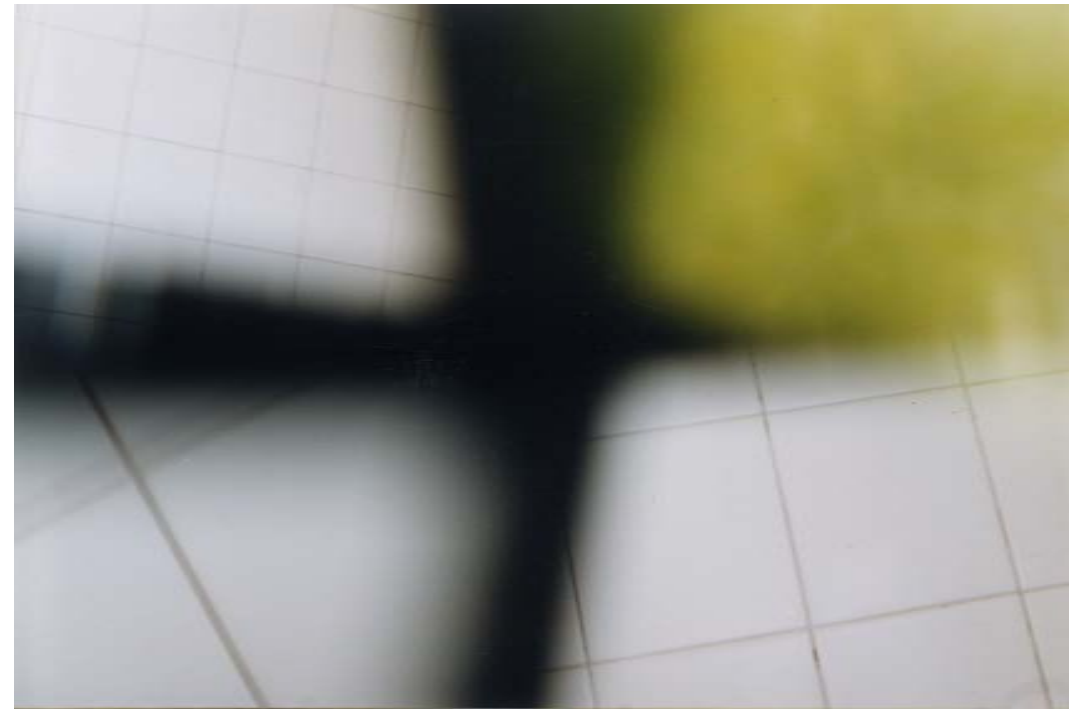

Figura 6

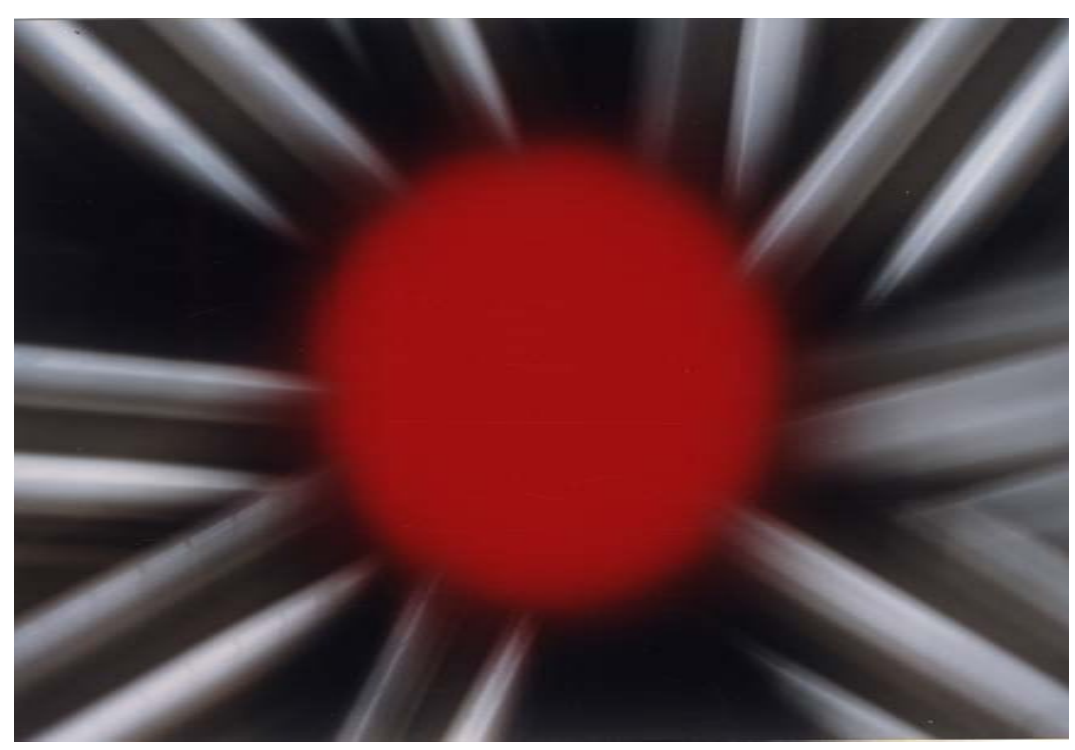

Figura 7
Para realizar essas imagens criei um sistema de janelas de papelão sobre a lente da câmera, a partir do qual podia sensibilizar apenas uma área do negativo de cada vez, e depois outra, por quantas vezes fossem necessárias. Na primeira imagem (figura 6) fotografei quatro vezes os azulejos da minha cozinha, na segunda (figura 7) fotografei nove vezes as lâmpadas fluorescentes do teto e uma vez um objeto vermelho. Assim, o aparelho fotográfico que geralmente é um "olho cíclope" se transformou em um "olho com várias facetas, vários tempos e várias possibilidades”. Apesar de neste momento ainda usar o aparelho para fotografar, subverti a sua forma convencional de uso.

Nesses trabalhos eu já buscava por algo que a fotografia de registro não me oferecia. Necessitava desenvolver um tipo de fotografia mais primária, mais essencial, mais próxima de sua gênese e mais longe de seu programa.

Havia uma necessidade de expandir ao máximo as possibilidades da fotografia. Assim, comecei a transformar a própria matéria fotoquímica da fotografia para fazer fotografia. Usava papéis velados e revelados para fazer escultura, ou raspas de emulsão fotográfica para fazer slides. Desse modo, desenvolvia todo tipo de experimentação com a substância constituinte da fotografia. Por exemplo, um metro quadrado de papel velado era riscado com facas, estiletes e agulhas ${ }^{5}$ (figura 8), ou eram confeccionadas imagens através

5. O que muitas vezes foi feito com os amigos da escola nas viagens de estudo do meio durante o Ensino Médio. 
da meticulosa tarefa de retirar camada por camada de um filme velado e remontá-las sobre uma base transparente (figura 9).

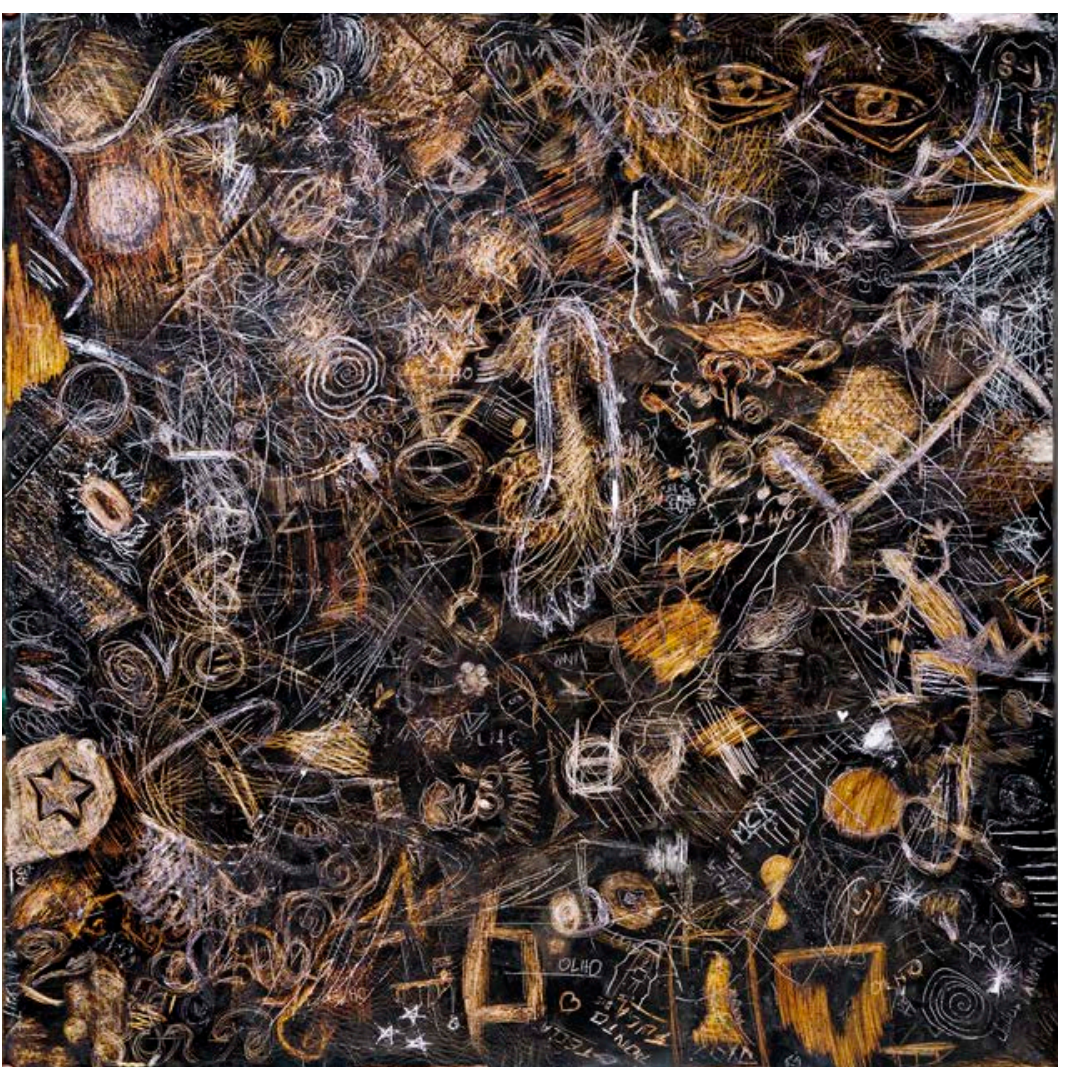

Figura 8

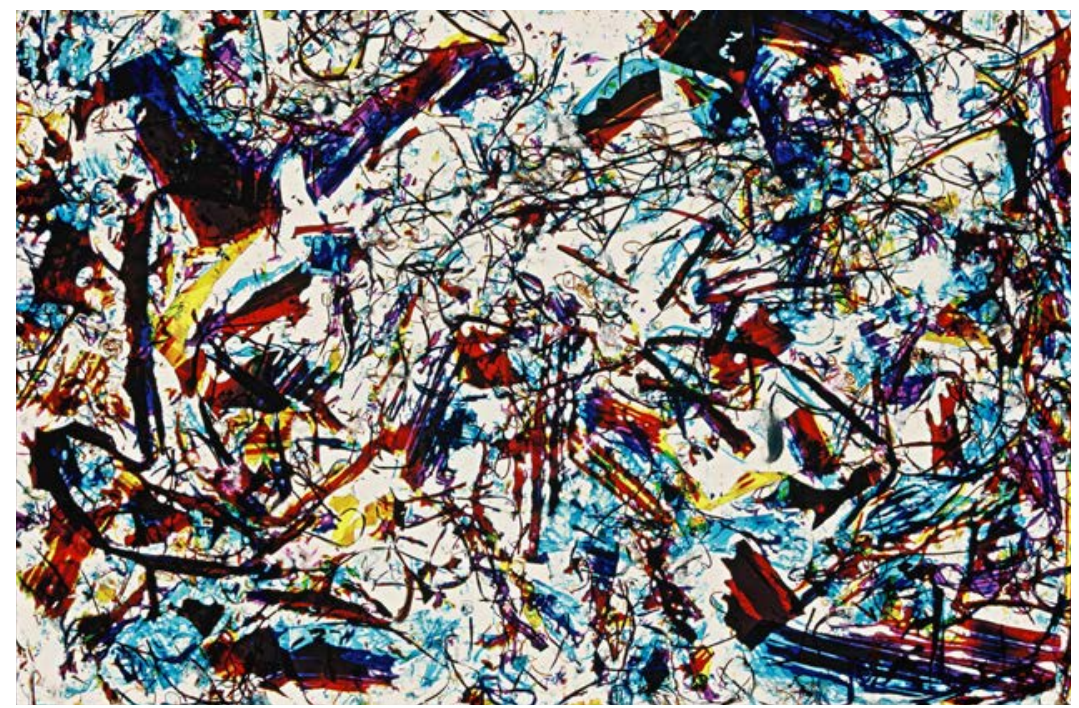

Figura 9

Nesse momento o aparelho fotográfico já estava há muito tempo sem uso, mas nem por isso, nesse aprendizado sobre os limites da fotografia, deixei de "fotografar". Aos poucos, comecei a desenvolver uma série de fotografias sem o uso do aparelho fotográfico.

Os próximos passos foram os fotogramas: comprava direto do fornecedor rolos inteiros de papel fotográfico colorido virgem e todos os químicos necessários para sua revelação e fixação caseira (no processo colorido realizam-se dois banhos químicos, mais a lavagem). O fotograma, talvez, seja o momento mais próximo que se pode chegar da essência fotográfica por meio da técnica, assim como outrora afirmou Làszlo Moholy-Nagy em seus escritos teó- 
ricos: "o fotograma é a própria essência da fotografia", ou ainda Rosalins Krauss: “O fotograma não faz mais que estender até o limite ou tornar explícito o que é verdadeiro para qualquer fotografia: toda fotografia é o resultado de uma impressão física que foi transferida para uma superfície sensível pelas reflexões da luz ${ }^{7}$ " (1977, apud DUBOIS, 1990/1993, p. 70).

De todas tentativas que fiz, realizei duas mais significativas que apresento a seguir. A primeira se deu pela vontade de eliminar qualquer intermediação entre a luz e o papel fotográfico. Desse modo, além de fazer um fotograma sem o uso do aparelho fotográfico, busquei uma fonte de luz que também não fosse proveniente de aparelhos. Que luz poderia ser esta? Assim surgiu a ideia de usar a luz de vaga-lumes. Depois de muito trabalho para achar vaga lumes em São Paulo ${ }^{8}$, estendi um papel fotográfico no chão de meu estúdio e soltei os pequenos besouros luminosos para andar sobre ele (figura 10). Os vaga-lumes se acendiam randomicamente e o papel fotográfico registrava essa "luz da natureza". Acontecia um momento selvagem entre a fotografia e a natureza.

\footnotetext{
6. apud Dubois, 1993,p. 71.

7. apud Dubois, 1993 , p. 70

8. Nessa busca, quase fui preso quando o policial me achou vagando devagar, com as luzes do carro apagadas no meio da rua Mercedes na Lapa, e perguntou "o que está fazendo?" e respondi com toda sinceridade do mundo: "estou caçando vaga-lumes sr. Guarda."
}

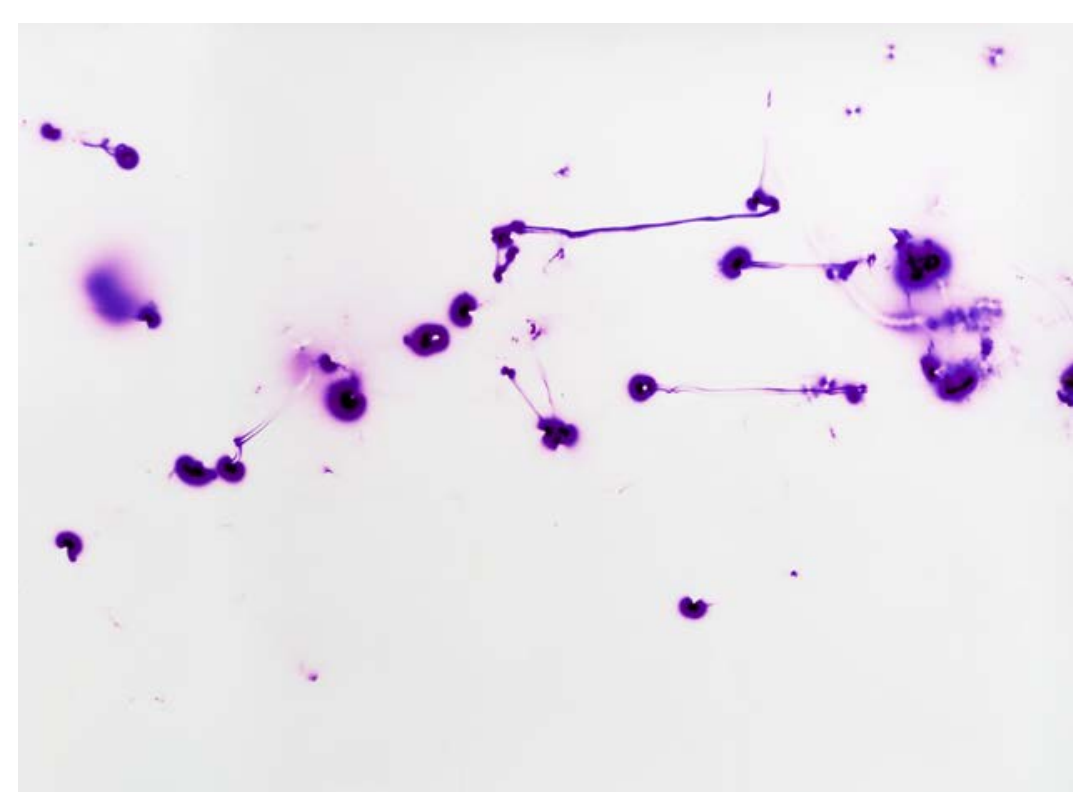

Figura 10 (detalhe)

A segunda experiência relevante foi a elaboração de um fotograma gigante a partir de rolo inteiro de 50 metros comprimento e 1 metro de altura de papel fotográfico. Nessa época tinha 17 anos e ainda não conhecia nem a fotografia generativa alemã e tampouco Làszlo Moholy-Nagy ou Man Ray. Entretanto, acompanhava todo sábado os encontros com o Professor Eduardo Brandão, onde absorvi muitas referências do mundo da arte fotográfica de qualidade. Era quando podia mostrar ao grupo o resultado dessas experimentações fotográficas que fazia na minha cozinha e em meu pequeno laboratório de quintal, o que me motivava a continuar experimentando. 
No estúdio (que deveria ter $3 \times 2$ metros) utilizei várias lanternas coloridas e várias máscaras de cartolina para poder usar como sombra. Preparei muitas traquitanas e diferentes fontes de luz que foram usadas para a elaboração desse fotograma colorido gigante. Assim, no escuro total - pois em um laboratório colorido não há nem a luz avermelhada permitida em um laboratório de fotografia em preto e branco -, estendi aos poucos o papel no chão e, com essas lanternas e filtros, comecei a "desenhar com a luz". Durante dias, na escuridão total, às cegas, trabalhei para tentar atingir a "essência da fotografia" de forma rústica, sem aparelho e de modo temporal e espacial, pois tanto o meu gesto se manifestava como uma dança espacial e temporal quanto o próprio papel, em forma de linha, se estendia pelo tempo e pelo espaço (figura 11).

Talvez, esse tenha sido o aprendizado mais valioso desses experimentos: a fotografia não é necessariamente um corte do tempo e do espaço, mas pode, ao invés, existir de forma contínua, ininterrupta e fluida - pensamento que permanece nos trabalhos atuais.

Segue, com relutância, uma reprodução de fragmentos desse fotograma gigante, pois considero que a fotografia já acontece ali no fotograma, e uma vez que tento sair do programa da fotografia, se torna contraditório usar um aparelho fotográfico para re-fotografá-lo.
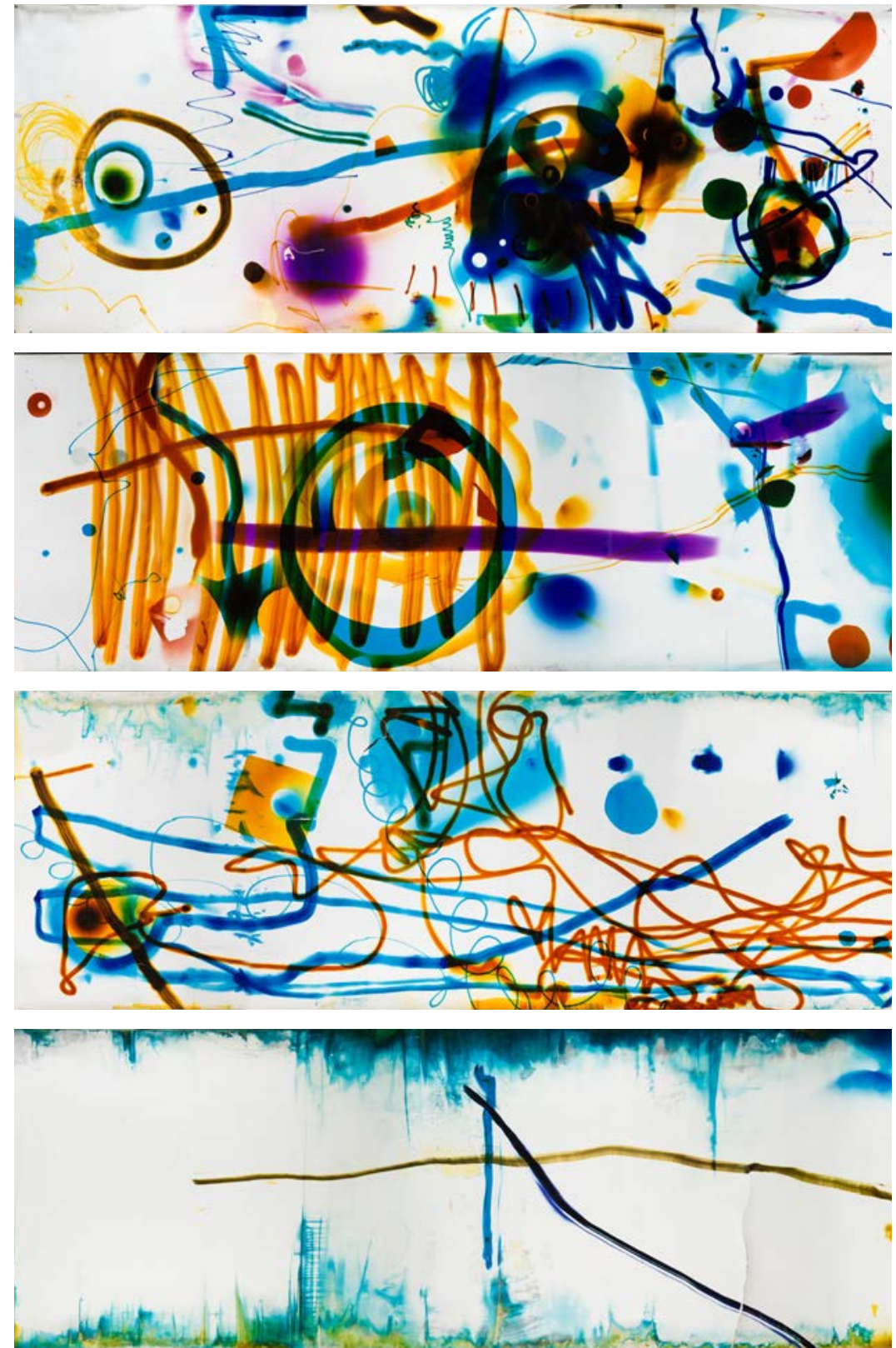

Figura 11 (detalhes) 
A Fotografia SEM A

IMAGEM TÉCNICA

(Análise da produção artística entre 2002 e 2005)

Aos 18 anos ingressei na faculdade de Artes Visuais da Faculdade Armando Álvares Penteado (FAAP) e, logo no primeiro semestre, comecei a introduzir em meus trabalhos um simbolo: o desenho simplificado de um pequeno aparelho fotográfico.

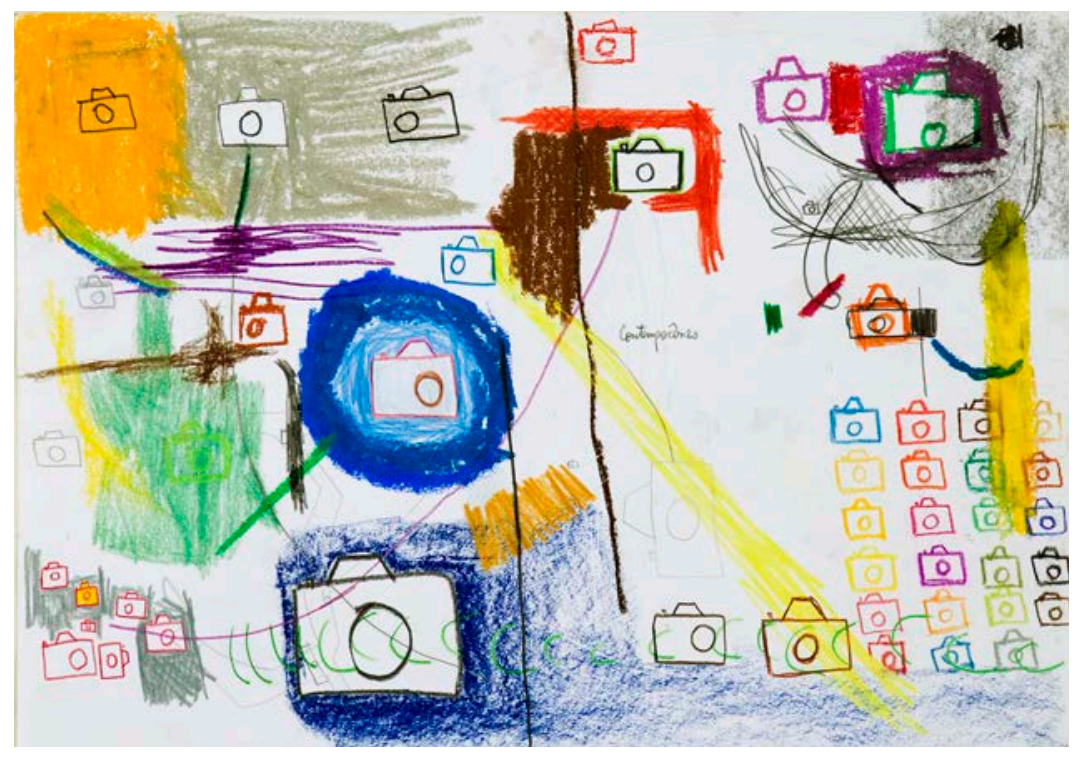

Figura 12
A partir desse momento ocorre uma ruptura formal com todos os aspectos da fotografia, no sentido tradicional do termo. Não há mais qualquer vínculo com a técnica da fotografia: não há mais o uso de matéria fotoquímica, não há mais o uso de um aparelho, não há mais qualquer elemento que ligue formalmente esse desenho ao mecanismo fotográfico. Apenas há na imagem um simbolo fotográfico.

Assim, começo a me afastar do caráter indiciário da fotografia e, simultaneamente, a desenvolver uma outra lógica para ela, baseada, então, em seu caráter simbólico. Qual poderia ser o caráter simbólico da fotografia? Hoje reconheço que precisei de quatro anos para começar a entender essa pergunta e esboçar uma resposta, e vou precisar de muito mais tempo para amadurece-la.

Nesse sentido, considero que nesses trabalhos iniciais tento desenvolver um modo de pensar a fotografia sem a imagem técnica e, ao mesmo tempo, evidenciar seu caráter simbólico. Ou seja, dentro da liberdade da filosofia da fotografia, comecei a desenvolver um modo de pensar a fotografia independente de sua condição indiciária e pragmática, para gerar um sentido para a fotografia inusitado.

Se na arte moderna há, no plano das ideias, uma noção de arte baseada em uma "metalinguagem fotográfica", se na arte contemporânea há uma prática baseada na lógica do índice fotográfico, agora, aos poucos, desenvolvo uma epistemologia baseada na relação simbólica entre a fotografia e o mundo. 
Durante três anos pintei, desenhei, esculpi, gravei e, através de todas as técnicas oferecidas pela faculdade, desenvolvi uma fotografia sem a imagem técnica, sem a contiguidade referencial característica de sua condição indicial e pragmática, apenas de modo simbólico. Ao ver esses desenhos, pinturas e esculturas percebemos que a fotografia está envolvida, mas não sabemos muito bem o porquê.

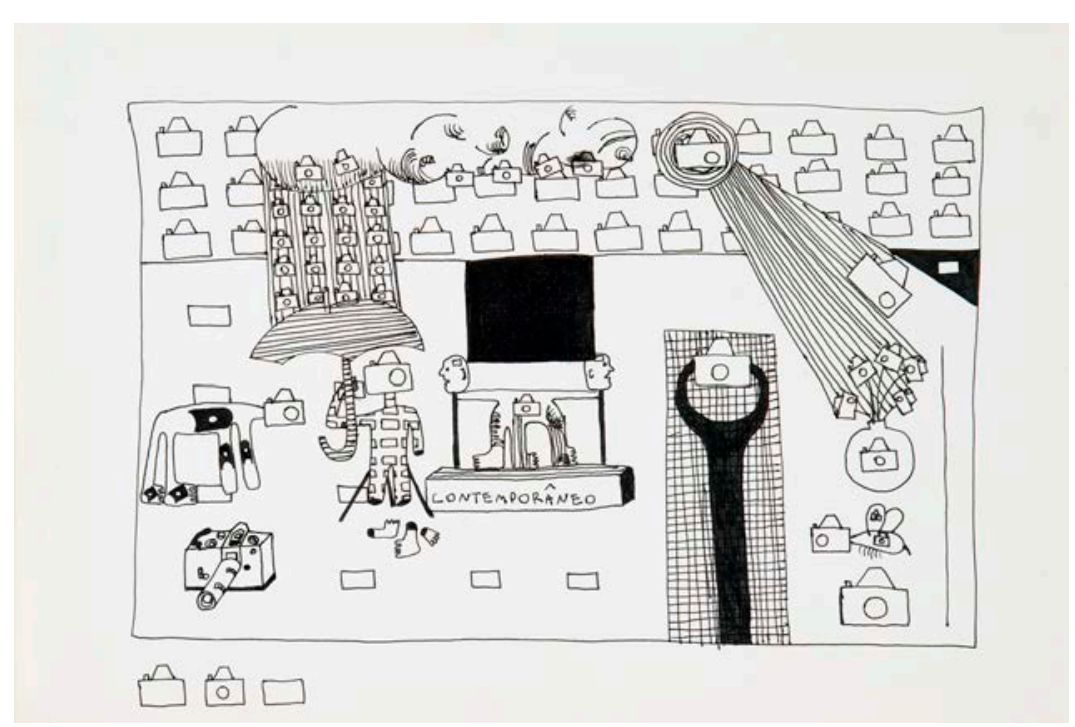

Figura 13

A partir desse momento o trabalho deixa de ser fotografia e passa a ser filosofia da fotografia. Todo significado que pode gerar está na capacidade de ampliar a reflexão sobre a liberdade da fotografia e, assim, de branquear a caixa-preta flusseriana.
Surge uma primeira reflexão: geralmente, quando vemos uma imagem técnica, achamos, mesmo por um breve momento, que vemos o mundo diretamente. Com isso, não deciframos nem a imagem e nem a fotografia, pois achamos que vemos o mundo sem intermediação. Enfim, não percebemos o seu caráter simbólico.
O mundo representado parece ser a causa das imagens técnicas e elas próprias parecem ser o último efeito de complexa cadeia causal que parte do mundo. $\mathrm{O}$ mundo a ser representado reflete raios que vão sendo fixados sobre superfícies sensíveis, graças a processos óticos, químicos e mecânicos, assim surgindo a imagem. Aparentemente, pois, imagem e mundo se encontram no mesmo nível do real: são unidos por cadeia ininterrupta de causa e efeito, de maneira que a imagem parece não ser símbolo e não precisar de deciframento. (FLUSSER, 1983/1985, p. 10)

Diante desses pressupostos observo que, nesses trabalhos iniciais, tenho como objetivo evidenciar radicalmente a presença do caráter simbólico da fotografia, pois inverto completamente o jogo ali estabelecido. Ao invés de a imagem técnica obstruir a percepção do caráter simbólico da fotografia, elaboro imagens nas quais apenas é visível a fotografia como símbolo, excluindo todos os aspectos da imagem técnica.

Desse modo, abre-se um novo terreno para a filosofia da fotografia que passo a cultivar a partir de então. 


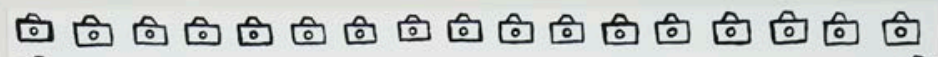

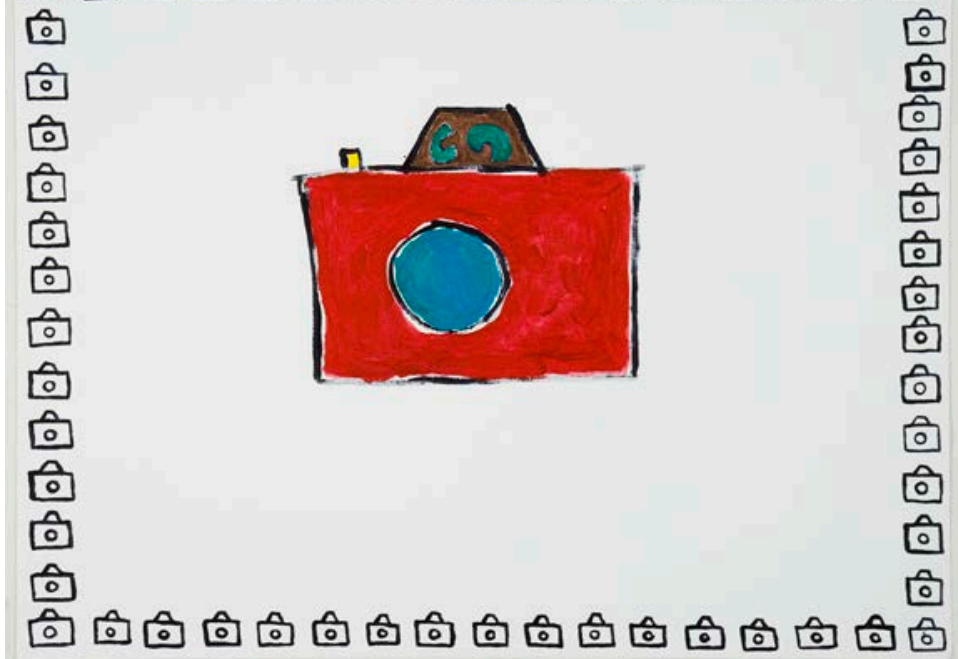

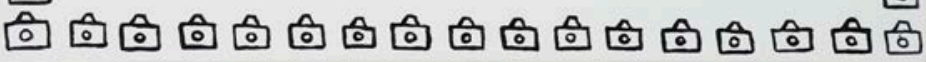

Figura 14

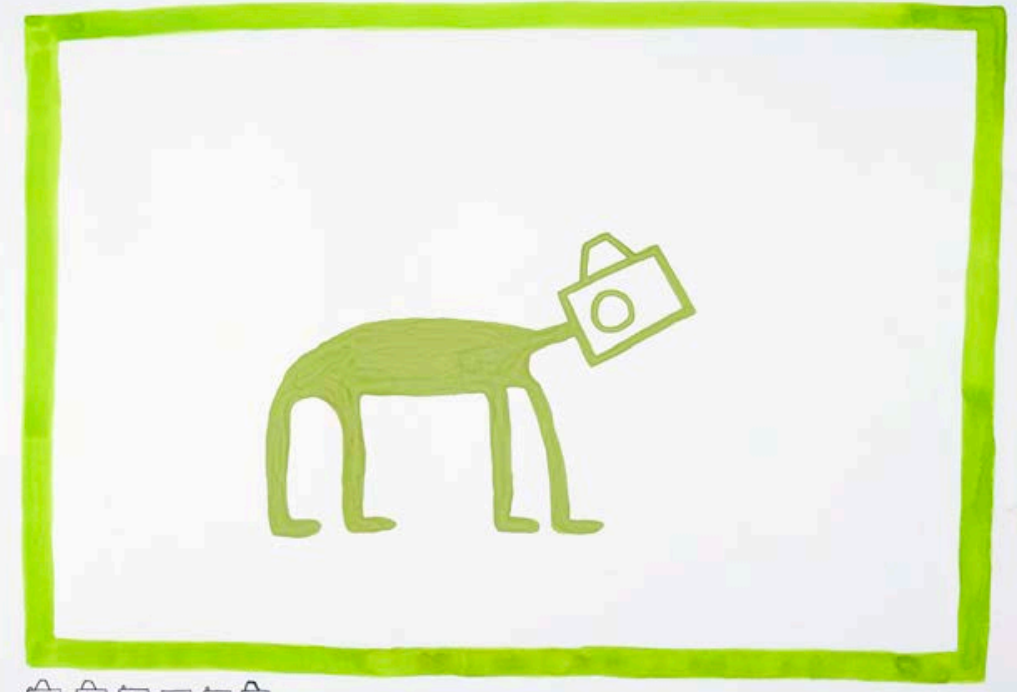

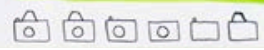

Figura 15

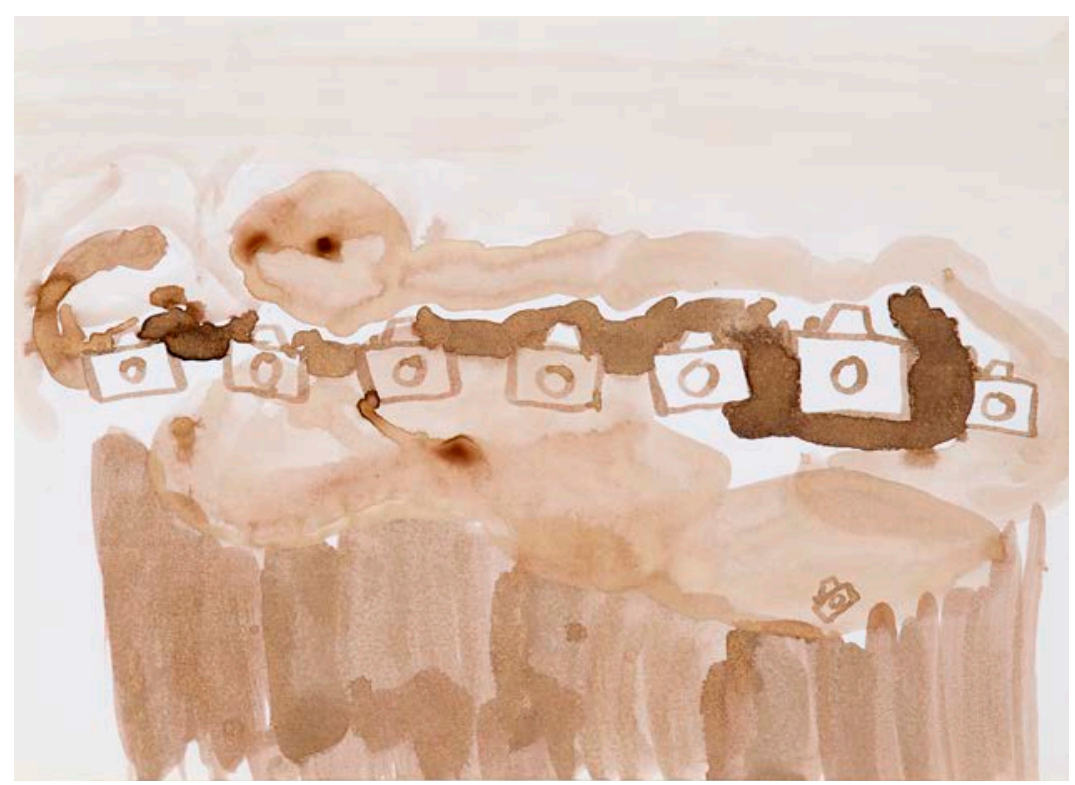

Figura 16

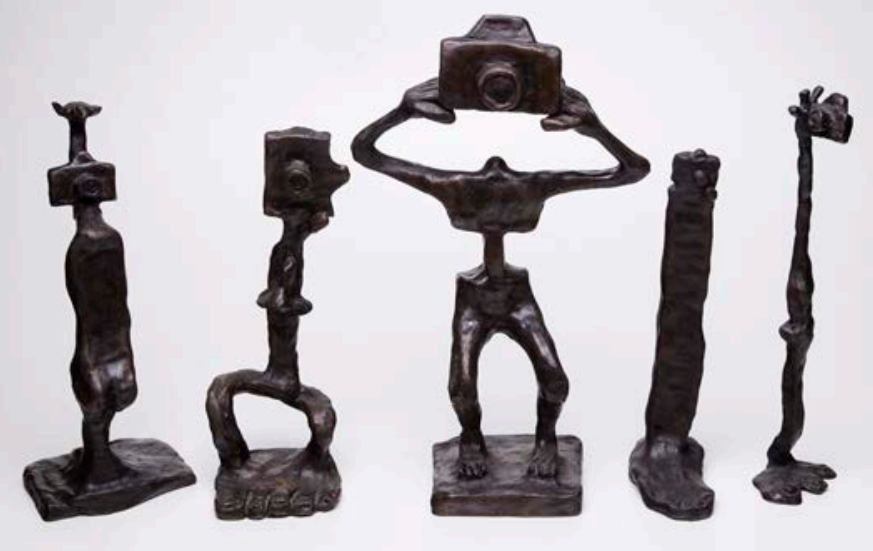

Figura 17 


\section{A Fotografia SEM O}

Ato de Fotografar

(Análise da produção artística de 2006)

No último ano da faculdade, em 2006, comecei a fazer performances com o objetivo de continuar as experimentações sobre o caráter simbólico da fotografia. Se anteriormente busquei uma fotografia sem a imagem técnica, agora vou expandir esse pensamento para o ato de fotografar, pois a fotografia não é apenas uma imagem, mas é uma imagem-ato.

\begin{abstract}
Proponho aqui uma espécie de síntese reflexiva sobre os fundamentos da fotografia, ao mesmo tempo sobre a imagem e sobre $\mathrm{o}$ ato que a definem, e sem que se possa dissociar a primeira do segundo. Porque a fotografia [...] não é apenas uma imagem produzida por um ato, é também, antes de qualquer coisa, um verdadeiro ato icônico 'em si', é consubstancialmente uma imagem-ato. (DUBOIS, 1990/1993, p. 59)
\end{abstract}

Todas as performances foram realizadas em aberturas de exposições do circuito das artes de São Paulo, como na Galeria Vermelho, no Centro Cultural São Paulo, no Museu de Arte Moderna de São Paulo, no Itaú Cultural e na Bienal de São Paulo. É importante ressaltar que nenhuma dessas performances fazia parte oficial da programação das exposições e foram realizadas de forma inde-

pendente.

Nessas performances sempre me rodeava por símbolos fotográficos, como um cajado de alumínio, um ovo dourado, uma roupa de índio, uma máscara fotográfica, etc. Pretendia averiguar se o pensamento sobre a fotografia poderia existir mesmo sem o ato de fotografar, mesmo sem uma atitude pragmática, formando-se apenas através de um gesto simbólico.

Nessas performances, eu apenas "fingia" que fotografava. Eu apenas ficava ali, "fotografando" com meu corpo enfeitado com símbolos fotográficos. Nesses momentos, eu fotografava com a presença de minha vida e não mais com um aparelho técnico. Eu apenas fotografava simbolicamente o que acontecia no entorno.

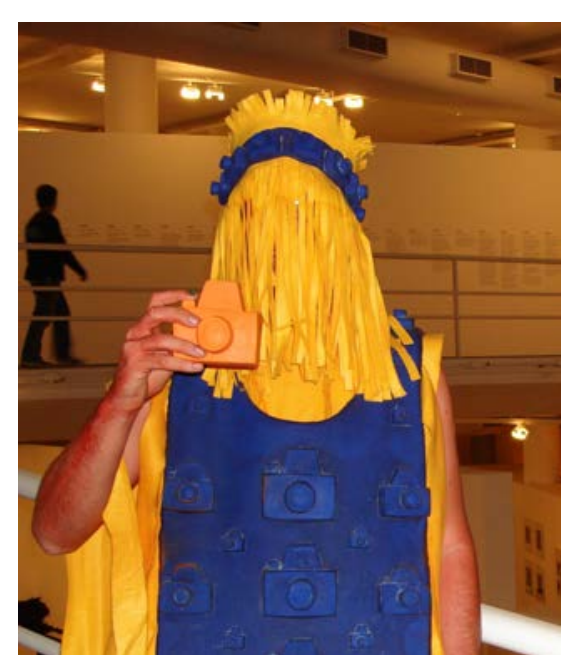

Figura 17: OCA, São Paulo
Em uma ocasião (figura 17), me vesti de Índio Fotográfico. Segurei um chocalho fotográfico na mão, dancei na frente das pessoas fazendo barulho como se fosse um ritual indígena, e entreguei uma foto no qual dizia "manaoca roubou sua alma”, e saia correndo. 
Em outra (figura 18), me vesti de Sêmen Fotográfico. Quando intuía que alguém estava por perto, uma vez que não conseguia ver por detrás da máscara, masturbava o pênis da câmera e disparava um flash, como se a fotografia fosse um gozo de vida.

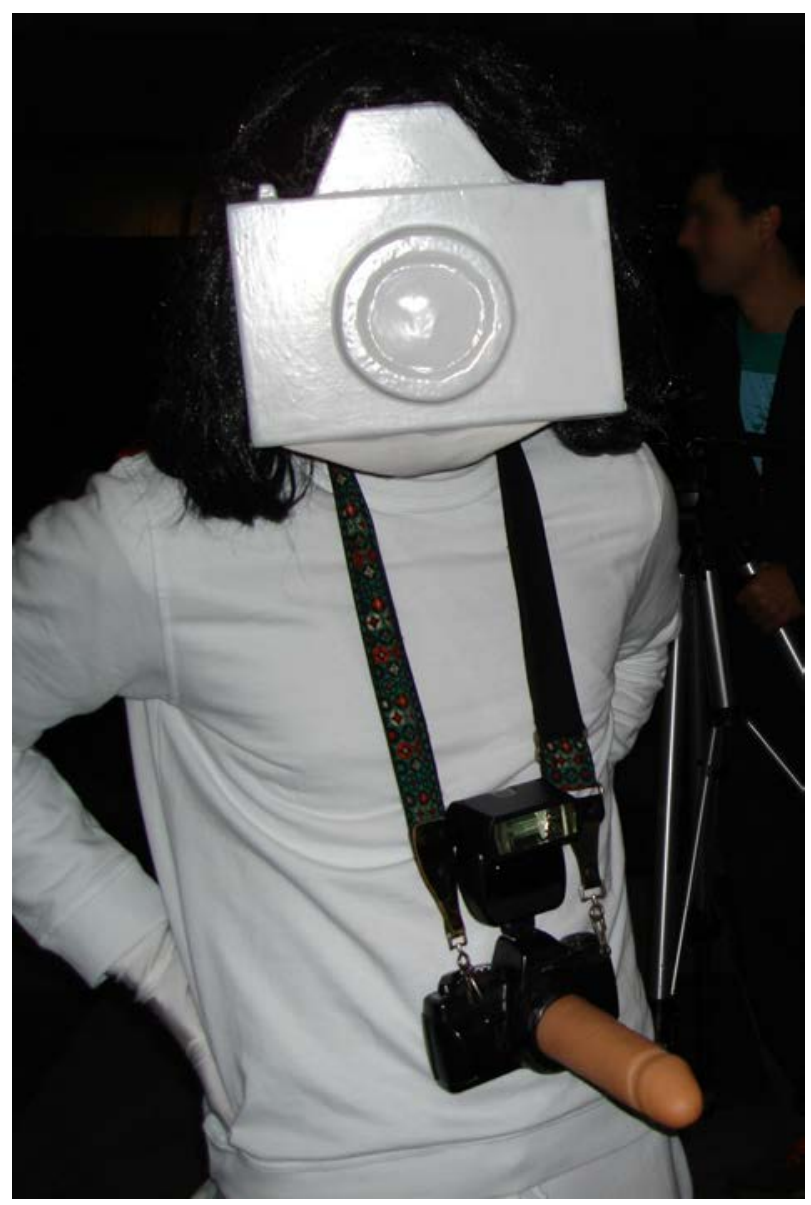

Figura 18: Galeria Vermelho; Bienal de São Paulo
Em outra (figura 19), segurava um ovo fotográfico dourado e pedia para ser fotografado com uma câmera digital pelas pessoas. Assim o fotógrafo me fotografava tecnicamente e eu, em resposta, o fotografava simbolicamente. Ali estabelecia-se uma relação fotográfica nova, no qual o gesto de fotografar era exaltado como o próprio significado daquele momento.

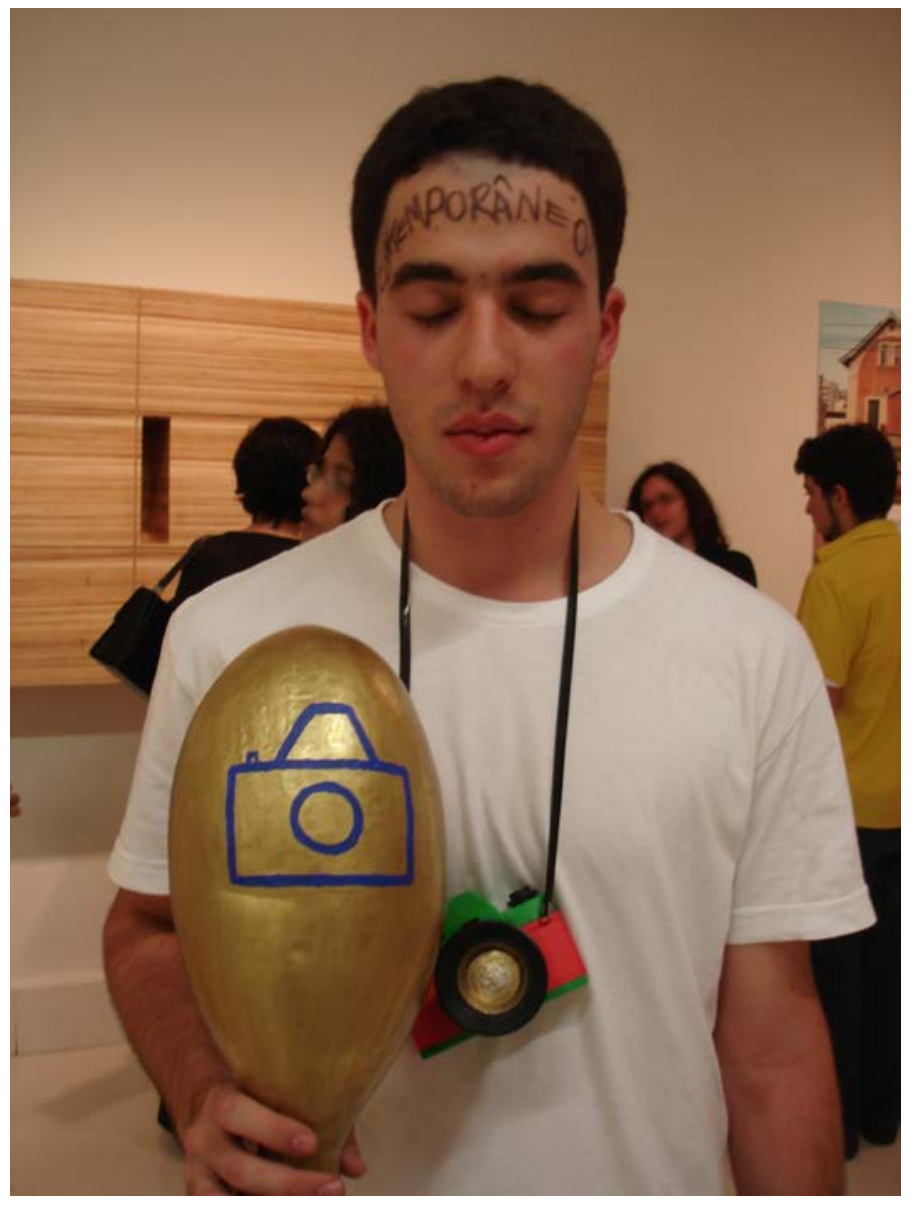

Figura 19: Itau Cultural, São Paulo 
Enfim, busquei nesse conjunto de performances expandir o terreno da filosofia da fotografia ao desenvolver uma reflexão sobre a possibilidade de a fotografia existir mesmo sem o ato de fotografar, se constituindo apenas como um gesto simbólico. Este estará presente em vários trabalhos que realizei desde então.
A FiLOSOFIA DA Fotografia

(Análise da produção artística a partir de 2007)

No dia de minha graduação na faculdade tornei-me oficialmente um jardineiro de arte. Comecei a cultivar profissionalmente a natureza fotográfica da arte e, consequentemente, a filosofia da fotografia.

Nos momentos anteriores, elaborei um modo de pensar a fotografia sem o aparelho fotográfico, sem a imagem técnica e sem o ato de fotografar. De certo modo, desenvolvi uma noção de fotografia que possui uma duração temporal e espacial, cuja dimensão simbólica está presente tanto na imagem técnica quanto no gesto de fotografar. De modo geral, comecei a desenvolver uma alternativa para o caráter indicial e pragmático da fotografia ao cultivar a autonomia de sua dimensão simbólica.

Entretanto, a fotografia não é apenas uma imagem-ato como diz Dubois, mas é um universo. Vivemos em um mundo complexo que utiliza o aparelho fotográfico como modelo. Moramos em um mundo programado onde não temos liberdade. Experienciamos de acordo com aquilo que a fotografia pode nos oferecer. 
Estar no universo fotográfico implica viver, conhecer, valorar e agir em função de fotografias. Isto é: existir em mundo-mosaico. $V i$ venciar passa a ser recombinar constantemente experiências vividas através de fotografias. Conhecer passa a ser elaborar colagens fotográficas para se ter 'visão de mundo'. Valorar passa a ser escolher determinadas fotografias como modelos de comportamento, recusando outras. Agir passa a ser comportar-se de acordo com a escolha. Tal forma de existência passa a ser quanticamente analisável. Toda experiência, todo conhecimento, todo valor, toda ação consiste de bits definíveis. Trata-se de existência robotizada, cuja liberdade de opinião, de escolha e de ação torna-se observável se confrontada com os robôs mais aperfeiçoados. (FLUSSER, 1983/1985, p. 26)

Assim, como branquear a caixa-preta desse universo fotográfico todo? Como transformar sua origem técnica e sua condição pragmática em liberdade e filosofia? Enfim, como elaborar um universo para a fotografia que não esteja sujeito ao programa flusseriano?

De modo geral, a filosofia é uma reflexão acerca da natureza das coisas. Quando se pensa filosoficamente sobre a matemática, se pensa na natureza da matemática. Entretanto, o universo da fotografia se encontra dentro de uma caixa-preta e, por isso, está escondido. Assim, a primeira coisa que um filósofo da fotografia deve fazer é branquear essa caixa-preta para então pensar sobre a natureza que se encontra lá dentro.

Qual será a natureza que se encontra dentro da caixa preta? Ou melhor, essa natureza irá se transformar depois que a caixa pre- ta for branqueada? Flusser, em seus livros, nos mostra o funcionamento determinista e tecnicista do "programa fotografia" que se encontra nessa caixa escura. Nos alerta sobre o fim do pensamento linear característico da história e sobre a instauração de um pensamento circular baseado no eterno retorno característico do programa obscuro da fotografia. Mas, uma vez que esse programa for decifrado e a caixa preta for iluminada, com a liberdade que daí resulta, não se formará uma outra natureza para fotografia? Será que não se formará uma natureza não-programada e não-tecnicista para ela?

Enfim, elaboro com meu trabalho plástico um modo de representar a natureza da fotografia depois que a caixa preta for aberta, no momento em que ela se tornar filosófica. Sob o meu ponto de vista, o programa determinista da fotografia será substituído por uma liberdade simbólica. Se a fotografia não é mais controlada por um programa, ela terá liberdade de ampliar seu domínio para além do plano pragmático e, assim, de criar novas relações simbólicas com o mundo. 


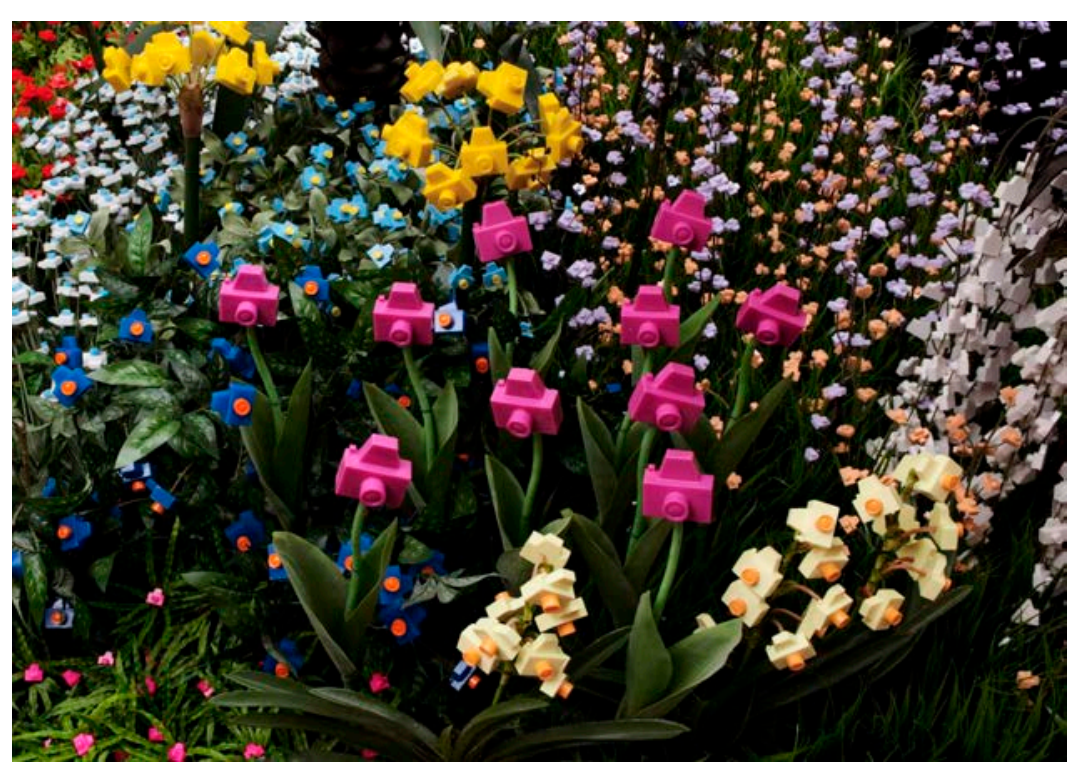

Figura 20

Para tal, criei a ideia de uma natureza que fotografa. Porém, ela não gera imagens, não opera tecnicamente, não programa o comportamento das pessoas, pois apenas fotografa simbolicamente. Ela não possui caixa-preta e fotografa, no campo da filosofia, com liberdade. As pessoas que posam para ela, por sua vez, não precisam sorrir artificialmente, não precisam agir automaticamente, pois não estão sendo controladas pelo aparelho. Essas flores criam a possibilidade de uma relação livre, temporal e simbólica com a fotografia, para além de sua condição tecnicista e determinista.

Nesse sentido, surge a principal função dessas flores que aparentemente são tão ingênuas: representar plasticamente a natureza filosófica da fotografia. Todo o processo de branqueamento da caixa preta e de cultivo de liberdade num mundo programado por aparelhos pode acontecer com a ajuda de uma natureza que fotografa simbolicamente, não-programadamente e não-tecnicamente.

Pretendo, com elas, entre outras coisas, possibilitar a todos - inclusive crianças -, uma reflexão sobre a presença da fotografia em nossas vidas. Com as flores fotográficas (figura 20), pretendo cultivar a filosofia da fotografia de forma ampla e acessível. Se hoje somos funcionários do programa determinista dos aparelhos, amanhã poderemos ganhar liberdade. Se hoje estamos dentro de uma caixa-preta, amanhã poderemos estar dentro de um jardim. Essas flores apenas fotografam simbolicamente e, desse modo, não estão sujeitas ao programa característico dos aparelhos fotográficos.

Além disso, pretendo oferecer com essas flores uma nova possibilidade para o pensamento sobre a fotografia. Hoje em dia, a maioria dos livros sobre o tema elabora reflexões a partir de sua natureza técnica, como o "Ato Fotográfico" de Dubois (1990/1993), "O Fotográfico" de Rosalind Krauss (2002), "A Câmera Clara” de Roland Barthes (1984), entre outros. Minha intenção é, no entanto, propor uma reflexão acerca de sua natureza não-técnica.

O que aconteceria se oferecêssemos à fotografia a liberdade de sua condição indicial e, consequentemente, oferecêssemos autonomia para não exercer mais uma relação necessariamente pragmática com o mundo? E se o modo de pensar fotográfico deixasse de estar ligado à sua origem e à "contiguidade referencial" caracte- 
rístico da técnica para se tornar um pensamento livre, de caráter simbólico, capaz de gerar significados para o campo da fotografia antes inimagináveis? Em outras palavras, e se o pensamento sobre a fotografia se desvinculasse de sua origem determinista e passasse a ser aberto, simbólico e independente?

Mas, o que podemos fazer com toda essa liberdade? Como podemos transformar a fotografia em uma "natureza livre"? Como podemos ampliar o campo de sua filosofia?

Até o momento, dentre muitas possibilidades, elaborei dois caminhos: pensar a fotografia como cultura e pensar a fotografia como escrita. A seguir, desenvolvo um pouco mais a respeito de cada um delas.

\section{Fotografia COMO CUlTuRA}

Dubois descreve três estágios da relação da fotografia com o mundo: a fotografia como espelho do real, a fotografia como transformação do real e a fotografia como traço do real. Proponho $a$ fotografia como cultura.

Podemos pensar, de acordo com a filosofia flusseriana ${ }^{5}$, que a "cultura" pode ser entendida como "natureza" e vice-versa. Hoje em dia, nos afastamos da natureza de tal modo que a cultura tomou seu lugar. Uma árvore transplantada em um parque passa a ser "natureza" ao mesmo tempo em que a Lua dominada pelo homem passa a ser "cultura". Nesse sentido, a cultura passa a ser como uma "segunda natureza" para os homens. Flusser diz:

Destarte, procurou o autor ilustrar [em seu livro] como o homem da atualidade vivencia a cultura: não como algo feito, mas como algo dado, portanto como natureza. O homem atual perdeu o contato com a natureza, no sentido tradicional do termo (ou está perdendo) porque a cultura está assumindo existencialmente o impacto da natureza no significado tradicional do termo (FLUSSER, 2011, p. 162)

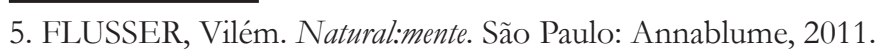


Proponho, em resposta à cultura fotográfica tecnicista atual, seguindo a lógica de meus trabalhos anteriores, o desenvolvimento de uma cultura fotográfica específica, baseada em sua dimensão simbólica. Ao invés de estimular as pessoas a tirarem mais fotografias automaticamente de acordo com um programa determinado, proponho refletir sobre sua própria existência e sobre sua presença em nossas vidas.

Hoje em dia, entretanto, a fotografia já começou a ser percebida em sua dimensão simbólica, autônoma em relação à sua própria condição tecnicista. Com a difusão descontrolada da fotografia digital, cada vez mais se fotografa, mais se percebe que a experiência se tornou fotográfica de modo quase absoluto. Em um show de rock ou em uma viagem, muita gente, ao invés de olhar, fotografa. Hoje em dia, fotografamos tudo e todos, fotografamos o tempo todo. Mas, vemos todas as imagem que fazemos? Ou apenas fotografamos por fotografar? Será que sentimos mais prazer com as imagens geradas ou com a experiência do próprio fotografar? Talvez, fotografamos para "satisfazer o ser" e não apenas para gerar imagens. Fotografamos simbolicamente.

Nesse momento que a prática da fotografia se tornou absurda, pois todos fotografam tudo e não vivenciam nada ${ }^{6}$, as pessoas

6. Neste enfoque poderíamos encontrar um reflexo de uma advertência já feita por Susan Sontag em seu "Ensaios sobre a Fotografia", ao citar A. Feuerbach que "em 1843 ... observava, com relação 'à nossa era' que essa 'prefere a imagem à coisa, a cópia ao original, a representação à realidade, a aparência ao ser"”. SONTAG, Susan. Ensaios sobre a Fotografia. Rio de Janeiro: Ed. Arbor, [1977] 1983. p. 147. começam a perceber que não mais fotografam para gerar imagens, pois na maioria das vezes não reveem as milhares de imagens que fazem. Assim, a autonomia da fotografia em relação à sua própria técnica começa a se revelar de modo "selvagem". Para que se ela se evidencie ainda mais, é necessário cultivá-la.

Pensei: "E se existisse uma festa para comemorar a fotografia?" Hoje em dia, há festas para comemorar a safra de caquis, a imigração italiana, a inauguração de uma exposição de arte. Há festa para tudo e, em todas elas, a fotografia está ali presente, em paralelo, realizando seu papel. Mas, e se existisse uma festa para a fotografia em si? E se existisse uma festa para comemorar a felicidade que a fotografia oferece à nossa vida? Para celebrar o seu papel simbólico de gerar prazer às nossas festas?

Pensando nisso, comecei a fazer festas fotográficas. Convidei os amigos em todas as luas cheias para celebrar e desenvolver a cultura da fotografia. A cada encontro elaborei um tipo novo de comida fotográfica e jogávamos uma brincadeira fotográfica, com o objetivo de criar uma relação pessoal e significativa com a fotografia, apesar de sua técnica e de seu caráter determinista. Realizei esses encontros sempre na lua cheia, pois podemos pensar poeticamente que a lua nos fotografa, como o obturador do universo, que lentamente se abre e se fecha, numa fotografia sem corte, sem interrupção de tempo, que apenas gera relações com o mundo. $\mathrm{Na}$ lua cheia, essa relação fotográfica com o universo está em seu auge, e nós, aqui na Terra, celebramos. 


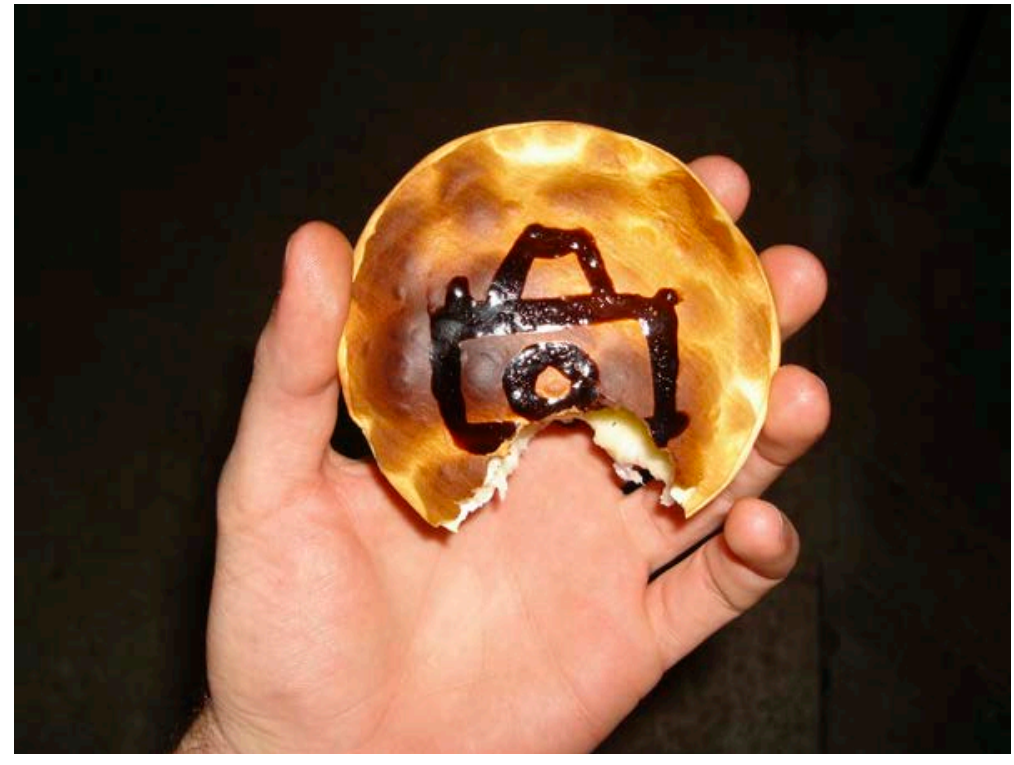

Figura 21: Pastel Fotográfico

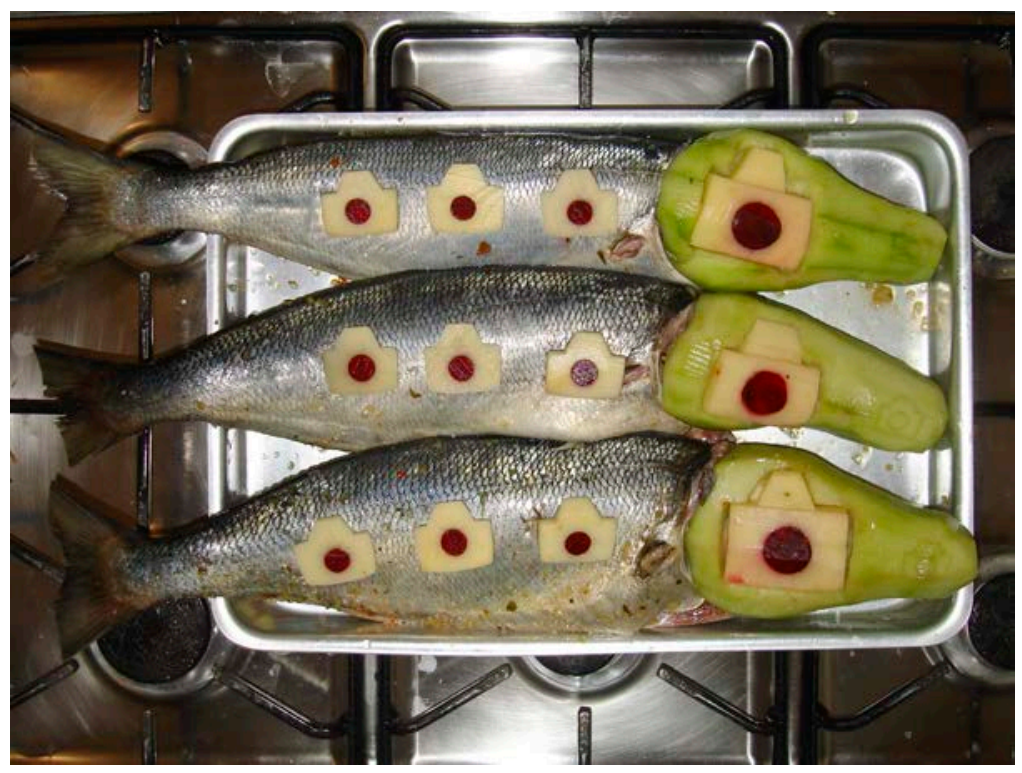

Figura 22: Peixe Assado Fotográfico

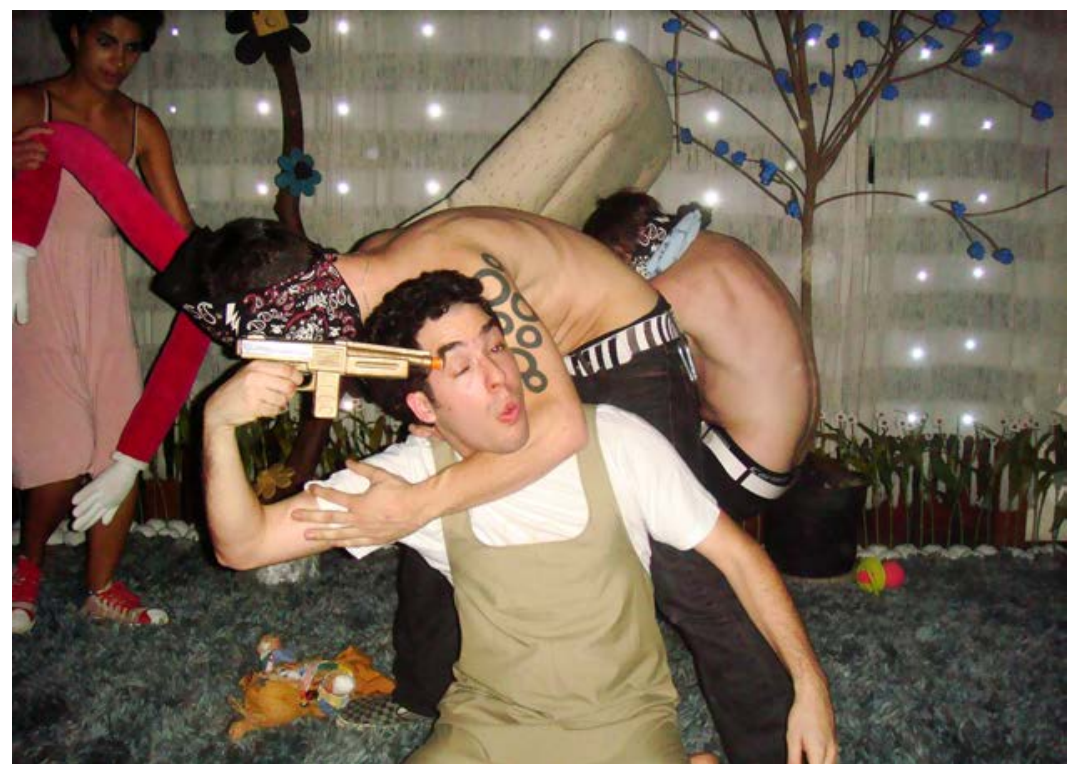

Figura 23: Teatro Fotográfico

As comidas fotográficas (figura 21 e 22) dessas festas eram alimentos que possuíam a forma de uma câmera esculpida simbolicamente, para nos lembrar sobre a presença significativa da fotografia em nossas vidas. Durante a festa, ingerimos esses alimentos para a fotografia fazer parte de nossos corpos e nos oferecer vida.

Os jogos fotográficos, por sua vez, eram brincadeiras lúdicas com o simples objetivo de diversão. A fotografia, nesse sentido, deixa de ser uma ação pragmática, e passa a ser uma ação lúdica, que nos gera alegria. Às vezes, fotografávamos as caretas de cada um e votávamos na mais feia. Fazíamos teatros no escuro e fotografá- 
vamos com flash para ver, apenas através das fotos, as cenas esquisitas e engraçadas que ali se formavam (figura 23). Elaborávamos jogos para brincar e nos divertir.

De modo geral, nessas festas fotográficas, era celebrada a fotografia em si, com o objetivo de nos trazer alegria e possibilitar uma reflexão a respeito de sua importância em nossas vidas. No futuro, espero poder tornar essas festas públicas e, assim, oferecer a todos a possibilidade de vivenciar a fotografia de modo autônomo, cultural e filosófico.

A cultura da fotografia, além das festas, pode tomar muitas outras formas ${ }^{7}$. O que faço aqui é apenas exemplificar sua existência e convidar a todos para elaborar seu próprio meio de celebrar a fotografia em si.

\section{FOTOGRAFIA COMO ESCRITA}

Até o presente momento, apresentei apenas a minha produção visual. Entretanto, paralelamente, desenvolvo uma produção escrita. Já publiquei alguns livros independentes, como "Arte Florescentista" (2008), "Literatura Florescentista - Dois amantes que se amam mas não se mexem" (2008), "Educação Florescentista" (2009) e "Cultura Florescentista" (2010). Considero todos esses livros como nutrientes para o futuro crescimento de um mundo "pós-contemporâneo" que cultivo em conjunto com meu fazer artístico.

Nesse percurso literário, inicialmente no livro "Dois amantes que se amam, mas não se mexem", desenvolvi uma primeira tentativa para se escrever fotograficamente. Ou seja, no campo de liberdade da filosofia da fotografia desenvolvi textos cuja estrutura é fotográfica. No presente texto, aprimoro essa ideia.

Minha hipótese é: podemos utilizar a estrutura temporal e espacial da fotografia para desenvolver um modo específico de escrever e, assim, desenvolver uma estrutura fotográfica para o pensamento.
7. O meu trabalho escrito de graduação, no bacharelado da FAAP (Faculdade Armando Alvares Penteado), se chama "Cultura Fotográfica", onde se encontram mais tentativas de desenvolver essa cultura específica. Pode ser consultado na biblioteca da FAAP ou na biblioteca do Museu de Arte Moderna de São Paulo. 
Dessa forma, será possível "pensar fotograficamente" sobre qualquer assunto, inclusive sobre a vida, arte e filosofia, desvinculando-se completamente do programa determinista da fotografia e de sua condição indicial. Essa estrutura fotográfica de pensamento, sob meu ponto de vista, é a concretização da filosofia da fotografia e de sua potência simbólica, pois se encontra unificada com a própria estrutura da linguagem e, assim, com o modo de pensar humano.

Surgem perguntas obrigatórias: qual é a estrutura da fotografia? Por que esta estrutura fotográfica é diferente dos outros tipos de estruturas? Como podemos traduzir isso em escrita? O pensamento de Flussser ${ }^{5}$ diz:

Fotografias, filmes, imagens de TV, de vídeo e dos terminais de computador assumem o papel de portadores de informação outrora desempenhado por textos lineares. Não mais vivenciamos, conhecemos e valorizamos o mundo graças a linhas escritas, mas agora graças a superfícies imaginadas. Como a estrutura da mediação influi sobre a mensagem, há mutação na nossa vivencia, nosso conhecimento e nossos valores. $\mathrm{O}$ mundo não se apresenta mais enquanto linha, processo, acontecimento, mas enquanto plano, cena, contexto - como era no caso da pré-história e como ainda é o caso para os iletrados. [...] não se trata de retorno a situação pré-alfabética, mas de avanço rumo a situação nova, pós-histórica, sucessora da história e da escrita. (FLUSSER, 1983, p.15)

5. FLUSSER, Vilém. O Universo das Imagens Técnicas: Elogio da superficialidade. São Paulo: Annablume, 2008.
Neste pequeno trecho, de modo denso, está resumido praticamente todo o pensamento de Flusser a respeito da mudança estrutural que as imagens técnicas (principalmente a fotografia) causaram no mundo. Em primeiro lugar, deve ficar claro algo muito importante do pensamento flusseriano: a invenção da fotografia é um evento tão importante para a humanidade quando a invenção da escrita $^{6}$. Nesse sentido, a humanidade pode ser dividida em três períodos: antes da invenção da escrita, na pré-história, no qual os homens pensavam magicamente através das imagens. Depois da invenção da escrita, a partir do qual os homens começaram a pensar linearmente e, por isso, inventaram a história. E, finalmente, com a invenção fotografia, a partir do qual a estrutura linear dos textos é substituída pela estrutura circular da imagem (plano, cena e contexto), e consequentemente, a consciência histórica deixa de existir e é substituída pela pós-história.

É justamente a estrutura de pensamento da pós-história que utiliza a fotografia como modelo que nos interessa. De acordo com o trecho acima, o modo de vivenciar, de valorar e de conhecer o mundo deixou de estar baseado em uma estrutura de linha, processo e acontecimento - característico dos textos e da história -, e passou a se basear em uma estrutura do plano, da cena e do contexto característico da fotografia e da pós-história. Ou seja, paramos de relacionar "o que aconteceu", "o que acontece", e

6. FLUSSER, Vilém. A Filosofia da Caixa Preta: Estudos para uma Futura Filosofia da Fotografia. São Paulo: Hucitec, [1983] 1985. Capítulo 2. p. 10. 
“o que vai acontecer" característico de um pensamento linear, de processo e de acontecimento, para uma outra estrutura na qual os tempos verbais devem apenas suscitar cenas e não processos, devem apenas criar contextos e não história, devem deixar a estrutura da linha para virar planos. O desafio da escrita fotográfica é justamente esse.

O pensamento flusseriano também nos oferece uma descrição precisa sobre a forma espacial da estrutura de pensamento característico da pós-história. Para tal, compara a imagem tradicional (como a pintura), com a imagem técnica (como a fotografia):

\begin{abstract}
As novas imagens [técnicas] não ocupam o mesmo nível ontológico das imagens tradicionais, porque são fenômenos sem paralelo no passado. As imagens tradicionais são superfícies abstraídas de volumes, enquanto as imagens técnicas são superfícies construídas por pontos. De maneira que, ao recorrermos a tais imagens, não estamos retornando da unidimencionalidade para a bidimencionalidade, mas nos precipitando da unidimencionalidade para o abismo da zero-dimencionalidade. Não se trata de volta do processo para a cena, mas sim de queda do processo rumo ao vácuo dos quanta. (FLUSSER, 2008, p. 15)
\end{abstract}

Esse trecho merece uma explicação. De modo geral, o pensamento de Flusser apresenta a diferença entre as imagens tradicionais e as imagens técnicas. O que nos importa no momento é o seguinte: a imagem tradicional, para ser realizada, utiliza duas dimensões do

7. FLUSSER, Vilém. O Universo das Imagens Técnicas: Elogio da superficialidade. São Paulo: Annablume, 2008. tempo/espaço, ou seja, é construída em um plano, que possui uma horizontal e uma vertical, em um espaço bidimensional. A imagem tradicional, nesse sentido, traduz os volumes de três dimensões (como uma árvore, uma pessoa ou qualquer objeto do mundo) em imagens planas de duas dimensões. Já a imagem técnica, apesar de aparentemente ser bidimensional como as imagens tradicionais, ao invés, são zero-dimensionais, pois não foram construídas na transformação do volume em plano, mas pelo contrário, foram formadas a partir de pontos, de grãos, de pixels. Ou seja, as imagens técnicas não são provenientes de um mundo de três dimensões, não são transformações do mundo que está à nossa frente em planos, mas surgem do nada, como um aglomerado de pontos em um espaço sem-altura, sem-largura, sem-profundidade, quântico, zero-dimensional.

Nesse contexto, segundo Flusser, as imagens técnicas não representam o mundo lá fora, assim como as imagens tradicionais. Mas, ao invés, "imaginam textos que concebem imagens que imaginam o mundo" (FLUSSER, 1983/1985, p. 10). Ou seja, são formadas por conceitos que formam imagens de mundo. Mesmo sendo as imagens técnicas zero-dimensionais, elas são constituídas em sua superfície por textos imaginativos. A escrita fotográfica é justamente a formalização desses textos imaginativos que se encontram no interior da imagem fotográfica e na estrutura de viver, valorar e conhecer pós-histórico.

O que já sabemos sobre a escrita fotográfica? 
A escrita fotográfica utiliza uma estrutura temporal não-linear, mas circular, cuja noção de processo e acontecimento foi substituída por uma noção de cena e contexto. A escrita fotográfica também utiliza uma estrutura espacial zero-dimensional, cuja matéria são pontos e não linhas, planos ou volumes. Enfim, a escrita fotográfica resulta em textos imaginativos.

Como podemos, no domínio das regras da língua portuguesa, escrever fotograficamente seguindo as características citadas acima? Vamos desenvolver a forma dessa escrita fotográfica aos poucos.

$\mathrm{Na}$ língua portuguesa (assim como em muitas línguas) a estrutura temporal é concomitante aos tempos verbais. De modo geral, a estrutura resultante com o uso de verbos é linear, pois os tempos verbais foram elaborados para causar uma noção de passado, presente e futuro. "Eu escrevia este texto, mas a luz acabou. Quem sabe amanhã poderei voltar ao meu trabalho". Porém, se não queremos utilizar essa estrutura de história, não podemos utilizar esses tempos verbais que, em linha, criam noções de processo e acontecimento. Então, como podemos fazer para escrever em uma estrutura de cena e contexto da pós-história?

O único modo verbal que não indica a passagem linear do tempo é o modo infinitivo. De acordo com o Wikipédias, o verbo no infinitivo se apresenta "naturalmente", sem qualquer conjugação; dá a

8. Disponível em: http://pt.wikipedia.org/wiki/Infinitivo. Acesso em: 20 de junho de 2013. ideia de uma ação ou estado sem vinculá-la a um tempo, modo ou pessoa específica. Ou seja, o verbo infinitivo é exatamente o que procuramos: por não estar vinculado a um tempo, não gera nem processos e nem acontecimentos, mas planos, cenas e contextos. O verbo infinitivo é o verbo da pós-história.

Já possuímos a estrutura temporal da escrita fotográfica. Agora, como podemos desenvolver sua estrutura espacial? Como podemos criar uma situação de zero-dimensionalidade, como podemos criar um texto baseado em uma estrutura de pontos, grãos ou pixels?

Para eliminar toda estrutura dimensional do texto, precisamos eliminar, em primeiro lugar, todo tipo de pontuação, pois é pela pontuação que as partes individuais dos textos se relacionam para criar linhas, planos e volumes. A vírgula indica uma pausa. Um ponto final indica que a frase acabou. Os dois pontos indicam uma citação. Dependendo do sinal de pontuação, o texto toma uma direção ou outra. Ou seja, cada sinal de pontuação indica a "geometria" e o ritmo do texto, como se cada sinal de pontuação fosse um vértice em um polígono multifacetado que se constrói durante a leitura. Assim, se queremos construir um texto zero-dimensional, precisamos descartar todo tipo de pontuação.

O que restou para o texto? Como podemos escrever um texto sem tempos verbais e sem pontuação? Como podemos escrever apenas com verbos infinitivos e palavras soltas no espaço? Não podemos esquecer a terceira característica da escrita fotográfica: 
ela resulta em um texto imaginativo. Isso pode nos ajudar a organizar as palavras soltas e os verbos infinitivos na folha de papel.

Se a escrita fotográfica é um texto imaginativo, ela deve gerar necessariamente imagens. Por isso, as palavras soltas (sem pontuação) no papel podem se agrupar de acordo com a imagem que o escritor quer fazer. Porém, esse texto imaginativo não pode ter nenhum tipo de dimensão, pois deve ser zero-dimensional. Então, ao mesmo tempo em que juntamos palavras para gerar imagens, não podemos agrupar essas imagens com o verbo infinitivo, pois a junção do "tempo" do verbo infinitivo com o "espaço" das palavras em conjunto resultaria na criação de uma dimensão. Portanto, na escrita fotográfica, podemos agrupar palavras, mas não podemos reagrupar essas palavras com os verbos. Assim, os verbos infinitivos devem estar isolados.

Estas são minhas deliberações sobre a estrutura da escrita fotográfica. A partir desse momento, as configurações que o texto ganhar são opções estilísticas de cada autor.

Para finalizar este texto, apresento a minha versão de como escrever e pensar fotograficamente, de como combinar as ideias utilizando uma estrutura fotográfica, pós-histórica, baseada em um tempo não-linear, mas circular, cuja noção de processo e acontecimento foi substituída por uma noção de cena e contexto, e que, ao mesmo tempo, utiliza uma estrutura espacial zero-dimensional, cuja matéria são pontos, e não linhas, planos ou volumes, em um texto imaginativo.
$\mathrm{Na}$ minha versão da escrita fotográfica organizo os conjuntos de palavras e os verbos infinitivos como se estivessem em queda livre no papel, em direção ao zero-dimensional, num lugar sem espaço e num espaço sem tempo, no qual cada verbo é um ponto e cada conjunto de palavras é outro, num eterno gotejar do pensamento.

fotografar

sem mais a técnica determinista dos aparelhos fotográficos daquela vida controlada

comemorar

a liberdade da fotografia do lado de fora da caixa preta flusseriana com uma enorme festa

dançar

fotograficamente o tempo todo com câmeras de brinquedo junto dos amigos e da alegria

comer 
bolos doces pastéis e tortas sob a lua cheia fotográfica em sintonia com o universo

festejar

a autonomia da fotografia para além de sua origem técnica como uma reflexão filosófica

pensar

sobre a presença da fotografia na nossa vida imagética e nas nossas próprias emoções

sentir

essa presença fotográfica nos momentos mais íntimos e significativos do universo

transformar

todo ato pragmático em fotografias contínuas e sem relação direta com o mundo fotografar

com os dedos no bolso da calça com os olhos completamente fechados de modo simbólico e livre

\section{sorrir}




\section{CONCLUSÃo}

Durante o meu percurso de produção visual busquei, inicialmente, me desvincular do programa tecnicista da fotografia. Primeiro fotografei sem o aparelho fotográfico, em seguida sem a imagem técnica, depois sem o ato de fotografar. Nesse processo, cultivei reflexões sobre a filosofia da fotografia, pois ofereci liberdade à fotografia em geral.

Ao mesmo tempo, tentei me desvincular da lógica indiciária ali presente, com o objetivo de desenvolver um outro modo de pensar a fotografia, baseado, em seu caráter simbólico. Para tanto, elaborei, sob meu ponto de vista, um modo de representar plasticamente da fotografia: uma natureza cujas flores fotografam simbolicamente, constantemente e com liberdade.

A partir de então comecei a desenvolver uma cultura fotográfica específica, cuja principal função é refletir e celebrar a presença da fotografia em nossas vidas.

Enfim, utilizando toda liberdade proveniente da dimensão simbólica da fotografia proponho a "escrita fotográfica". Ou seja, proponho uma estrutura específica para escrever e pensar fotograficamente sobre qualquer assunto.
Assim, nesse conjunto de possibilidades, concluo que a grande preocupação de meu trabalho como jardineiro de arte é ampliar o campo de liberdade da filosofia da fotografia e, consequentemente, da própria natureza da arte.

De acordo com Dubois, com a invenção da fotografia, "a arte virá a partir de então extrair, das condições epistêmicas da fotografia, possibilidades singulares de renovação de seus processos criativos e de suas apostas estéticas principais" (DUBOIS, 1990/1993, p. 258). Entretanto, utilizam uma epistemologia da fotografia baseada em suas qualidades indiciais. Tento, diferentemente, no conjunto de meu trabalho, desenvolver uma epistemologia da fotografia baseada em seu caráter simbólico. Nesse sentido, me esforço para elaborar uma estrutura de pensamento não-moderna e não-contemporânea para a arte.

A partir da publicação deste texto deixo de produzir conscientemente uma arte cujo objetivo é inscrever no produto artístico o processo do qual é resultado, ou uma arte que necessite de uma conexão pragmática com uma situação determinada para ter sentido. Ou seja, a partir de agora passo a cultivar uma arte cuja estrutura básica de significação não esteja ligada à metalinguagem ou à lógica do índice, mas sim uma arte cuja natureza fotográfica é simbólica, cultural e livre. 
VIVÁRIO IMAGINÁRIO*

* Esse vivário se fundamenta no museu imaginário de Malraux (1965/2000). Por isso, as imagens aqui apresentadas não indicam o tamanho, o ano de produção ou a técnica utilizada dos trabalhos originais. Os trabalhos foram deslocados para um ambiente imaginário. 

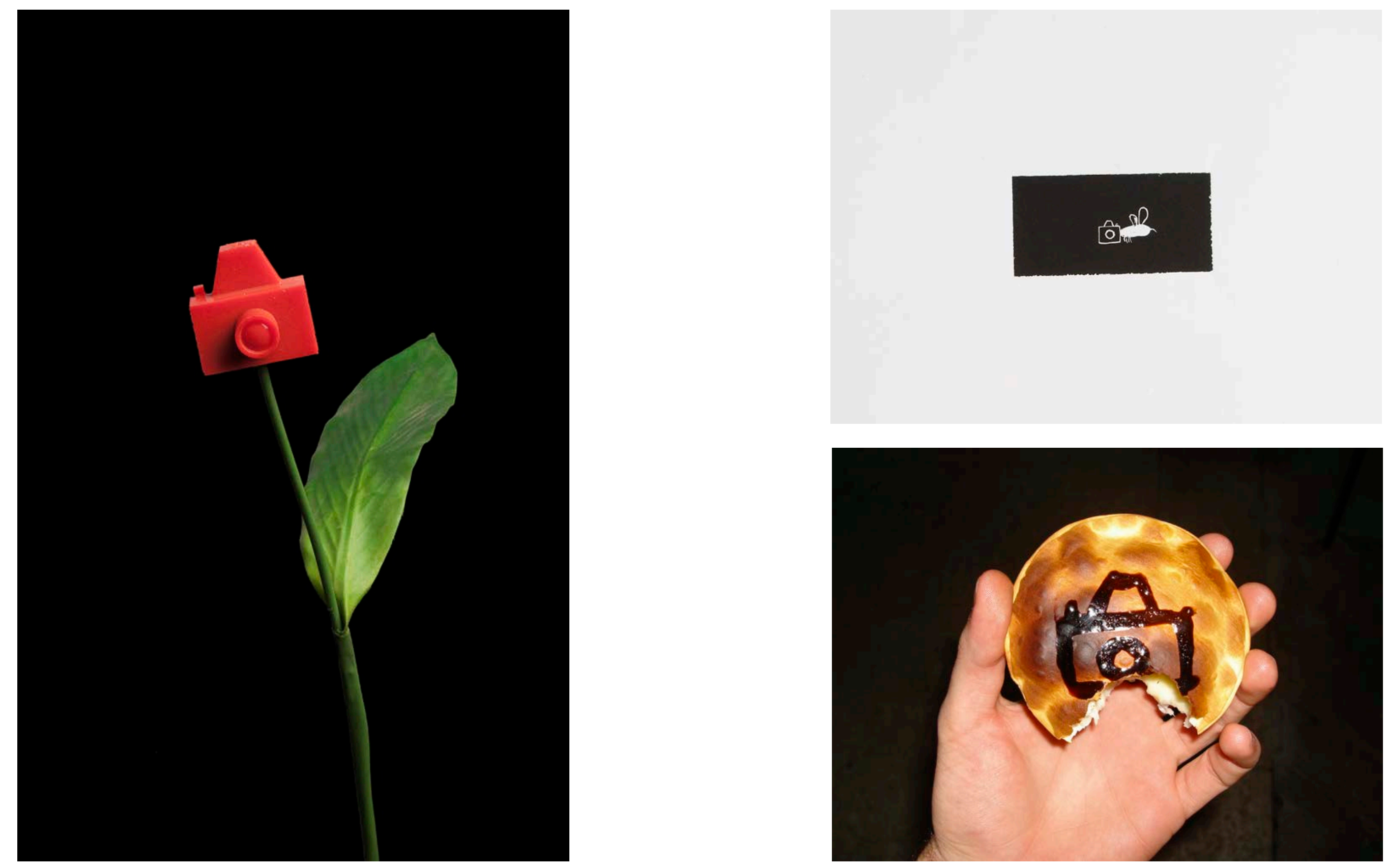


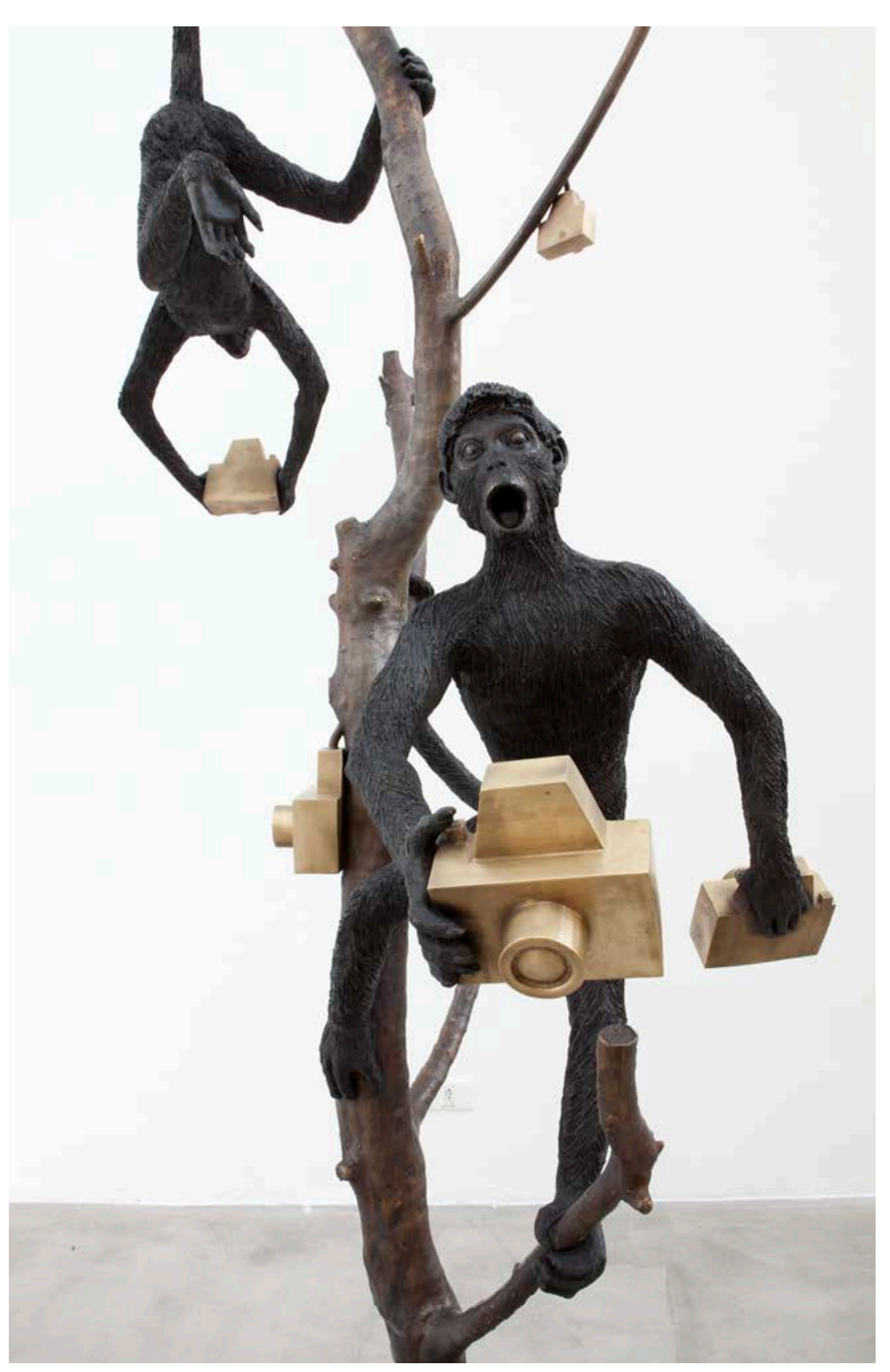

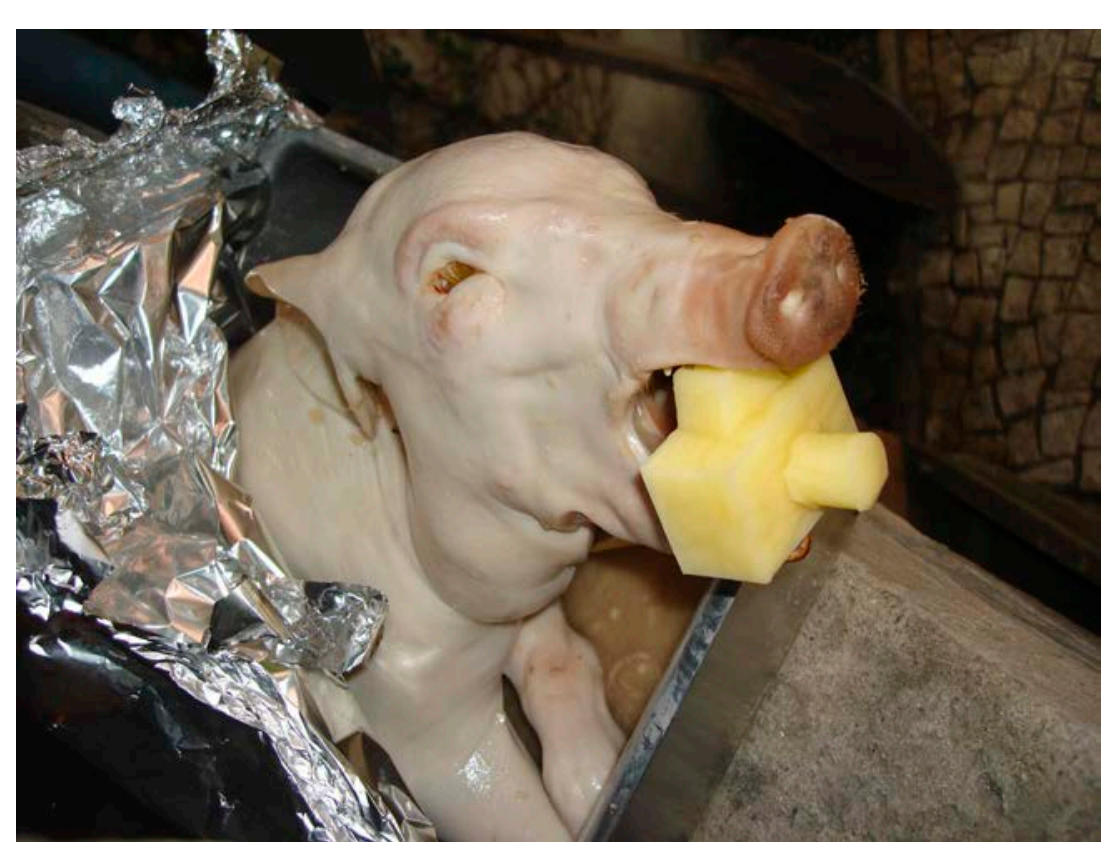

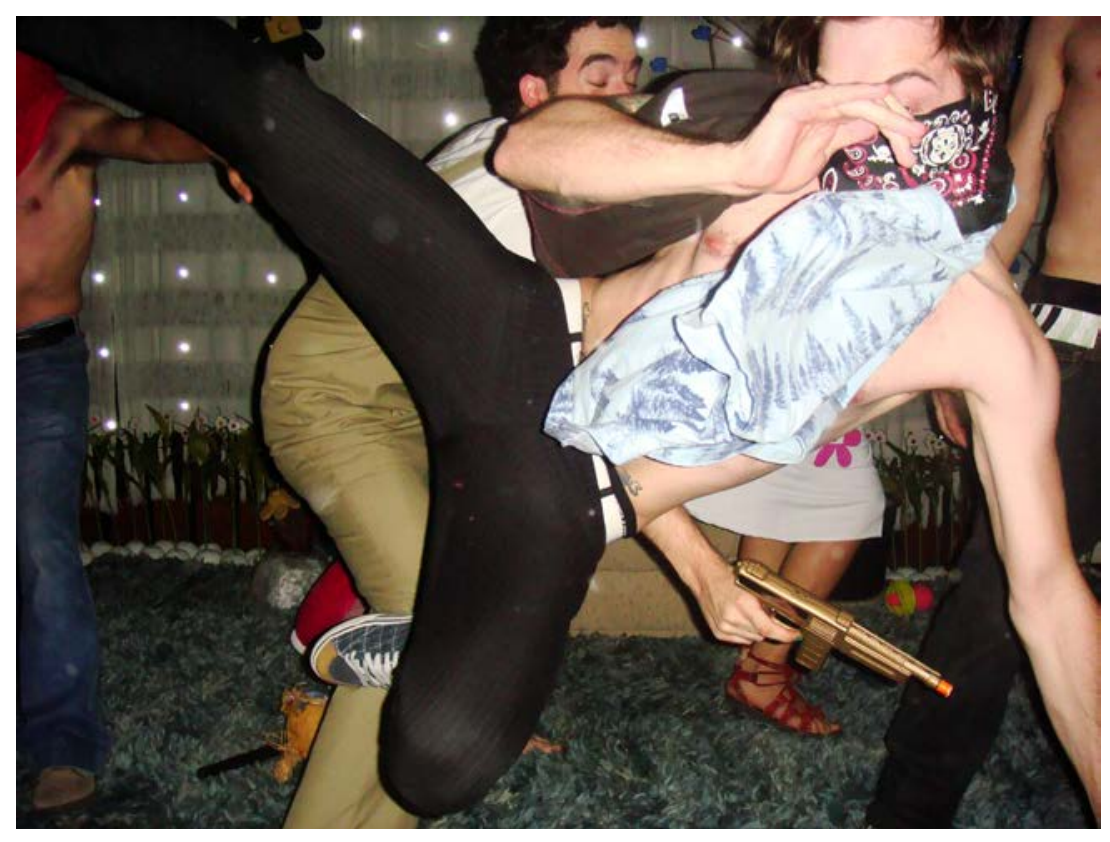

133 
응
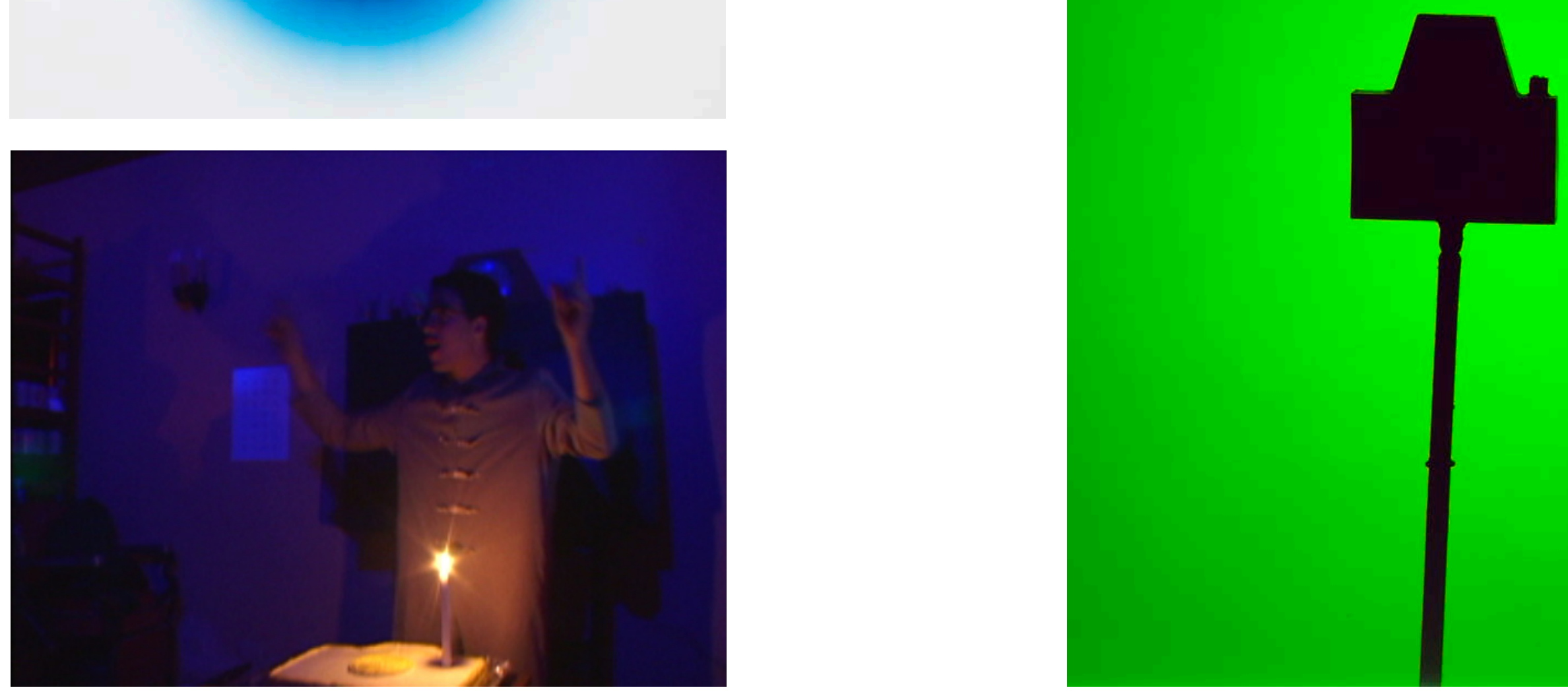

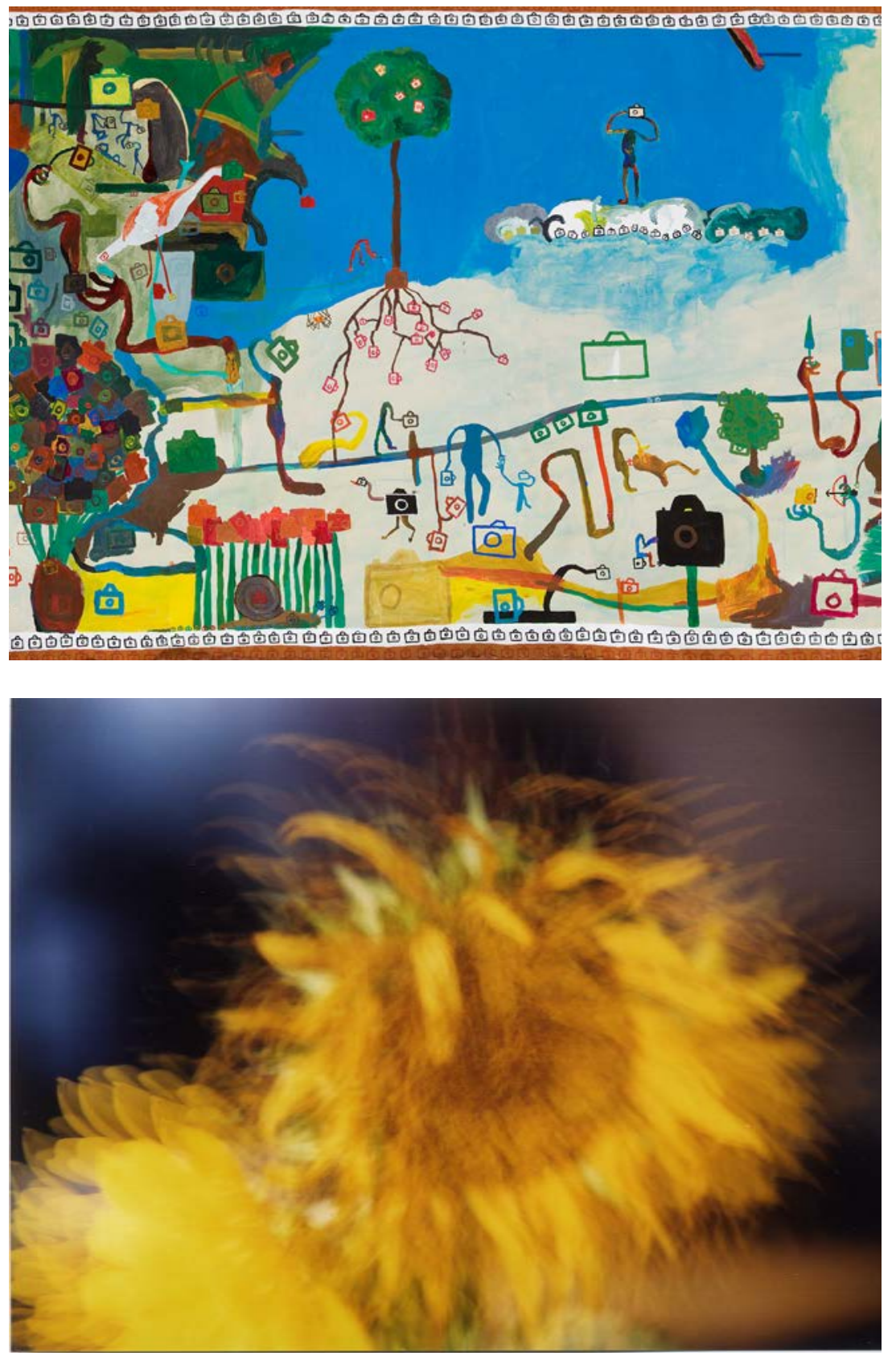
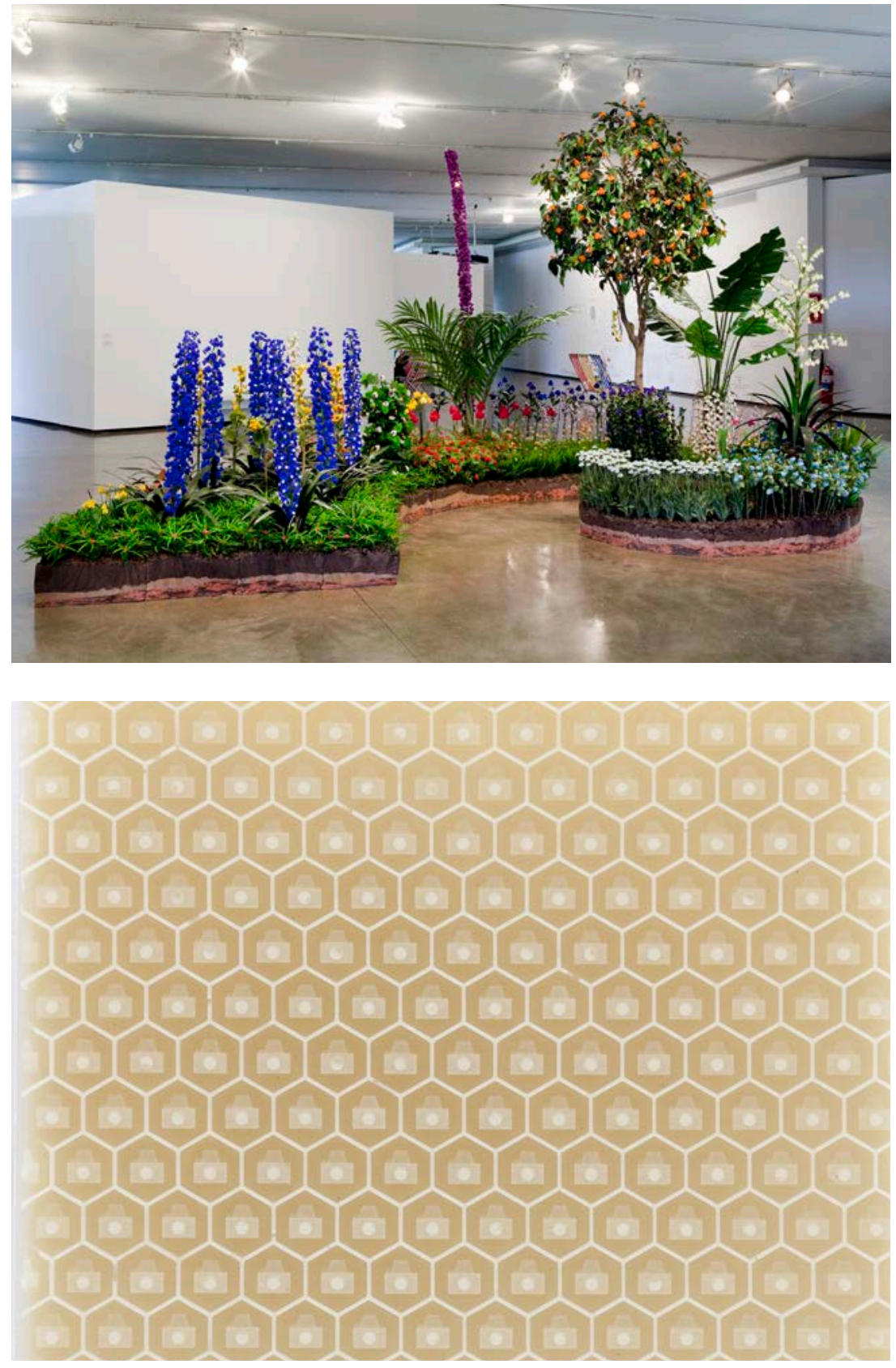
-

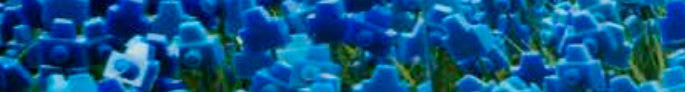

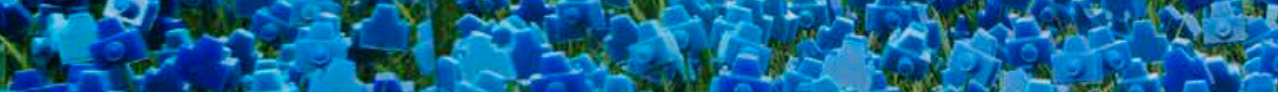

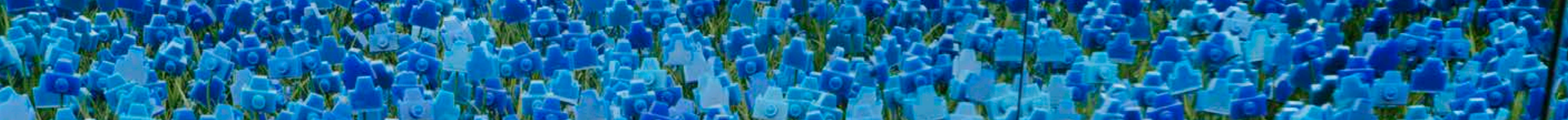

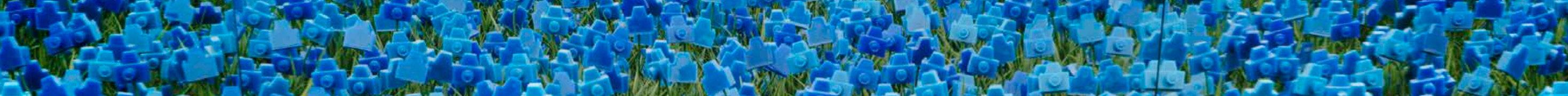

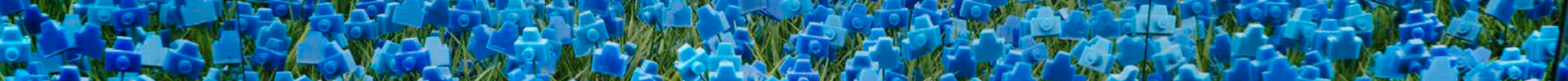
1.5.

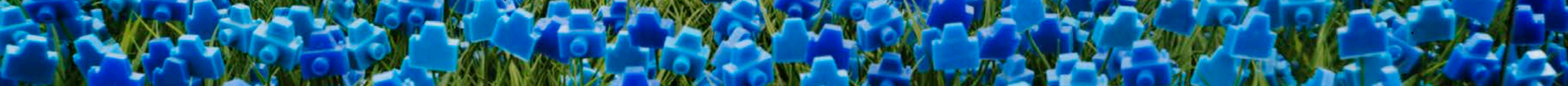
4. (W. S. 4 10 8
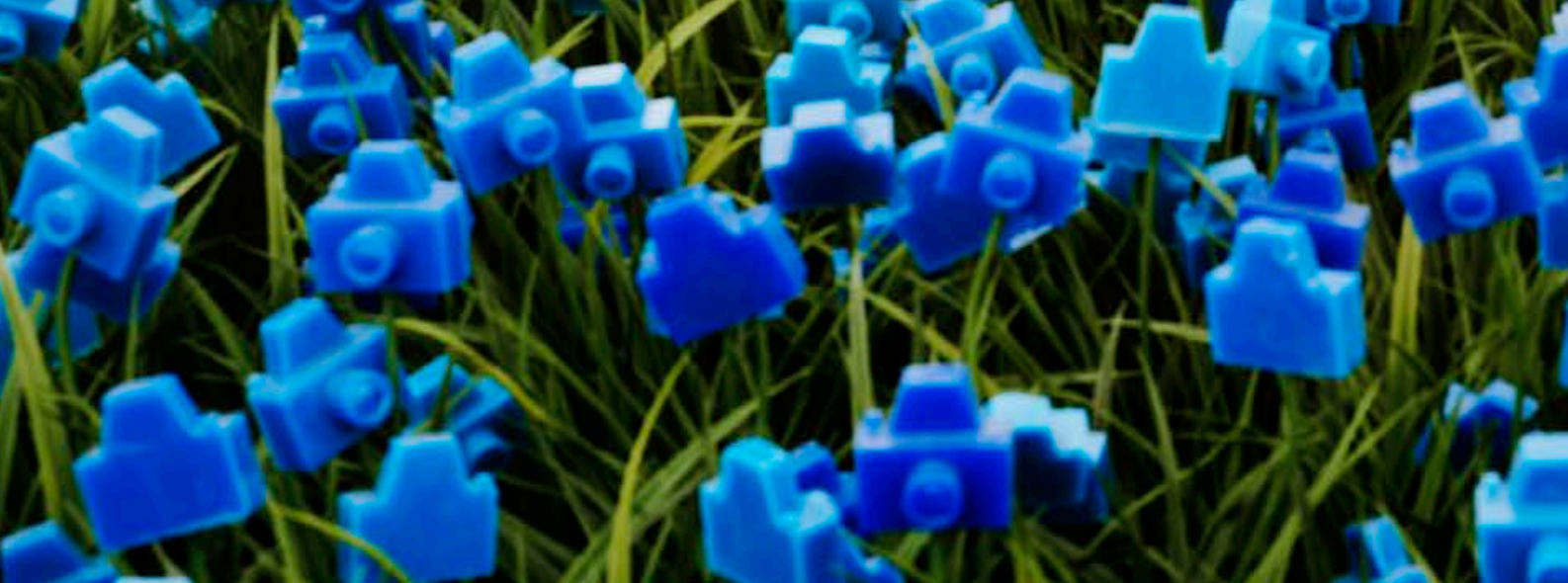

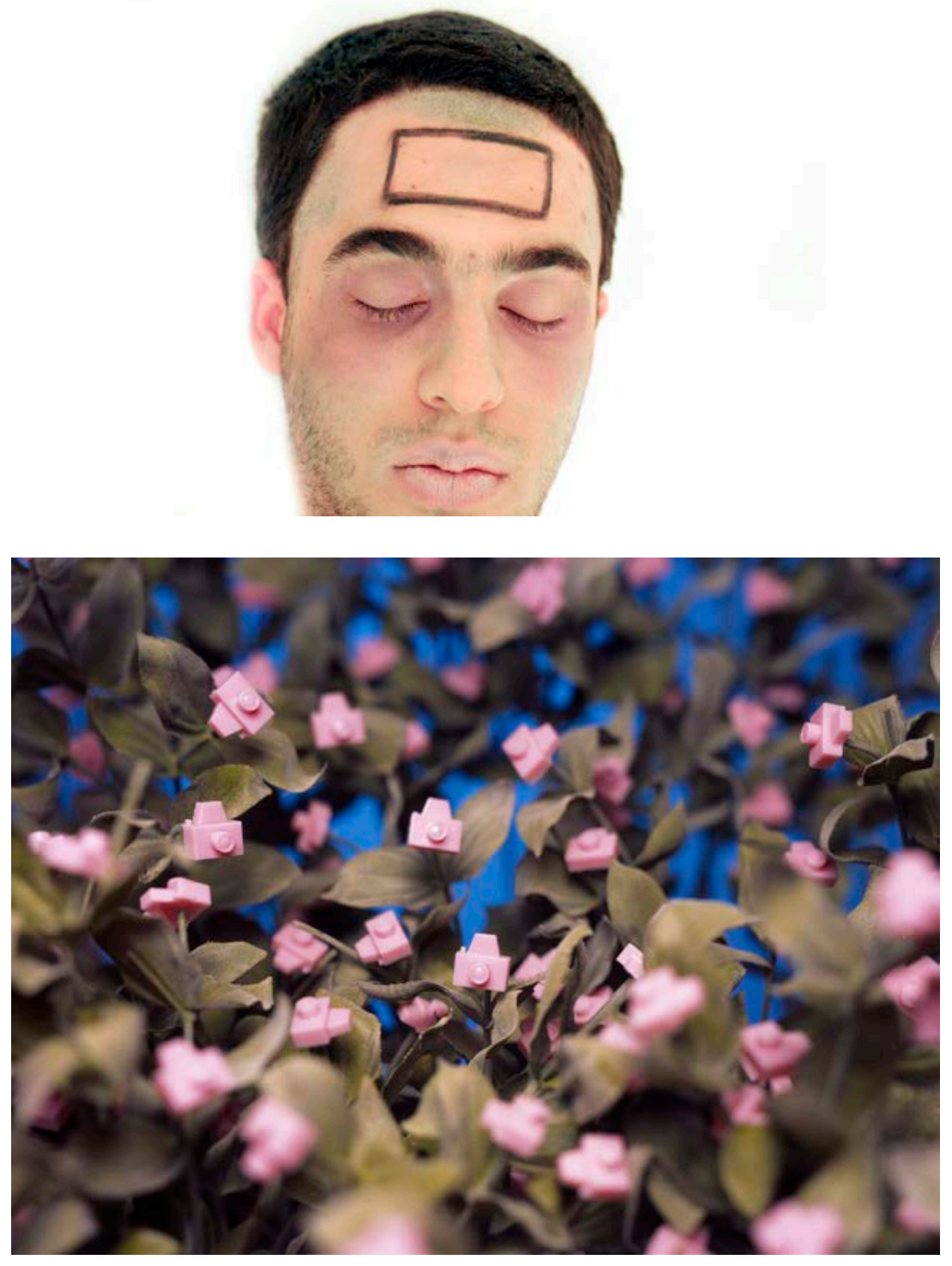
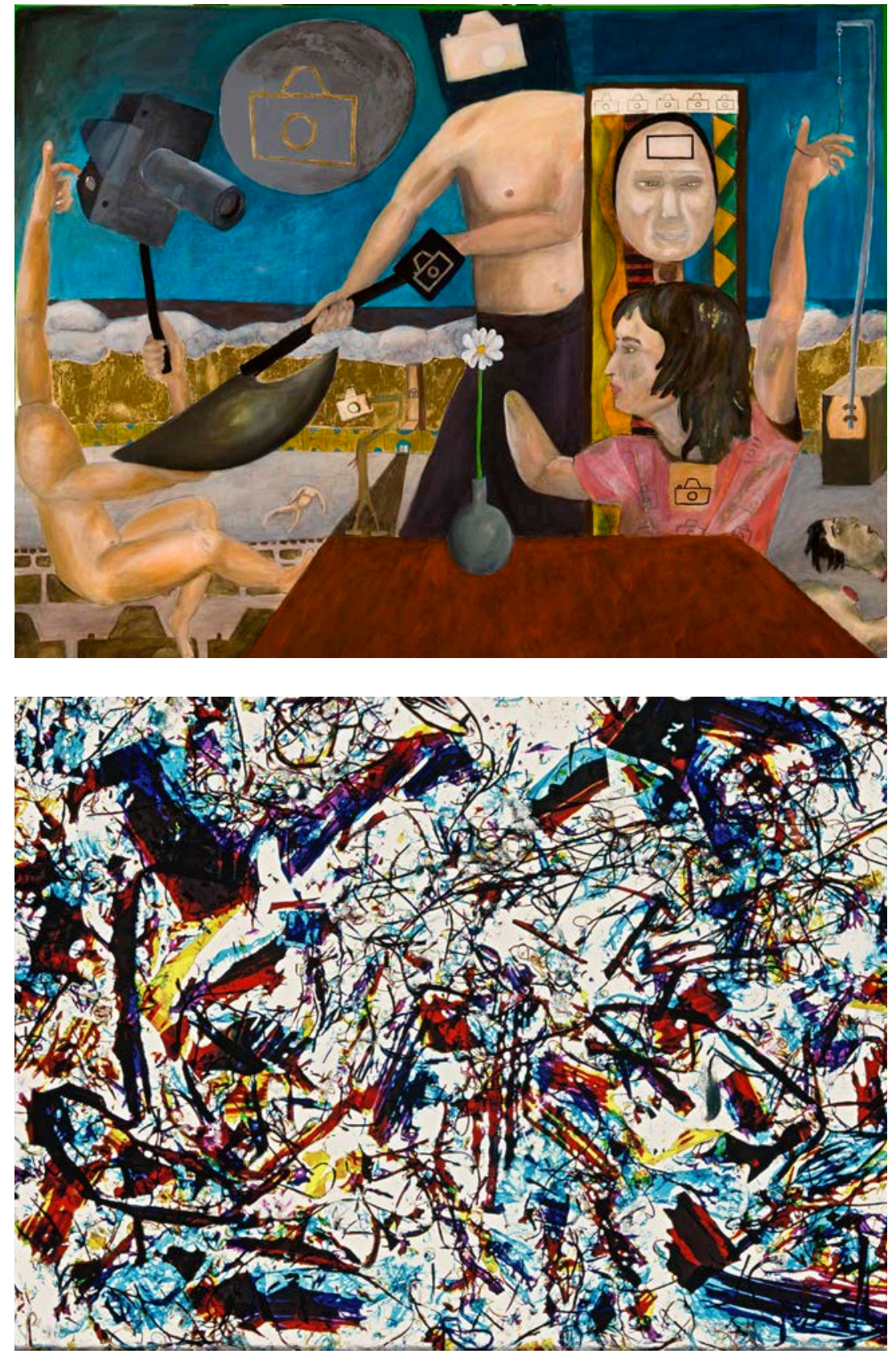

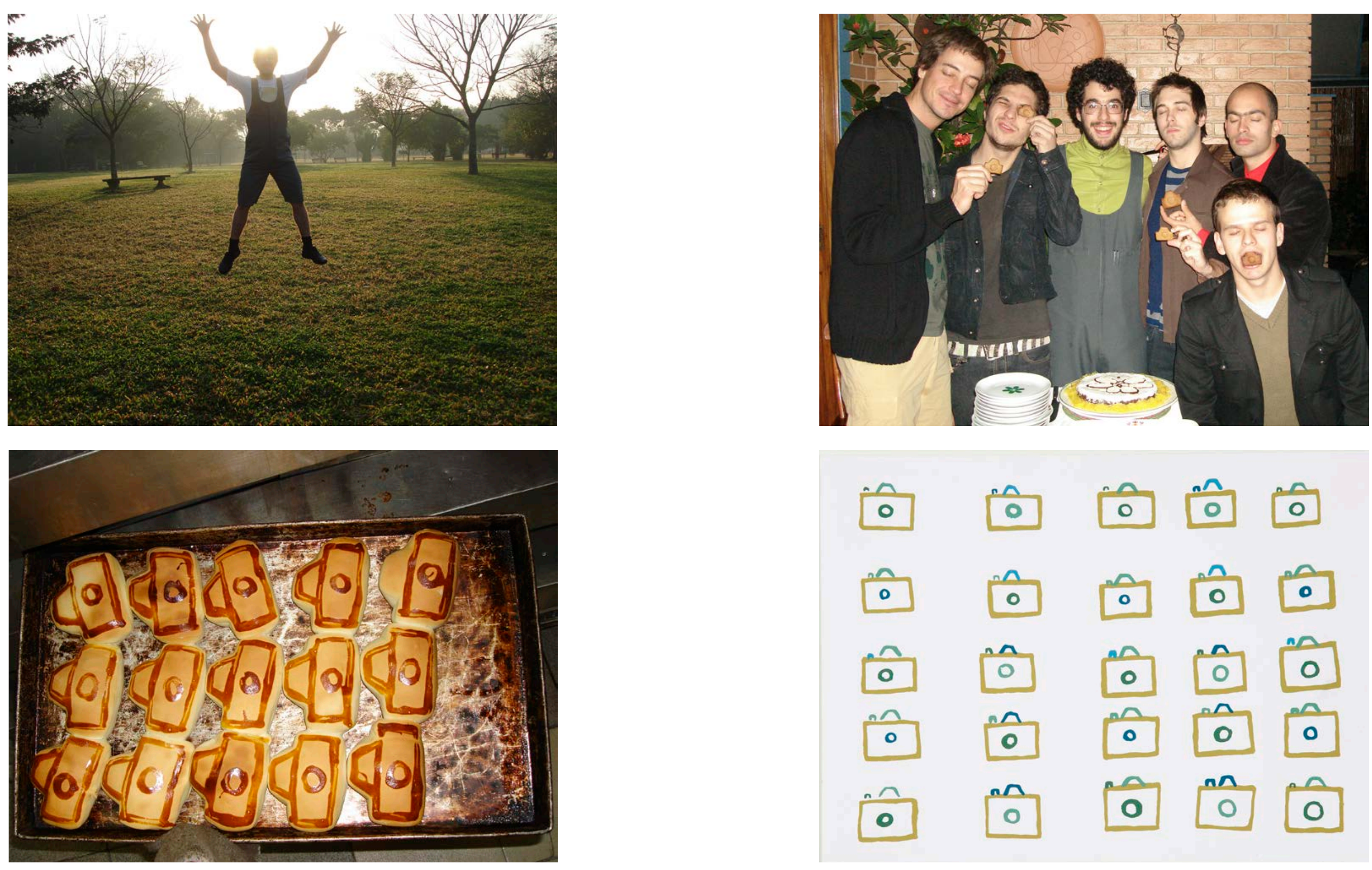

\begin{tabular}{|c|c|c|c|c|}
\hline 0 & م & م & ח & 0 \\
\hline ח & $n$ & & n & مص \\
\hline 0 & 0 & 0 & 0 & 0 \\
\hline n & $n$ & ח & $n$ & ח \\
\hline 0 & 0 & 0 & 0 & 0 \\
\hline$n$ & $n$ & מ & n & 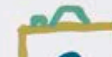 \\
\hline 0 & 0 & 0 & 0 & 0 \\
\hline ก & n & $n$ & nn & n \\
\hline 0 & 0 & 0 & 0 & 0 \\
\hline
\end{tabular}



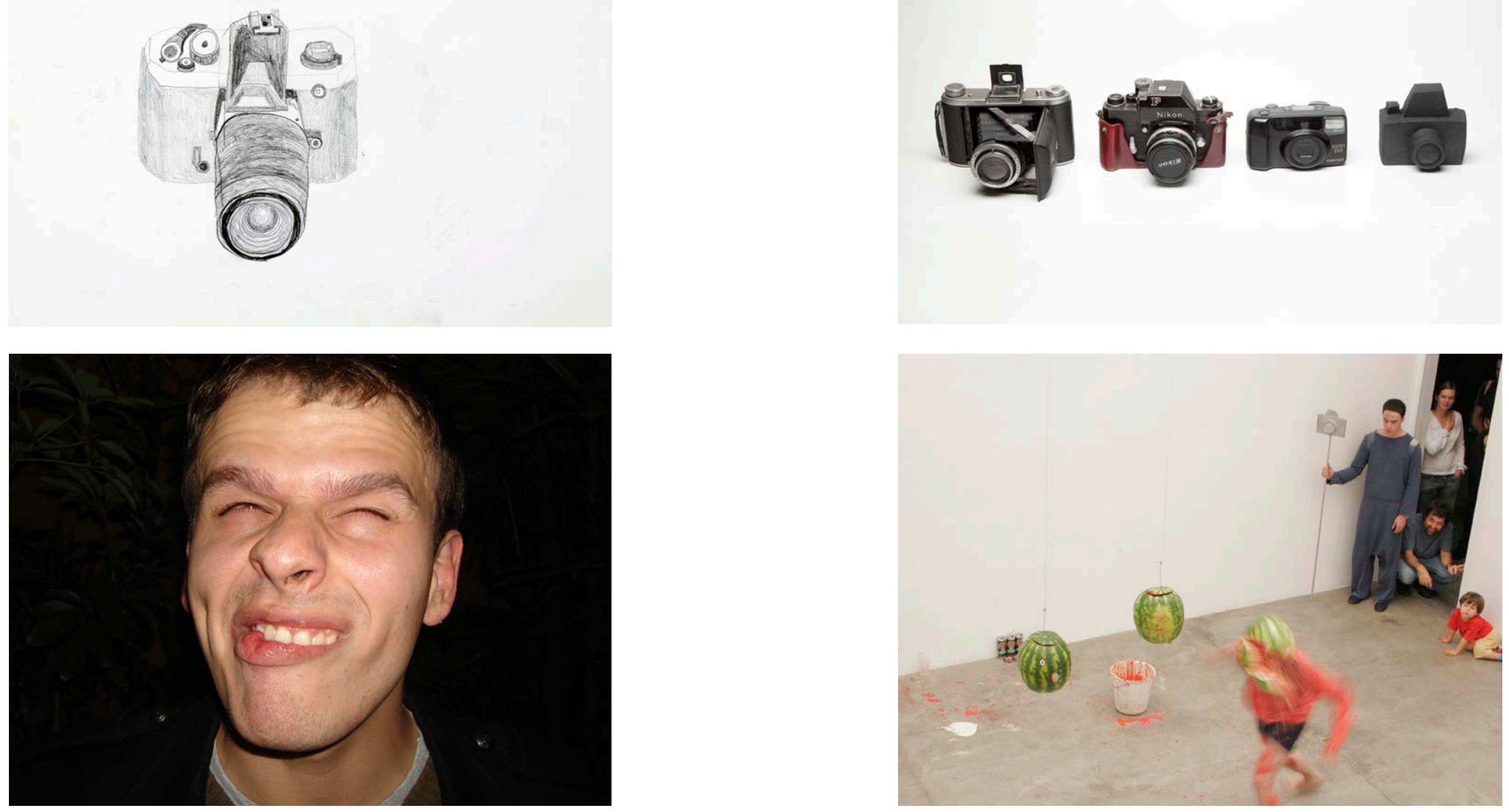

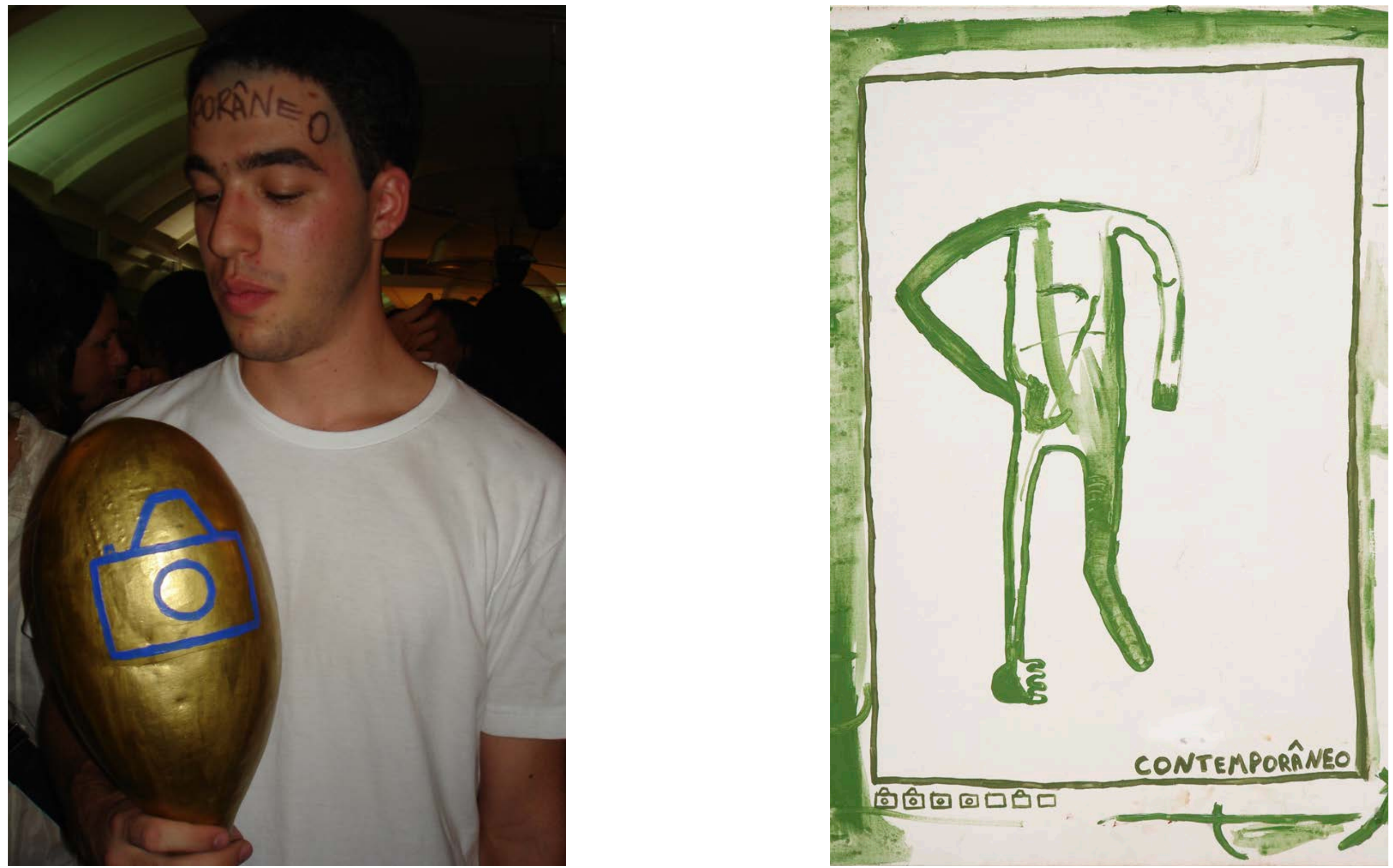

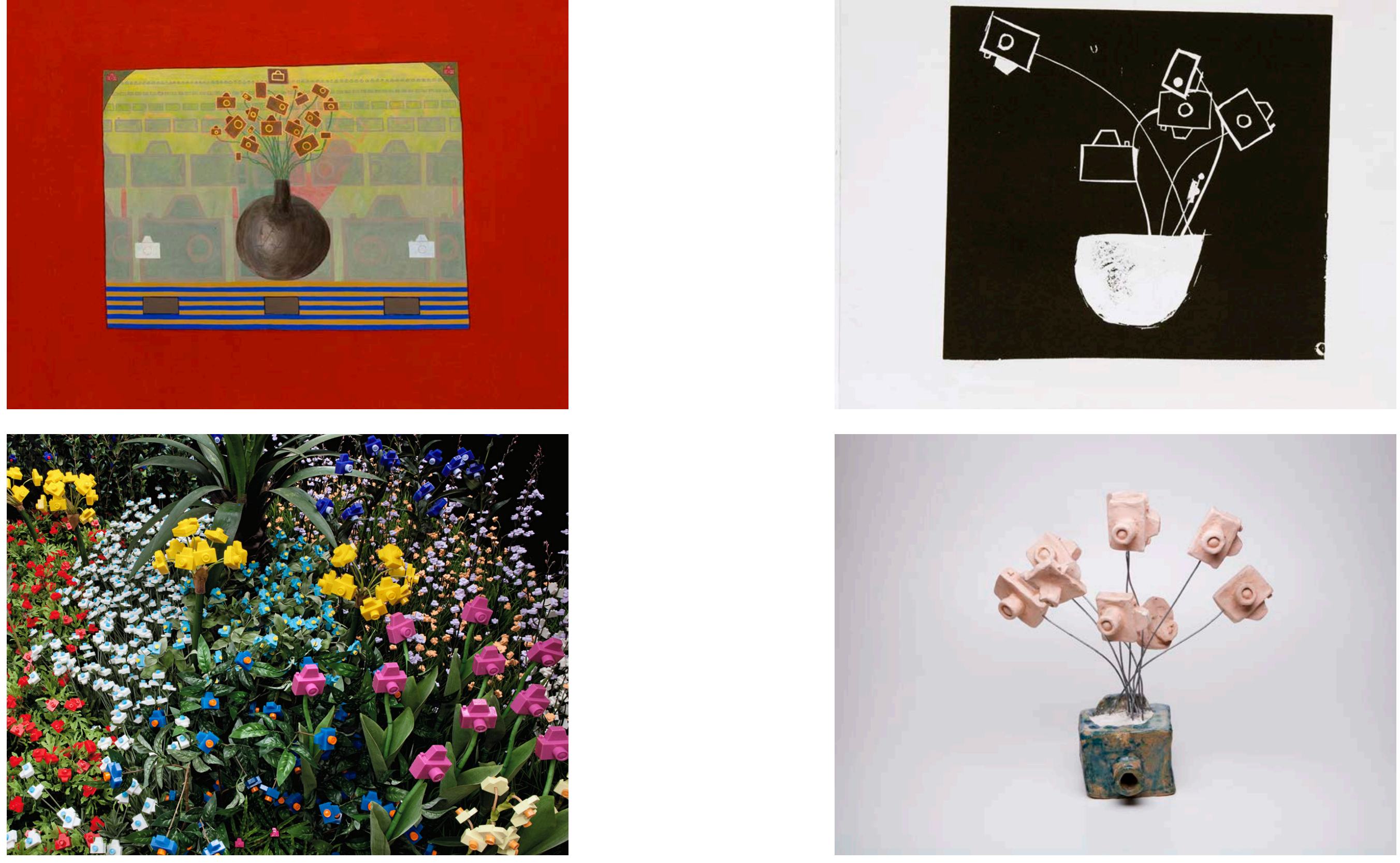
REFERÊNCIAS

Atlas Mnemosine. Disponível em: < http://www.aisthesisonline. it/2010/2-2010/i-warburg/>. Acesso em:_05 jun. 2013.

BARTHES, Roland. A Câmera Clara. Rio de Janeiro: Nova Fronteira, 1984.

CAUQUELIN, Anne. Arte Contemporânea: uma introdução. São Paulo: Martins Fontes: 2005

DUBOIS, Philippe. O Ato Fotográfico. Campinas: Papirus, [1990] 1993

FELICIANO, André. Arte Florescentista. São Paulo: Altana, 2008.

FELICIANO, André. Literatura Florescentista: Dois Amantes que se Amam mas não se Mexem. São Paulo: Altana, 2008.

FELICIANO, André. Educação Florescentista. São Paulo: Edição do Autor, 2009.

FELICIANO, André (org). Cultura Florescentista. São Paulo: Edição do Autor, 2010.

FLUSSER, Vilém. A Filosofia da Caixa Preta: Estudos para uma Futura Filosofia da Fotografia. São Paulo: Hucitec, [1983] 1985.

FLUSSER, Vilém. O Universo das Imagens Técnicas: Elogio da superficialidade. São Paulo: Annablume, 2008.

FLUSSER, Vilém. Natural:mente. São Paulo: Annablume, 2011.

GREEMBERG, Clement. Clement Greemberg e o debate Crítico. Rio de Janeiro: Jorge Zahar, 2001.
KRAUSS, Rosalind. O Fotográfico. Barcelona: Editorial Gustavo Gili, 2002.

MALRAUX, André. O Museu Imaginário. Lisboa: Edições 70, [1965] 2000.

MERLEAU-PONTY, Maurice. A Natureza. São Paulo: Martins Fontes, 2006.

RIBON, Michel. A Arte e A Natureza. Campinas: Papirus, 1991.

SONTAG, Susan. Ensaios sobre a Fotografia. Rio de Janeiro: Ed. Arbor, [1977] 1983.

TASSINARI, Alberto. O Espaço Moderno. São Paulo, Cosac Naify, 2001.

FIGURAS

Acesso em: 05 jun. 2013 às 12 horas.

Figura 1: Disponível em: <http://www.engramma.it/eOS2/ atlante $/$ index.php?id_tavola $=1048>$

Figura 2: Disponível em: <http://0.tqn.com/d/goparis/1/0/ m/A/-/-/GalerieApollon.jpg $>$

Figura 3: Disponível em: <http:/ / trufflehunting.files.wordpress com/2012/02/gagosian12-01-12_shot_07.jpg>

Figura 4: Disponível em: <http:/ / coursecontent.westhillscollege.com/Art\%20Images/CD_04/DU2500/details/MK01501P. htm $>$

Figura 5: Disponível em: < http:/ /www.wikipaintings.org/en/ joseph-beuys/i-like-america-and-america-likes-me $>$ 
blog.natureza.art.br 